General Technical

\title{
Columbia River Basin
}

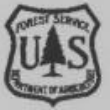

Evelyn L. Bull, Catherine G. Parks, and Torolf R. Torgersen

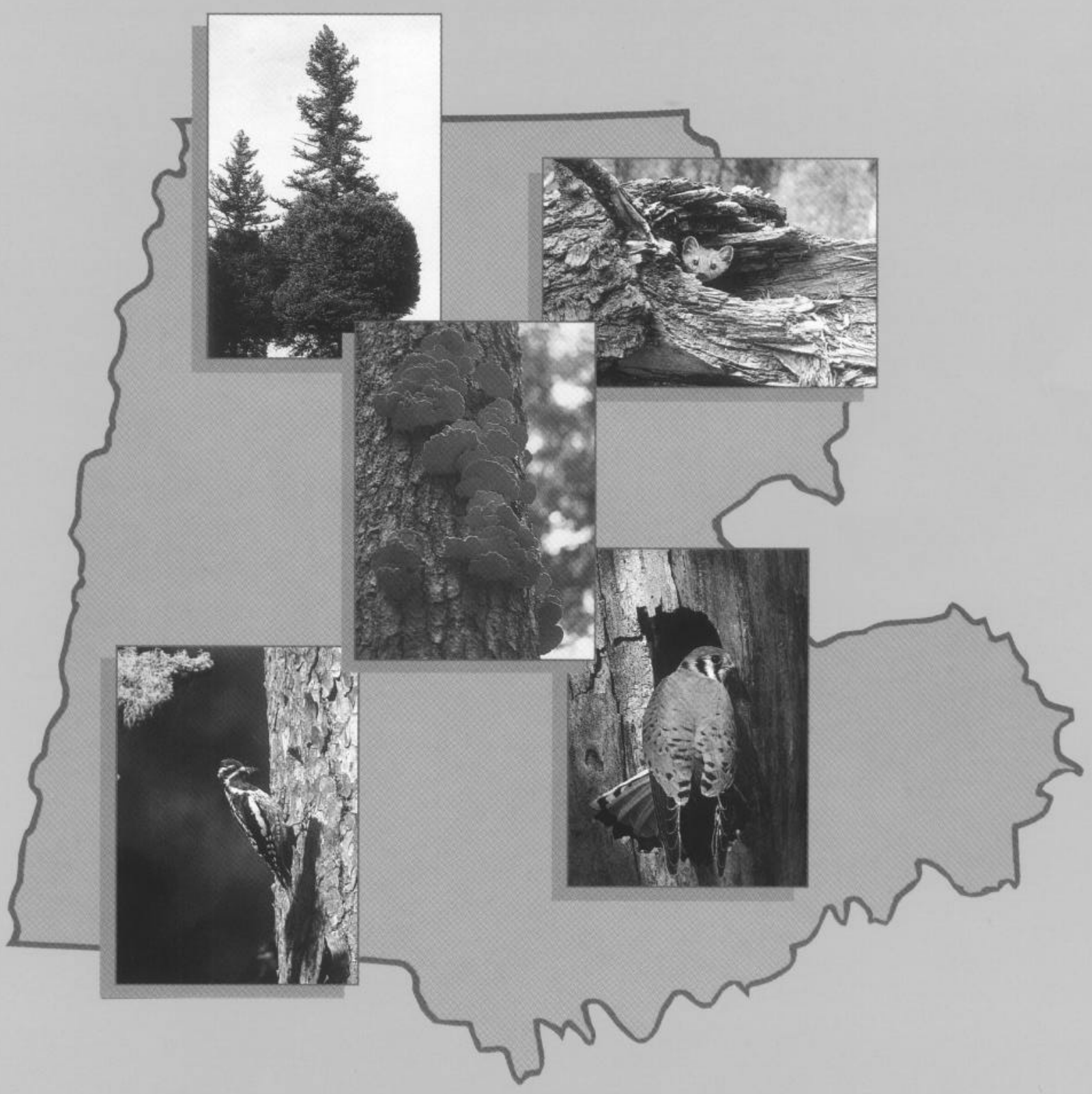




\section{AUTHORS}

EVELYN L. BULL is a research wildlife biologist, CATHERINE G. PARKS is a research plant pathologist, and TOROLF R. TORGERSEN is a research entomologist, Pacific Northwest Research Station, Forestry and Range Sciences Laboratory, 1401 Gekeler Lane, La Grande, Oregon 97850-3399. 


\section{Trees and Logs Important to Wildlife in the Interior Columbia River Basin}

Evelyn L. Bull, Catherine G. Parks, and Torolf R. Torgersen

Companion to General Technical Report PNW-GTR-390

Published by:

U.S. Department of Agriculture, Forest Service

Pacific Northwest Research Station

General Technical Report PNW-GTR-391

May 1997 


\section{ABSTRACT}

Bull, Evelyn L.; Parks, Catherine G.; Torgersen, Torolf R. 1997. Trees and logs important to wildlife in the interior Columbia River basin. Gen. Tech. Rep. PNW-GTR-391. Portland, OR: U.S. Department of Agriculture, Forest Service, Pacific Northwest Research Station. 55 p.

This publication provides qualitative and quantitative information on five distinct structures: living trees with decayed parts, trees with hollow chambers, trees with brooms, dead trees, and logs. Information is provided on the value of these structures to wildlife, the decay or infection processes involved in the formation of these structures, and the principles to consider for selecting the best structures to retain.

Keywords: Broom rust, cavity nesters, decay fungi, dwarf mistletoe, Elytroderma, forest management, habitat monitoring, hollow trees, interior Columbia River basin, logs, old-growth forests, snags, wildlife, wood decay. 
1 INTRODUCTION

3 LIVING TREES WITH DECAY

3 Ecological Processes and Functions

5 Decay Process

5 Selecting Trees

6 Review

9 HOLLOW TREES

9 Ecological Processes and Functions

9 Decay Process

10 Selecting Hollow Trees

10 Review

13 BROOMED TREES

13 Dwarf Mistletoes

17 Broom Rusts

17 Elytroderma Disease

18 Review

21 DEAD TREES

21 Ecological Processes and Functions

23 Decay Process

23 Selecting Snags

29 Snag Longevity

30 Sampling Techniques

31 Creating Wildlife Trees

31 Review

35 LOGS

35 Ecological Processes and Functions

36 Decay Process

38 The Log Resource

40 Review

43 CONCLUSIONS

44 ACKNOWLEDGMENTS

45 REFERENCES

53 Appendix A: Data Form for Monitoring Created Snags

54 Appendix B: Data Form for Surveying Logs

55 Appendix C: Methods for Log Inventories 
This page left blank intentionally 


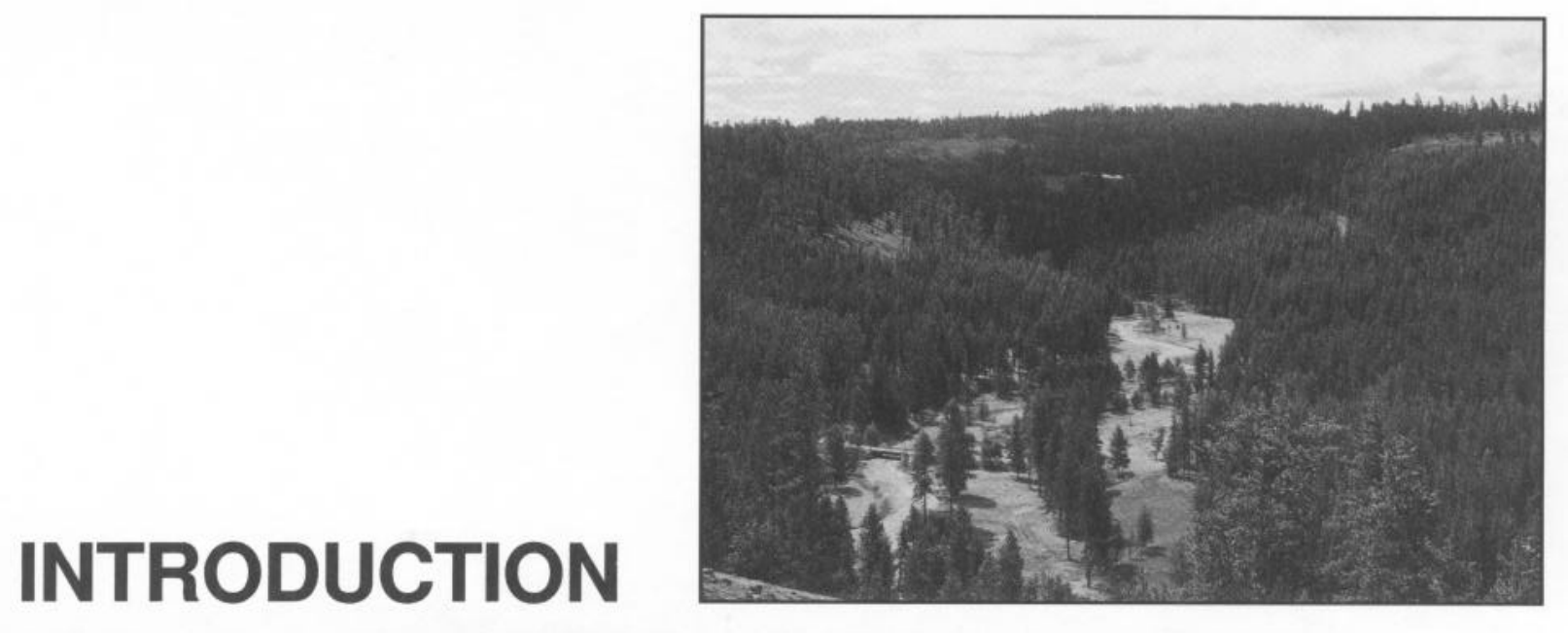

More than 80 species of birds, mammals, reptiles, and amphibians use living trees with decay, trees with brooms, hollow trees, snags, and logs in the interior Columbia River basin. Animals use these structures for foraging, nesting, denning, roosting, and resting. Most notable of these woodusing wildlife species are the primary cavity nesters, the woodpeckers and nuthatches, that excavate nest cavities in decayed wood in standing trees. Their vacated cavities are subsequently used by many other birds and mammals.

About 25 percent of the bird species nesting in the northern Rocky Mountain forests are cavity nesters (McClelland and others 1979). Many of the primary and secondary cavitynesting birds eat forest insects and thus play an important role in regulating their populations. Machmer and Steeger (1995) provide a thorough review of the effect these birds have in reducing numbers of tree-feeding insects.

Tree decay is an important ecological process affecting wildlife habitat. Once begun, the decay process can take hundreds of years as a tree dies, falls to the ground, and decomposes into the forest floor. As it decays, the tree supports many different wildlife groups that use it for foraging substrate, for nesting, and for shelter. The group of wood decomposers is diverse. It includes many arthropods, but in this publication, we focus on decay fungi as the primary organisms in decay. Decay fungi are an essential resource to forest ecosystems in storing and retaining nutrients and in soil development.

This publication provides managers with a description of the ecological processes that create wildlife trees, snags, and logs. It provides qualitative and quantitative information on five distinct structures: living trees with decay (such as internal decay), hollow trees, trees with brooms (misshapen branches), dead trees (snags), and down woody material (logs). We describe the value of these structures to wildlife, the decay or infection processes that produce each type of structure, principles to help in selecting the best structures to retain, and management implications. Although this document cannot prescribe the amount of landscape to manage for a particular species or a specific, desired population size, it does present information managers can use to make informed decisions regarding the conservation and enhancement of dead wood structures most valuable to wildlife. Forest management practices that fail to properly manage wood components may adversely affect wildlife, soil and stream quality, and forest ecosystem functions.

The information included here applies to coniferous forest lands in the interior Columbia River basin: the area east of the crest of the Cascade Range in Oregon and Washington, all of Idaho, and a portion of western Montana (fig. 1). Tree species characteristic of high-elevation forests, (such as whitebark pine [Pinus albicaulis], alpine larch [Larix lyallii], mountain hemlock [Tsuga mertensiana], and Pacific silver fir [Abies amabilis]) are excluded because they typically grow where active management for wildlife trees is seldom needed; these areas are seldom logged. Most of the tree species we deal with here are conifers, although black cottonwood (Populus trichocarpa), quaking aspen (Populus tremuloides), and paper birch (Betula papyrifera) are

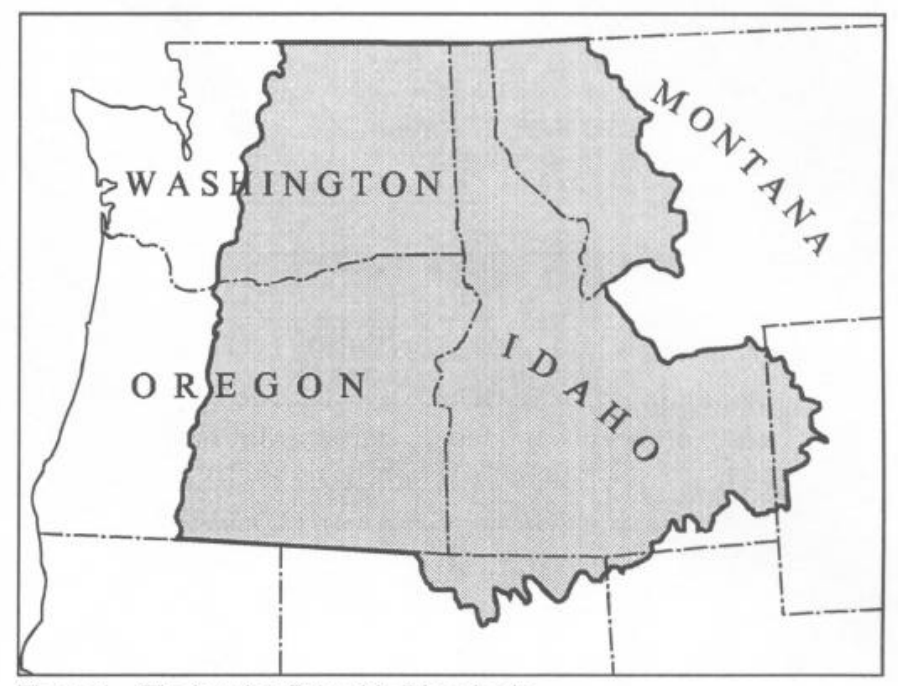

Figure 1-The interior Columbia River basin. 
included because they commonly occur in managed conifer forests.

Additional information on how to distinguish among different species of snags and logs is provided in a companion document (Parks and others, in press) specifically designed to be used in the field.

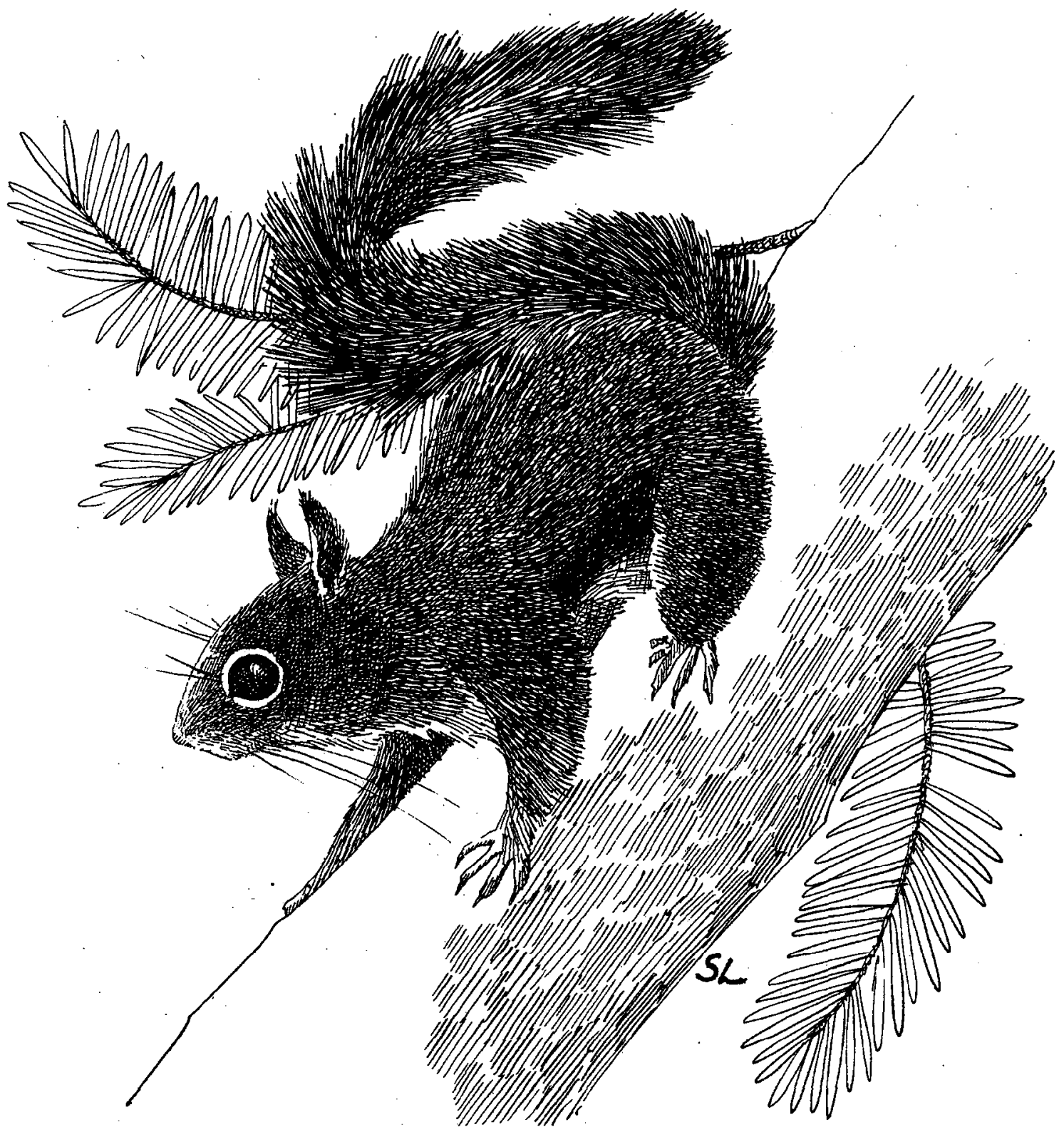




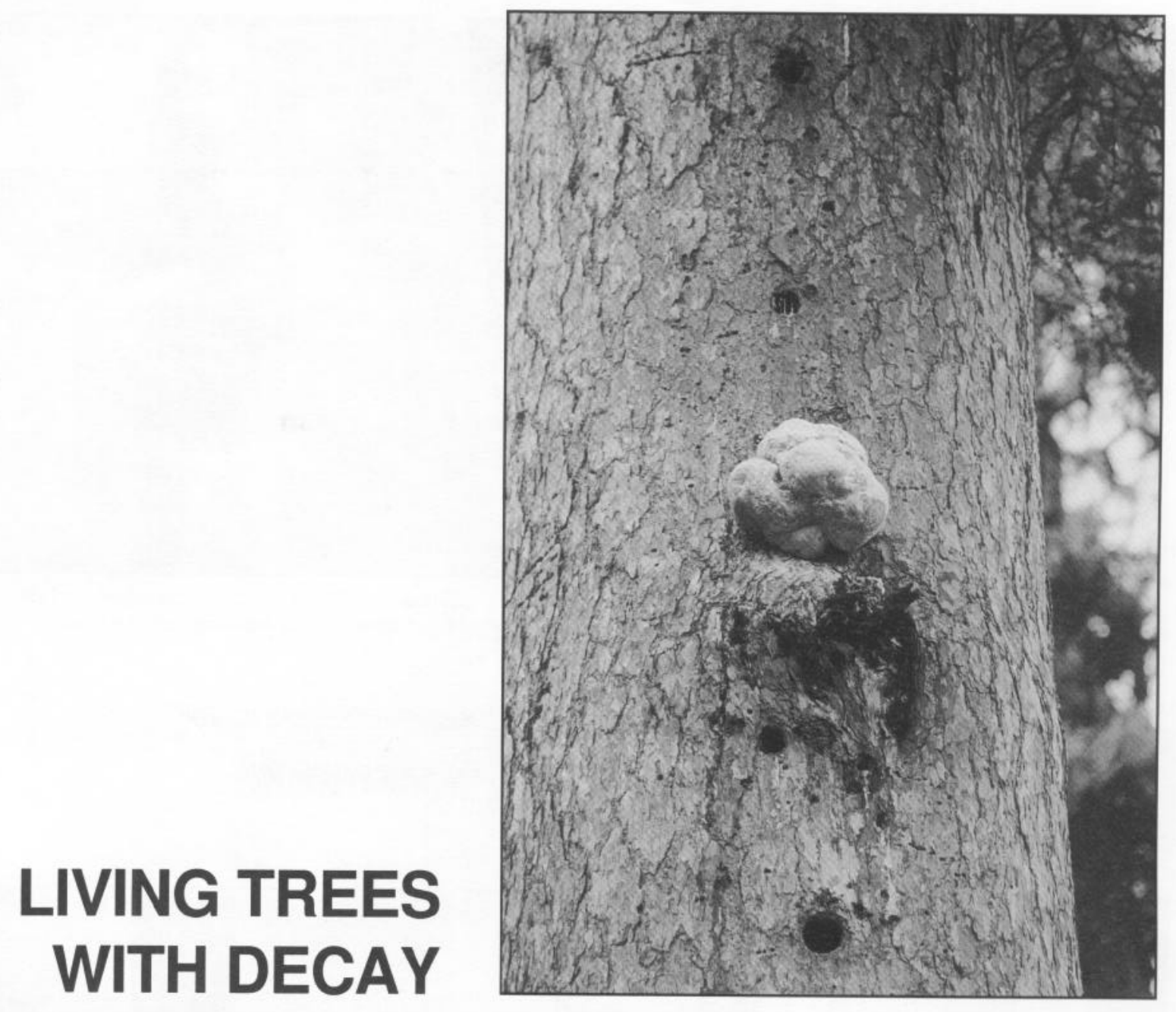

\section{Ecological Processes and Functions}

Although dead, standing trees (snags) are important to many wildlife species, living trees may contain decayed wood that allows them to function as snags. Living trees with an internal core or pockets of decay, top dieback, broken tops, or wounds all can serve as wildlife habitat (fig. 2). Living trees with dead portions typically stand longer than snags do, but the portion of the tree suitable for use by snag-dependent wildlife may be smaller than in a snag of the same size. Although hollow trees are alive, but with advanced internal decay, we treat them separately because they offer unique structural features and provide for specialized wildlife use.

Some woodpeckers select living trees with decayed heartwood because they can penetrate through the sound layer of sapwood and excavate the nest chamber in the softened heartwood (fig. 3) (McClelland and others 1979, Parks and others 1996a). Typically, the sapwood remains relatively intact for a long time, forming a shell surrounding the decaying heartwood, so the excavated interior may retain a desirable shape for nesting for many years. Woodpeckers commonly nesting in decayed wood in living trees in northeastern Oregon include the Williamson's (Sphyrapicus thyroideus) and rednaped sapsuckers (S. nuchalis) and black-backed woodpeckers (Picoides arcticus) (Bull 1986). Living trees with heart rot are a required habitat component for the red-cockaded woodpecker ( $P$. borealis), a widely known and rare species from the Southern United States. This woodpecker selects pines older than 80 years that are infected with the heart-rot fungus Phellinus pini to excavate its cavities (Conner and Locke 1982, Hooper and others 1991).

Trees with large dead branches or dead tops (fig. 4) provide a distinctive habitat in the living forest canopy (Parks and Shaw 1996). Cavity nesters such as the whiteheaded woodpeckers (Picoides albolarvatus) commonly roost in dead tops of living trees (Dixon 1995). Dead tops provide good resonating towers from which drumming woodpeckers proclaim their territorial boundaries and provide hunting perches for raptors. Living trees with broken tops also may provide nesting platforms for raptors.

Any wounding or scarring of the living tree can result in localized dead, decaying wood (fig. 5). Decaying wood, particularly at the base of the living tree, is often colonized by ants. Pileated woodpeckers (Dryocopus pileatus) forage 

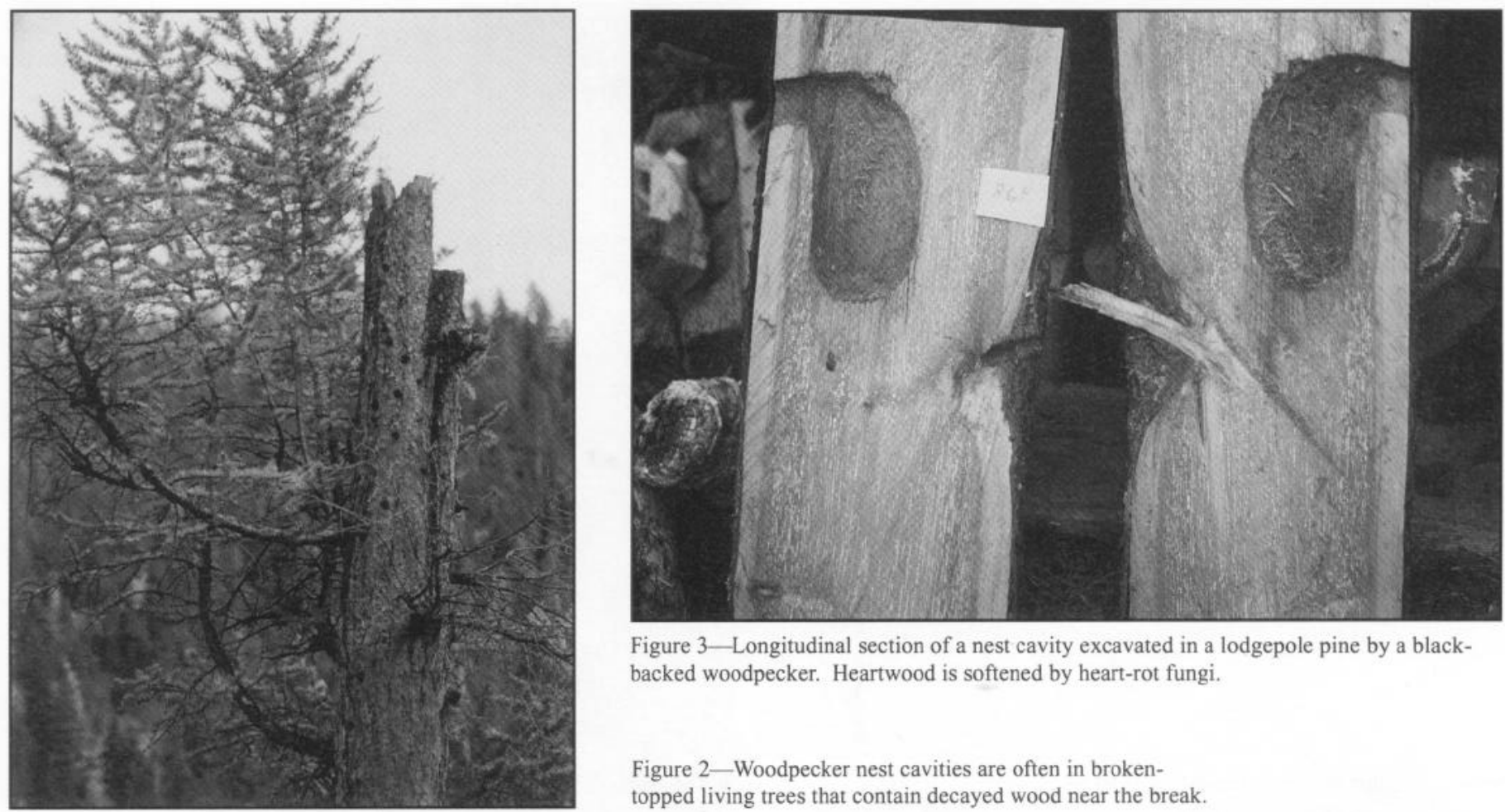

Figure 3 - Longitudinal section of a nest cavity excavated in a lodgepole pine by a blackbacked woodpecker. Heartwood is softened by heart-rot fungi.

Figure 2-Woodpecker nest cavities are often in broken-

topped living trees that contain decayed wood near the break.

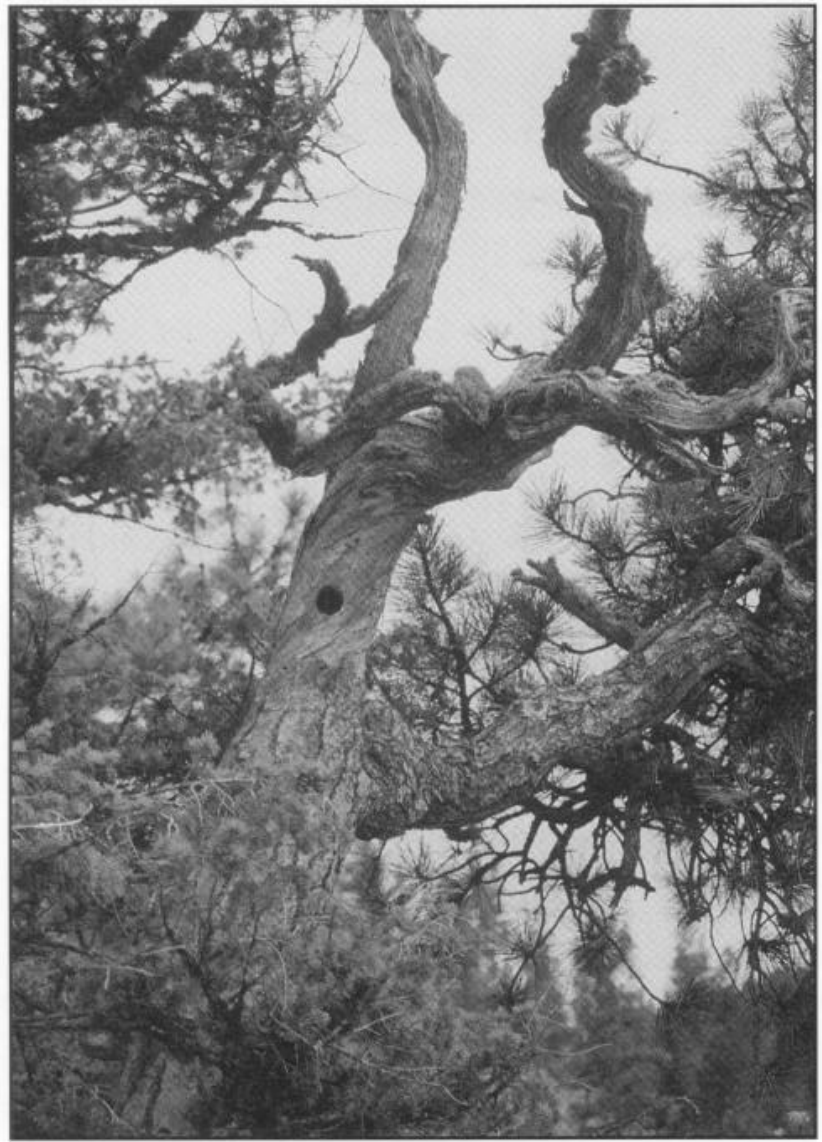

Figure 4 Woodpecker nest cavity excavated in the dead top of a living ponderosa pine.

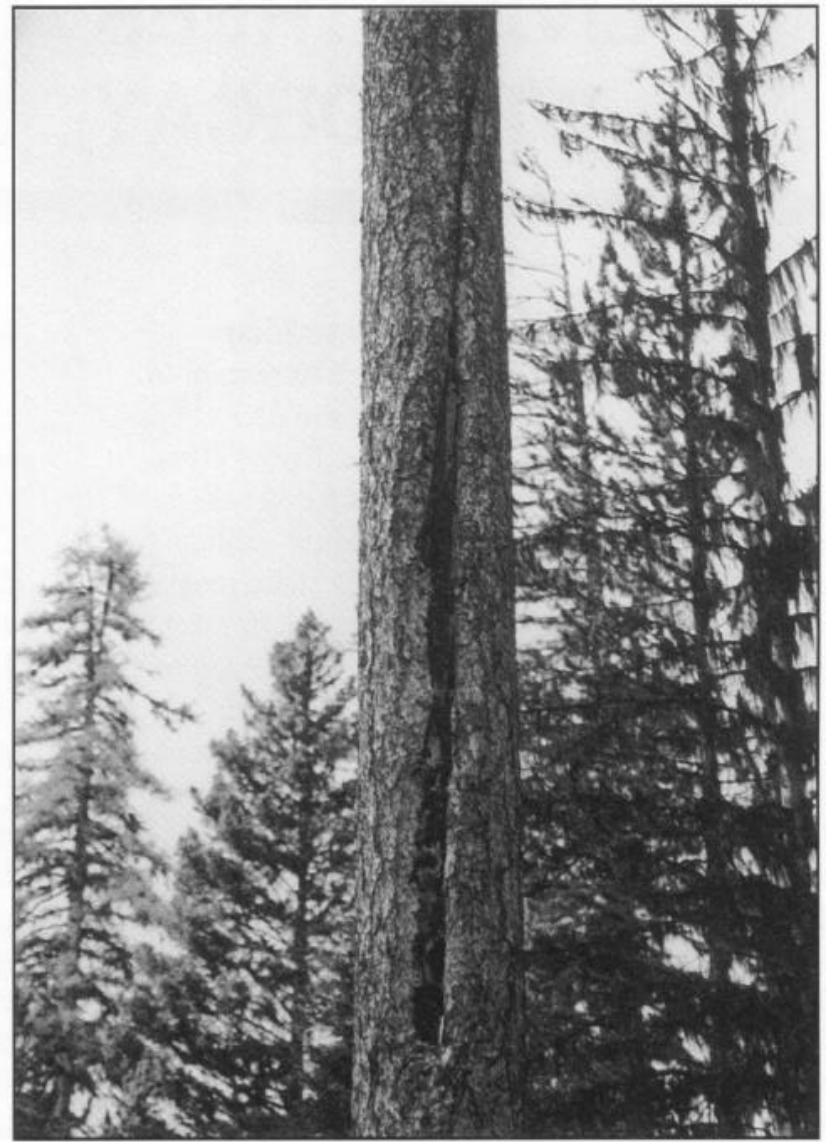

Figure 5-Scars caused by lightning or other injuries are frequently used by woodpeckers for foraging. 
on ants at these sites, as documented in a study that found 18 percent of foraging by these birds is in living trees (Bull and Holthausen 1993).

\section{Decay Process}

Wood decay is caused by fungi that decompose the cell wall. Wood decayers can be separated based on whether a fungus survives primarily in the heartwood of living trees or primarily in dead trees or in logs. Generally, the decay fungi in upper stems of living trees are heart-rot fungi (Manion 1981). The decay fungi of dead trees and logs are saprophytic fungi. Although every tree species is susceptible to at least one heart-rot fungus, few fungi can cause heart-rot in living trees. Conversely, many decay fungi can survive on dead branches of living trees, or inhabit a tree once it dies.

Heart-rot fungi are spread by airborne spores produced by fruiting bodies--either conks or mushrooms. The spores colonize freshly exposed wood at wounds or dead branch stubs. Although spores of heart-rot fungi are abundant in forest stands of all ages, old-growth stands have a much higher incidence of heart rot than do young stands (Manion 1981). The amount of heartwood is age related; older trees have a higher ratio of heartwood to sapwood than do younger trees (Gartner 1995). Decay in the heartwood may continue to increase in diameter as the trees grow and new layers of heartwood are added (Rayner and Boddy 1988).

Internal decay - Every living tree is composed of tissues that perform specific functions; decay in stems of living trees is closely linked to wood anatomy (fig. 6). The sapwood and heartwood offer different microhabitats and nutritional substrates for decomposer organisms. Typical heartwood has no living cells, is nonconductive, and develops in the oldest wood; sapwood has some living cells, is conductive, and occupies the outer sheath of wood around the stem, or the entire wood cylinder of a younger tree (Sperry 1995). In contrast to dead sapwood, which decays readily, live sapwood generally is resistant to decay partly because of its high moisture content and reduced aeration. Live sapwood may remain free of infection for many years, even when neighboring sapwood or heartwood is extensively decayed (Shain 1995).

The decay process of dead tops and other dead wood in the living tree, typically associated with dieback or wounding, is the same as in dead trees, described later in this report.

\section{Selecting Trees}

Decay in living trees is not always apparent, but certain characteristics can indicate its presence. Conks (fungal fruiting bodies) are evidence of heartwood decay, although fruiting bodies may not always be present in trees decayed by heart-rot fungi. Some fungi tend to fruit only on fallen or cut trees and produce fruiting bodies on living trees only rarely. Generally, fruiting bodies of heart-rot fungi are found close to branch stubs or living branches and are few compared to the numbers of fruiting bodies of sapwood-decaying or saprophytic fungi, which may be found in groups over the whole stem surface of dead trees and logs.
Most tree species are susceptible to only a few heart-rot fungi. Ponderosa pine (Pinus ponderosa) is commonly associated with red ring rot caused by Phellinus pini (fig. 7). This fungus also may be found fruiting on lodgepole pine (Pinus contorta), western white pine ( $P$. monticola), western larch (Larix occidentalis), and Douglas-fir (Pseudotsuga menziesii) in some areas. Internal decay in grand fir (Abies grandis), subalpine fir ( $A$. lasiocarpa), and mountain hemlock often is indicated by conks of the Indian paint fungus (Echinodontium tinctorium) (figs. 8 and 9). Indian paint fungus causes a characteristic stringy decay that can involve the entire tree trunk (fig. 10). Internal decay of western larch and occasionally ponderosa pine is indicated by the fruiting body of the brown trunk rot caused by Fomitopsis officinalis (fig. 11). Internal decay in quaking aspen and paper birch is most often associated with Phellinus tremulae (fig. 12) and $P$. igniarius, respectively. Depending on climate, elevation, and other local conditions, fruiting bodies may be occasional or abundant. Hepting (1971) provides a complete list of the decay fungi associated with forest trees in the United States.

In the absence of fruiting bodies, obvious wounds are the next best indicators of internal decay in living trees. Wounding is fundamental to decay because germinating fungal spores cannot penetrate intact bark or living sapwood. Spores usually must land on exposed dead wood directly connected with the heartwood for decay to result (Boyce 1938). Broken tops, fire or lightning scars, or mechanical damage from harvest activities all may be good indicators of incipient or advanced internal decay. Sixty-two percent of 133 woodpecker nests in living trees had broken tops, and 17 percent had dead tops (McClelland and others 1979). All nests were associated with internal decay. Forty-four percent of the paper birch and 22 percent of the quaking aspen with nest cavities had fruiting bodies (McClelland 1977).

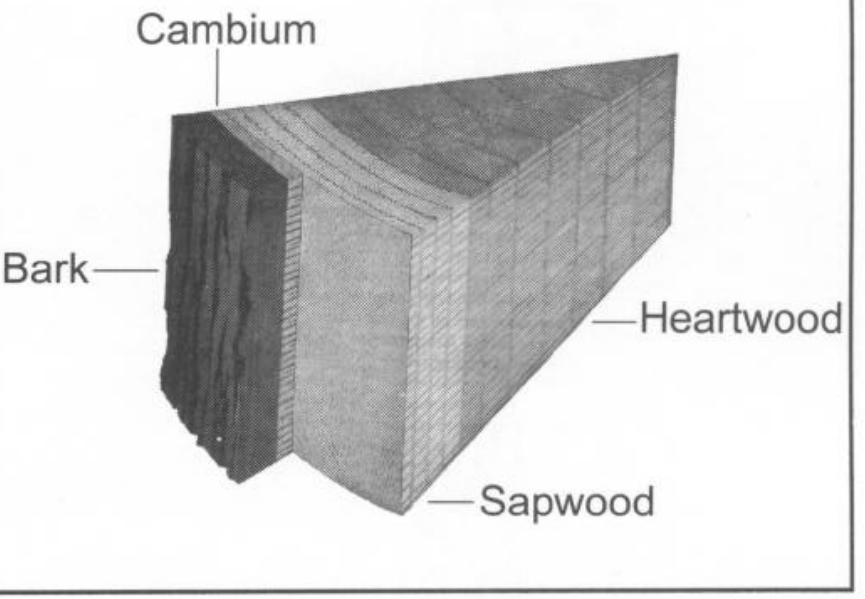

Figure 6-Wood anatomy showing the relation of sapwood and heartwood, each of which provides specialized substrates used by different microorganisms (modified from Brown and others 1949). 


\section{Review}

- A living tree may contain decayed wood that provides special wildlife use.

- Dead tops, large dead branches, broken tops, and wounded areas provide useful habitat in living trees.

- Living trees containing a decayed column of heartwood may stand longer than dead trees and can provide habitat for cavity nesters.

- Fungi that are specialized decomposers and decay the heartwood of living trees are heart-rot fungi. Fungi that are generalist decomposers are usually found only on dead parts of trees, snags, or logs and are saprophytic fungi.

- Conks indicate decay within the tree. Heart-rot fungi can be distinguished from saprophytic fungi by the appearance of their conks. In the absence of conks, broken tops, wounds, and scars also are indicators of decay in living trees.

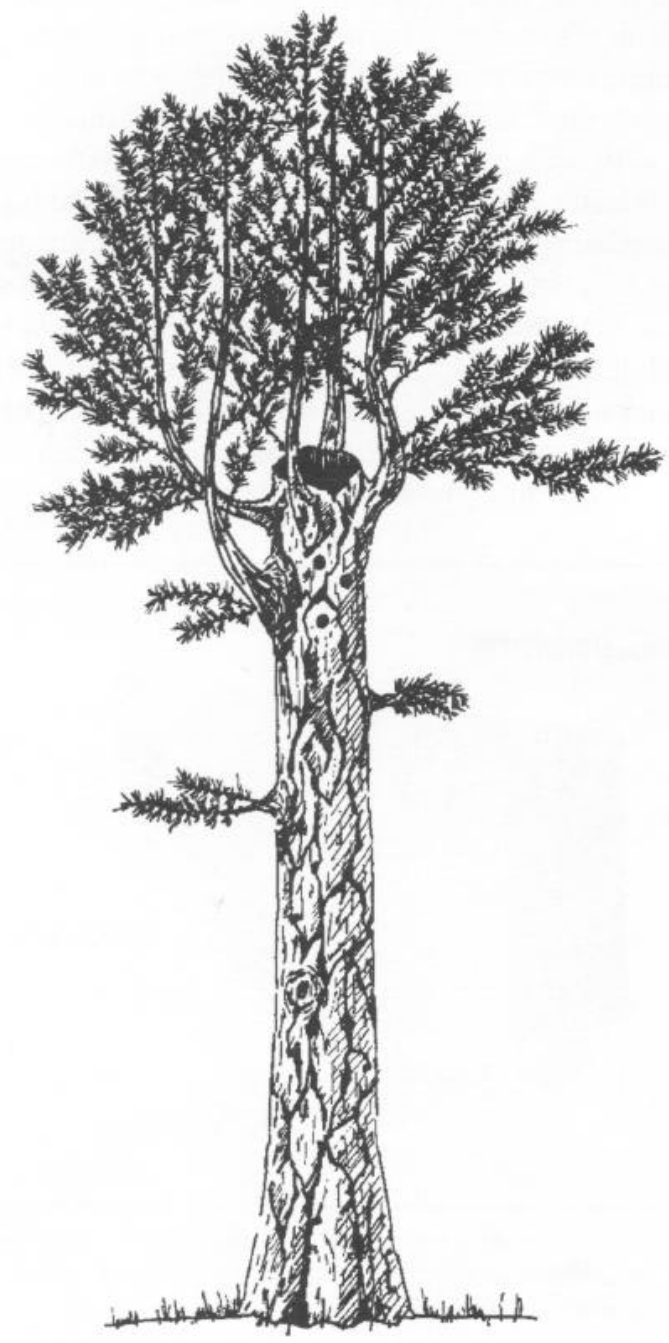

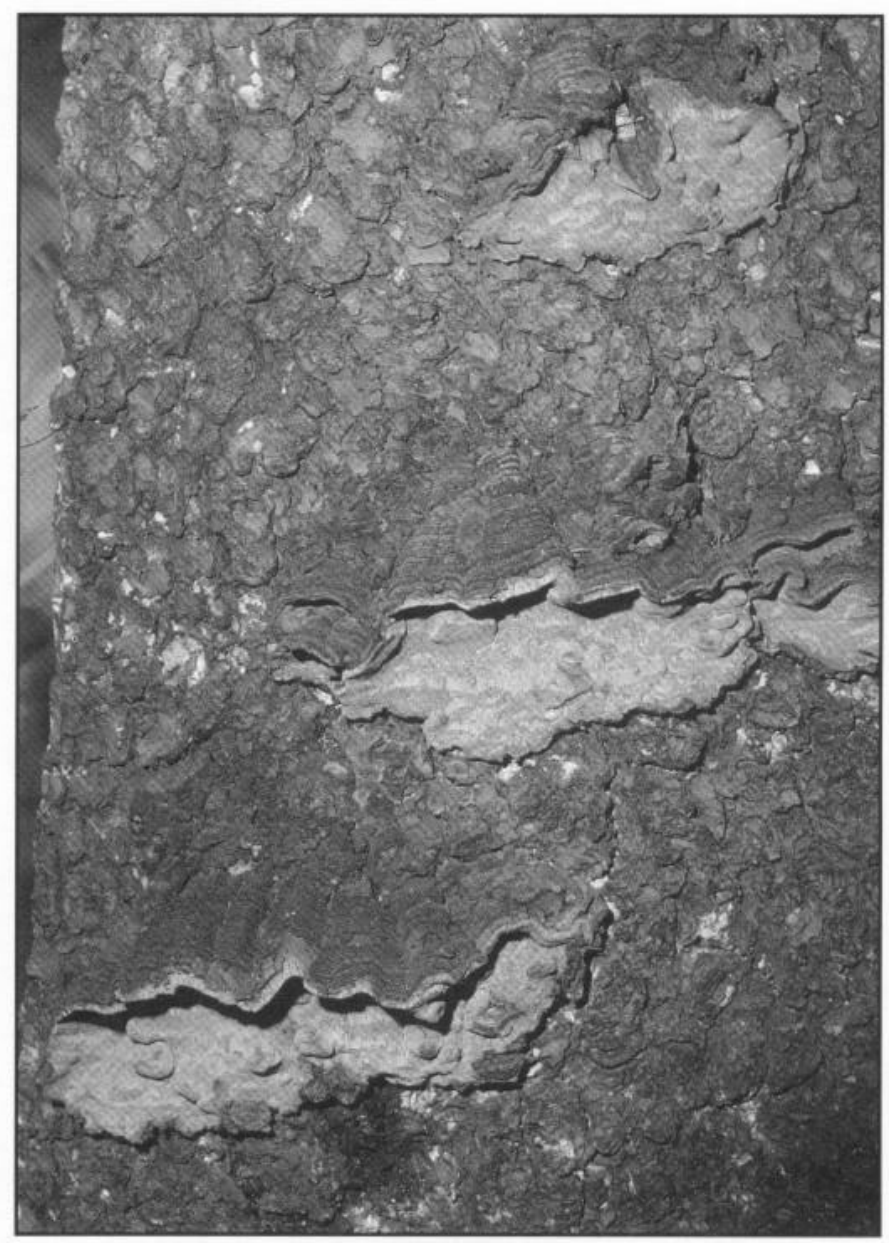

Figure 7-Fruiting bodies of red ring rot are hoof-shaped or flat on bark, dark brown on the upper surface, and cinnamon to tan on the lower surface and in the interior. This conk indicates internal decay, which is stringy with pronounced white pockets. Infected trees may have punk knots on the stem.

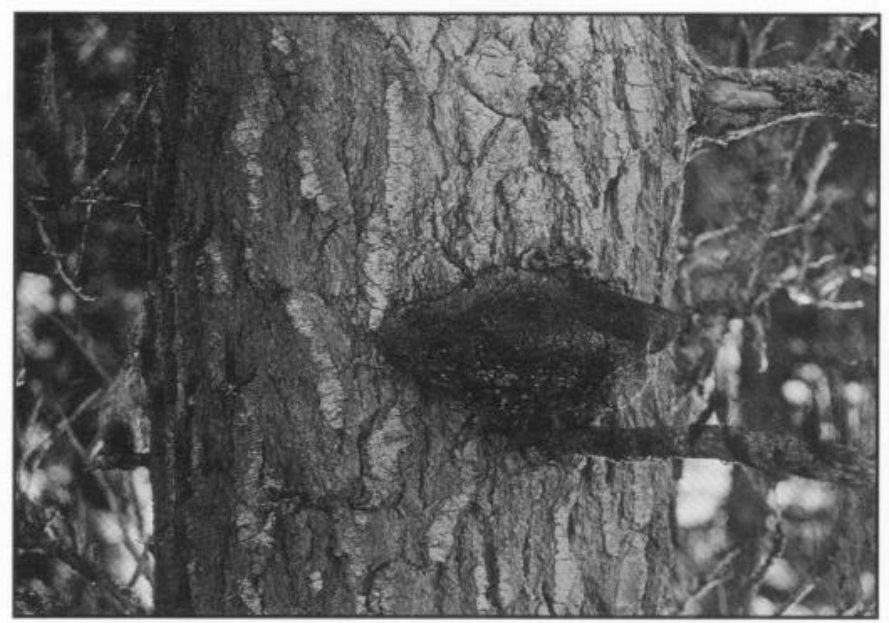

Figure 8-Fruiting bodies of Indian paint fungus are hoof-shaped and commonly located under a branch or branch stub. 


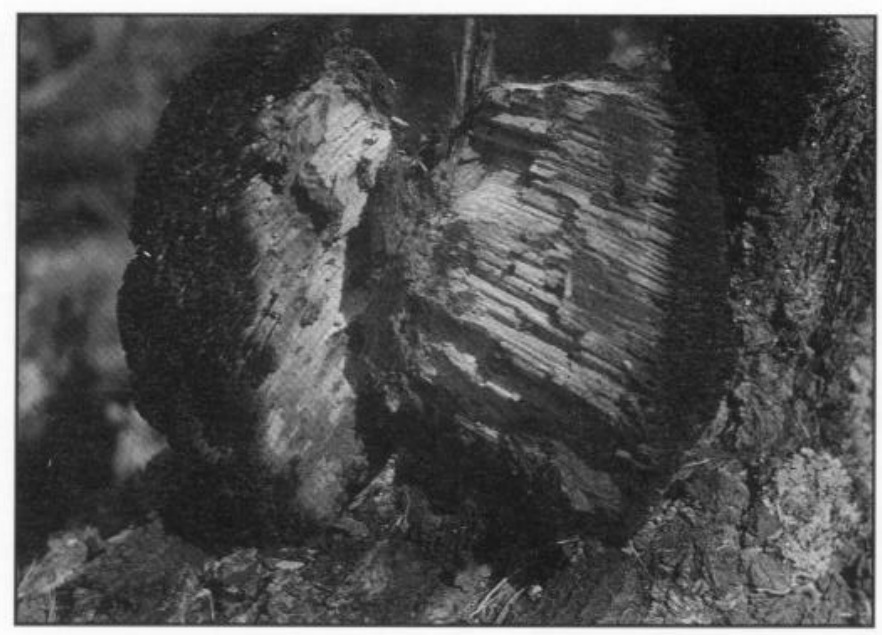

Figure $9-$ Conks of Indian paint fungus have a brown woody upper surface with teeth projecting downward on the lower surface. The interior is orange.

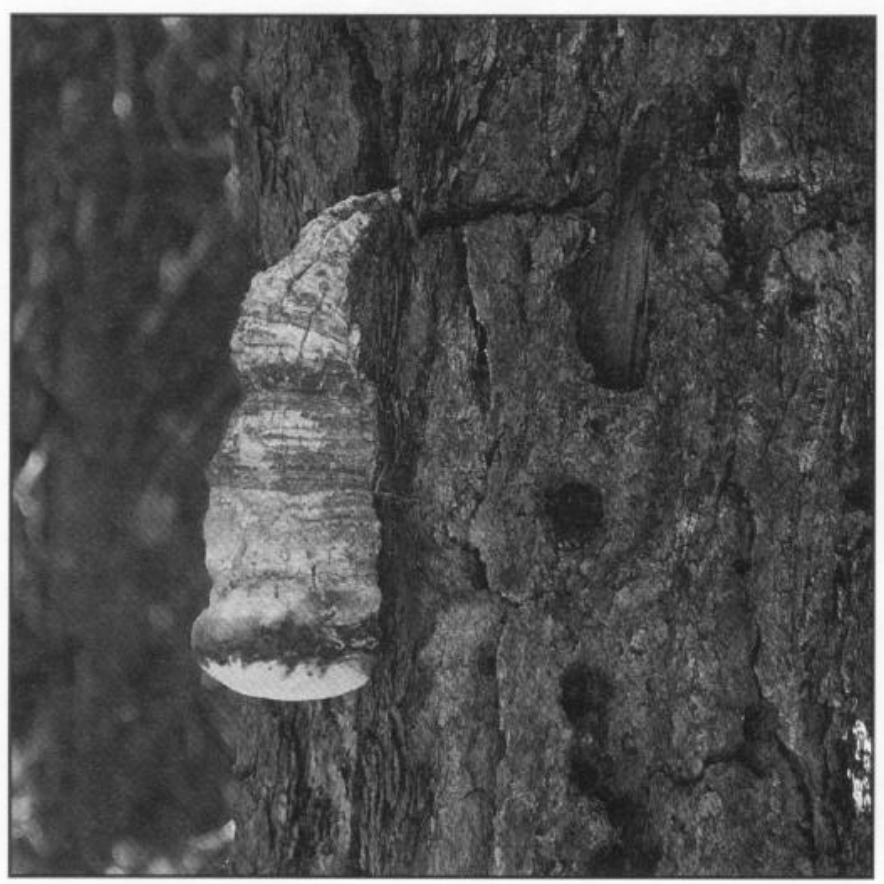

Figure 11 - Fruiting bodies of brown trunk rot are hoof-shaped or cylindric with a chalky consisiency. The upper surface is yellow, white, or cream, and the under surface is yellow or white with a pored texture. The fungus causes a brown cubical decay. White felts may be found in shrinkage cracks of decayed wood.

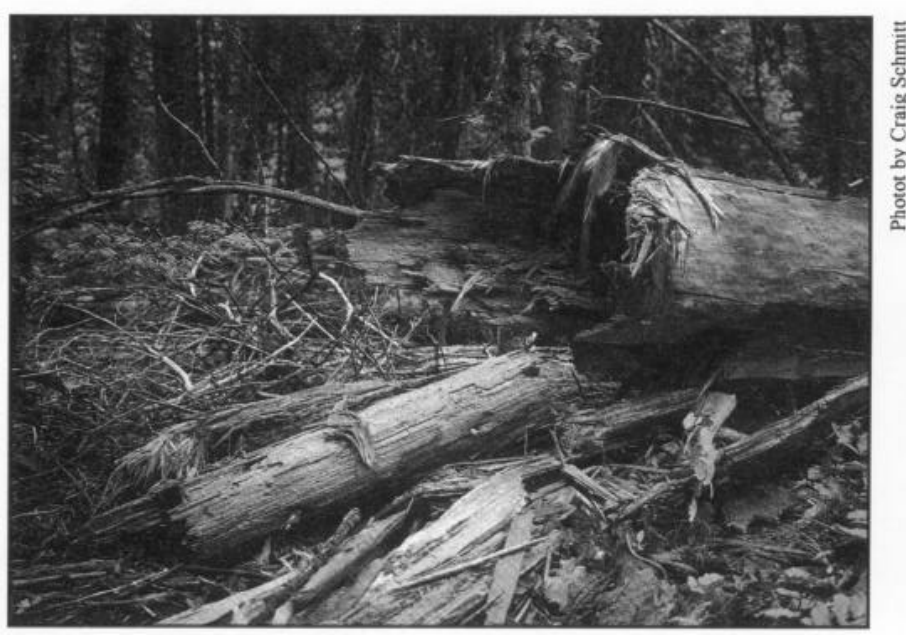

Figure 10-The decay caused by Indian paint fungus is restricted to the heartwood of the tree, and older trees often become hollow. Advanced decay is stringy and reddish brown to yellow.

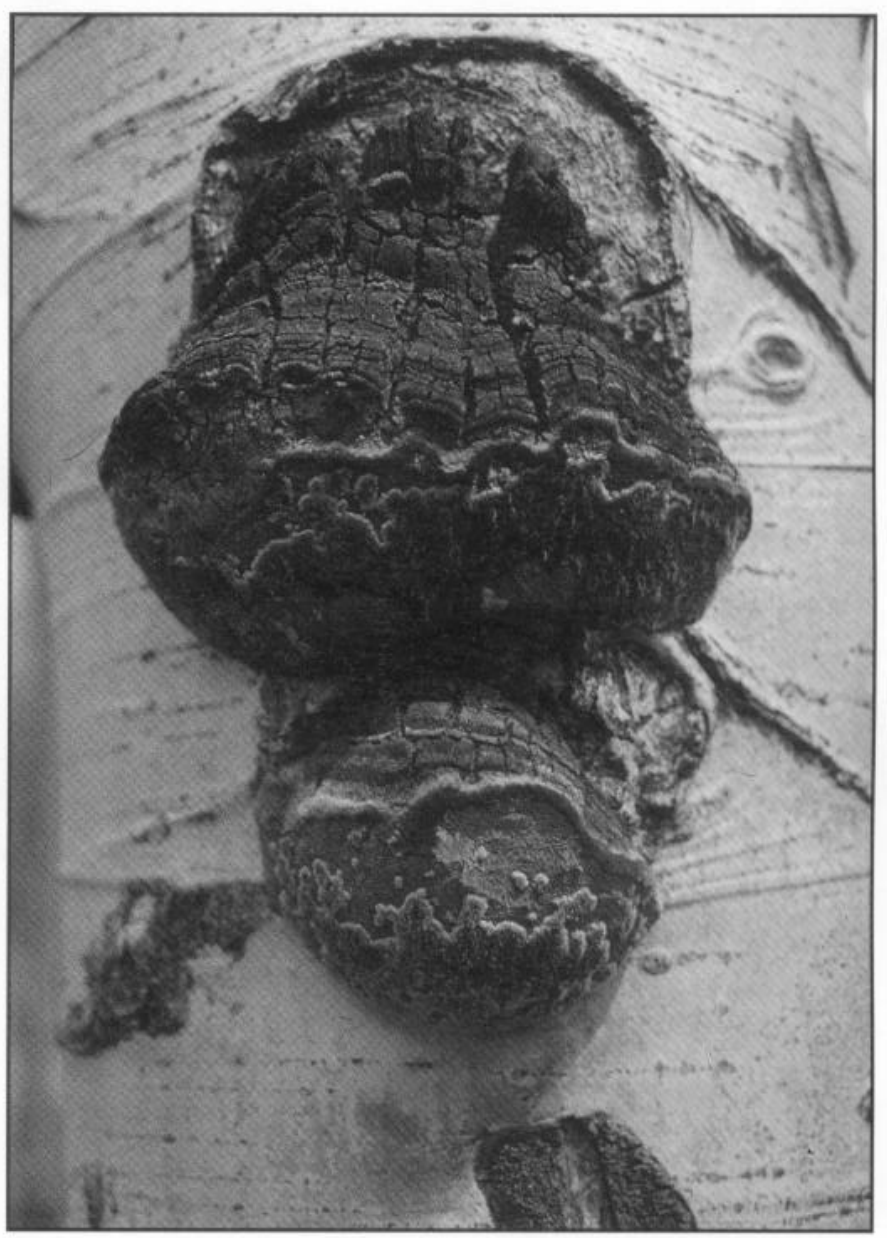

Figure 12-Fruiting body of Phellinus tremulae on quaking aspen. 


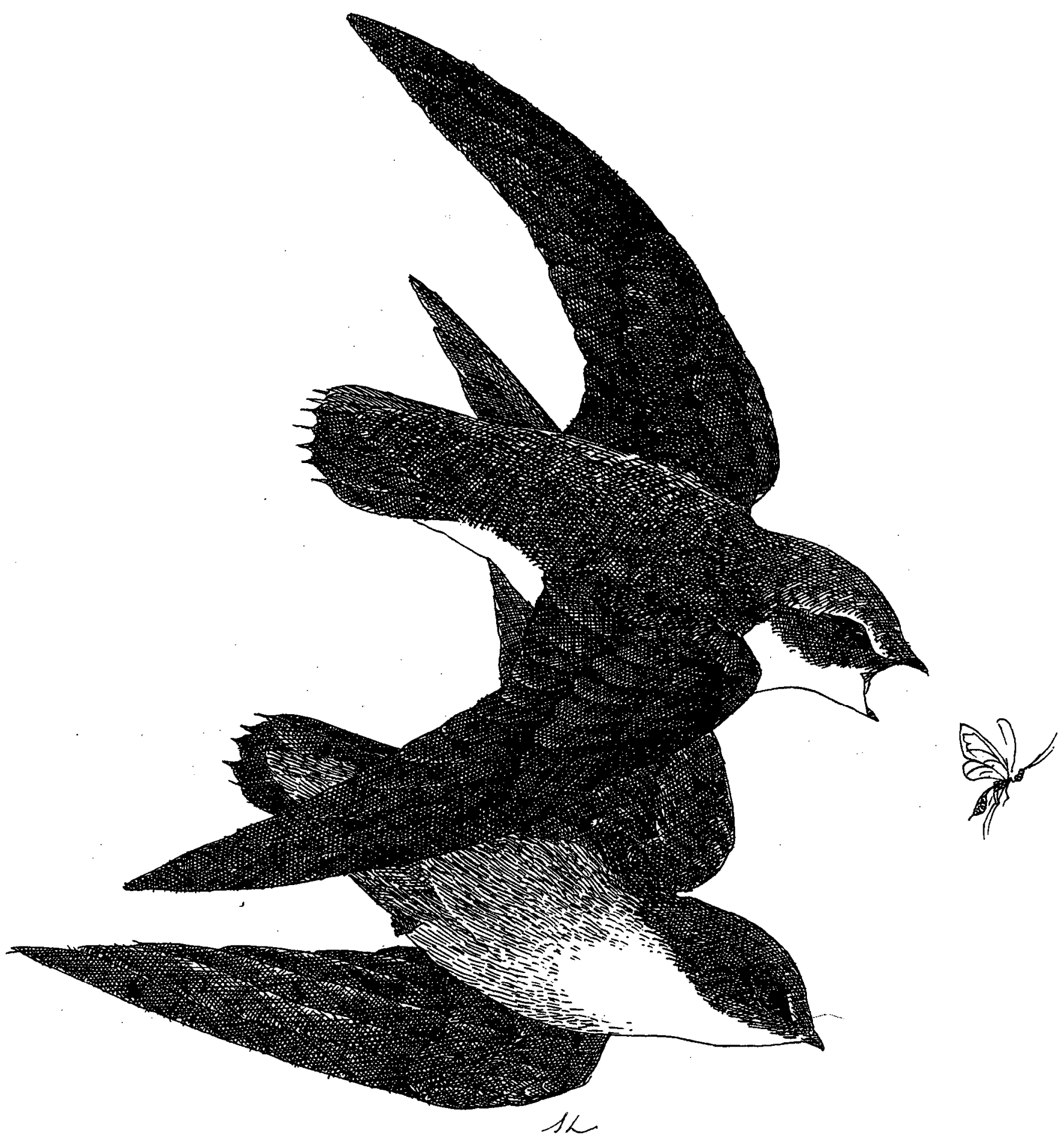




\section{HOLLOW TREES}

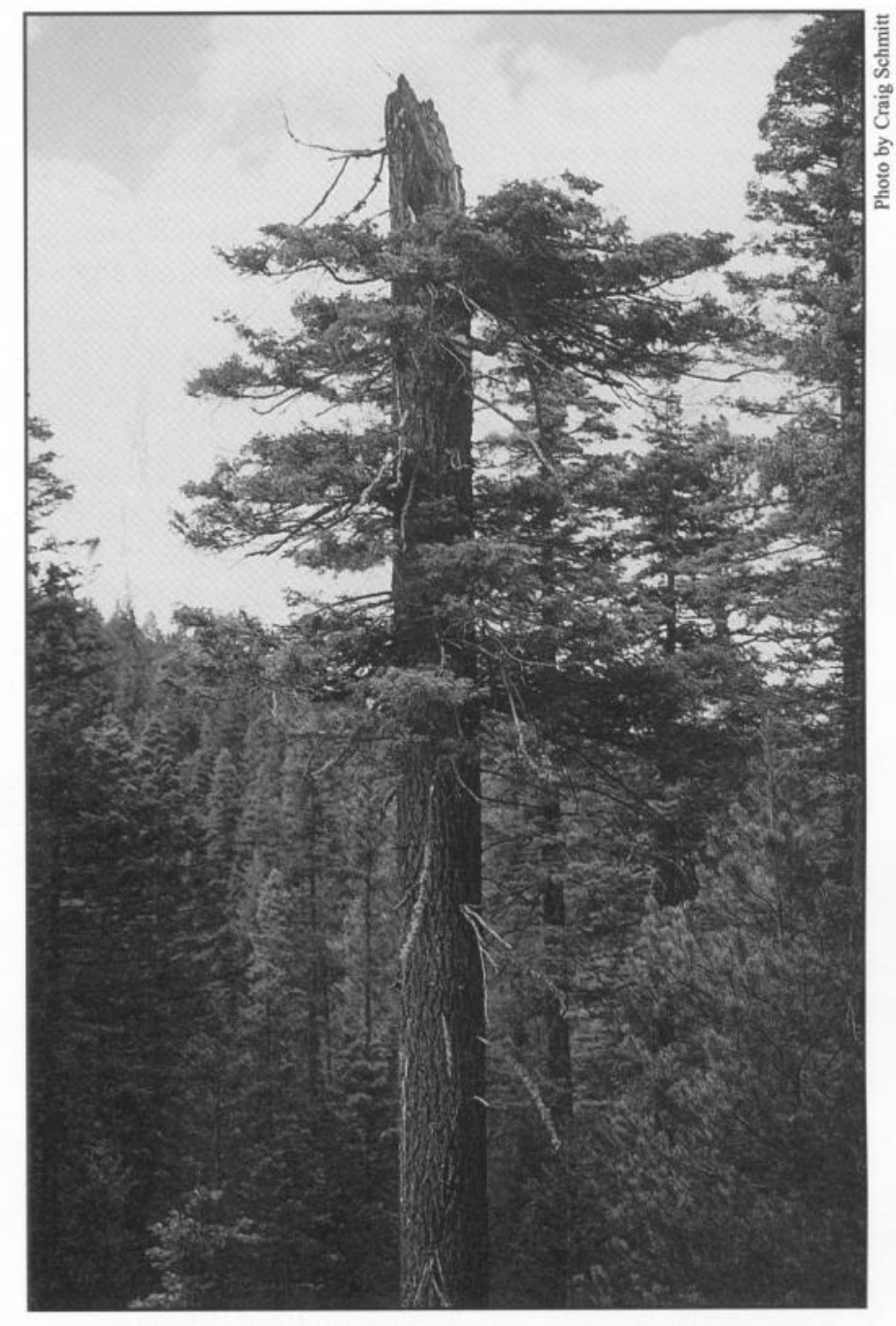

\section{Ecological Processes and Functions}

We define a hollow tree as a tree having decay in the heartwood so advanced that it leaves a hollow core. Largediameter trees, those more than 20 inches in diameter at breast height (d.b.h.), form hollow chambers most useful to wildlife.

The importance of hollow trees to wildlife has only recently been recognized. Hollow trees with broken tops are used by black bears (Ursus americanus) for den sites (Akenson and Henjum 1994, Hamilton and Marchinton 1980, Noble and others 1990, Parks 1996a). These arboreal dens provide females and subadults with sites that are safe from predaceous, large, male bears. Hollow chambers at the bases of some trees also are used as den sites (fig. 13).

Pileated woodpeckers use hollow trees for roosting at night (Bull and others 1992); they excavate their own entrance holes to the hollow chambers and do not depend on broken tops for access. Entrance holes excavated by the woodpeckers allow other species to enter, such as flying squirrels (Glaucomys sabrinus), bushy-tailed woodrats (Neotoma cinerea) (fig. 14), bats (Nagorsen and Brigham
1993), American martens (Martes americana), northern flickers (Colaptes auratus), and Vaux's swifts (Chaetura vauxi).

Martens frequently use hollow trees for denning, as well as for resting and hunting (Bull 1995) (fig. 15). Use of such trees provides dry rest sites during inclement weather. Vaux's swifts must have hollow trees for both nesting and roosting in forests (Bull and Collins 1993) (fig. 16). Swifts readily enter these trees, either through an open top or through an entrance hole excavated by a pileated woodpecker.

\section{Decay Process}

A hollow tree is created when heart-rot fungi invade the heartwood of a living tree, and decay progresses to the point that the cylinder of decayed heartwood eventually detaches from the sapwood and slumps downward, leaving a hollow chamber. This process begins only in a living tree and can take many decades to produce a chamber large enough for wildlife to use. Because this particular decay process is dependent on living trees, the only way to obtain a hollow dead tree or log is to start with a living tree hollowed out by decay. 
Heart-rot fungi do not typically kill trees, but trees with advanced heart rot often have broken tops because the hollow interior weakens the bole. Because the trees are living, a bayonet top may form where new leaders grow around and over the broken top forming an umbrella of foliage (figs. 17 and 18). Hollow trees provide valuable wildlife habitat for decades before they eventually die and become hollow snags (fig. 19) or fall over as hollow logs (fig. 20).

\section{Selecting Hollow Trees}

No artificial means to create or encourage the formation of a hollow tree structure has been found, so retaining such trees in managed stands is essential to providing habitat for the species that depend on them. Large-diameter trees that show some evidence of being hollow are of the greatest value. In the absence of apparently hollow trees, large trees of the species most commonly producing this structural feature, such as grand fir and western larch, should be conserved.

A large-diameter tree is vital because the chamber typically consists only of the former heartwood. To be most useful, the chamber must be large enough for a swift to fly up and down, for a pileated woodpecker to enter; or for a bear to occupy. All of these wildlife species typically use entrances from 30 to 80 feet off the ground, where the heartwood cylinder needs to be large enough to provide a chamber of suitable size. The average size of 21 trees used by swifts for nesting was 27 inches d.b.h. and 85 feet in height in northeastern Oregon (Bull and Collins 1993). Bear dens'in hollow trees with top entries averaged over 43 inches d.b.h. and 57 feet tall in northeastern Oregon (Akenson and Henjum 1994). Pileated woodpeckers roosted in hollow trees that averaged 28 inches d.b.h. and 74 feet tall in northeastern Oregon (Bull and others 1992).

Evidence that large-diameter trees have hollow interiors includes the following:

- A broken bole with a bayonet top formed over the break (figs. 17 and 18)

- More than one pileated woodpecker entrance hole

- Fruiting bodies of Indian paint fungus (fig. 8)

- An old injury or bend along the bole where a new leader formed a new trunk many years ago.

In northeastern Oregon, grand fir and western larch make up most of the hollow trees used by wildlife. All 56 nest and roost trees used by swifts were grand fir (Bull 1996a). Sixtyone percent of 123 pileated woodpecker roost trees (Bull and others 1992), and 8 of 10 arboreal bear dens were in grand fir as well (Akenson and Henjum 1994). The remainder of hollow trees used by pileated woodpeckers or black bears were primarily western larch and a few ponderosa pine. We suspect hollow chambers may be common in old western redcedar (Tsuga plicata) in the interior Columbia River basin, because hollows caused by heart rot in old western redcedar trees are used by pileated woodpeckers for roosting in western Washington (Parks and others 1997) and in the
Oregon Coast Range (Mellen 1987).

Although lodgepole pine, Douglas-fir, subalpine fir, Engelmann spruce (Picea engelmannii), and western white pine are subject to heart rot, they seldom form a hollow chamber. These species should not be retained with the expectation that they might produce hollow trees.

Information on the number of hollow trees to retain for wildlife use is limited. Bull and others (1992) suggest leaving 44 grand fir roost trees ( 0.07 per acre) known to be hollow or 880 grand fir trees ( 1.47 per acre) suspected of being hollow in each 600 -acre pileated woodpecker management area to provide trees for roosting. No models have been developed to predict the portion of hollow stem, based on the presence of conks alone, in large-diameter, living grand fir.

Large, hollow trees are uncommon in managed landscapes and typically are found only in late- and old-seral stands of grand fir and western redcedar. Although isolated hollow trees in young stands have significant value to wildlife, these young stands cannot reproduce this type of structure for at least 150 to 200 years. The late-seral, multilayer stands that produce hollow trees comprise less than 3 percent of the forested landscape in the interior Columbia River basin (Hann and others, in press). Retaining all hollow trees in managed landscapes can be justified in most areas because so little of the landscape has them, they have little commercial value, and they are of great value to wildlife. Rarely, where large blocks (in excess of 600 acres) of this habitat have many hollow trees (in excess of 10 per acre), does the number of hollow trees probably exceed the wildlife need for habitat.

\section{Review}

- A hollow tree is created by heart-rot fungi. This kind of decay initiates only in a living tree.

- Evidence that a tree has a hollow interior includes a broken bole with a bayonet top, more than one pileated woodpecker cavity, fruiting bodies of Indian paint fungus, or an old injury or bend along the bole where a new leader formed a new trunk many years ago.

- Hollow trees are known to be used by pileated woodpeckers, northern flickers, Vaux's swifts, American martens, flying squirrels, black bears, bats, bushy-tailed woodrats, and other small mammals as dens, roosts, nests, forage sites, and shelter.

- Large-diameter hollow trees provide the best wildlife habitat; the mean d.b.h. of hollow trees used by black bears was 43 inches; by pileated woodpeckers, 28 inches; and by Vaux's swifts, 27 inches.

- Tree species that most commonly form hollow interiors are grand fir, western larch, and western redcedar.

- Retaining all hollow trees in managed landscapes can be justified in most areas because these trees are uncommon, occur on less than 3 percent of the landscape, have little commercial value, and have great wildlife value. 


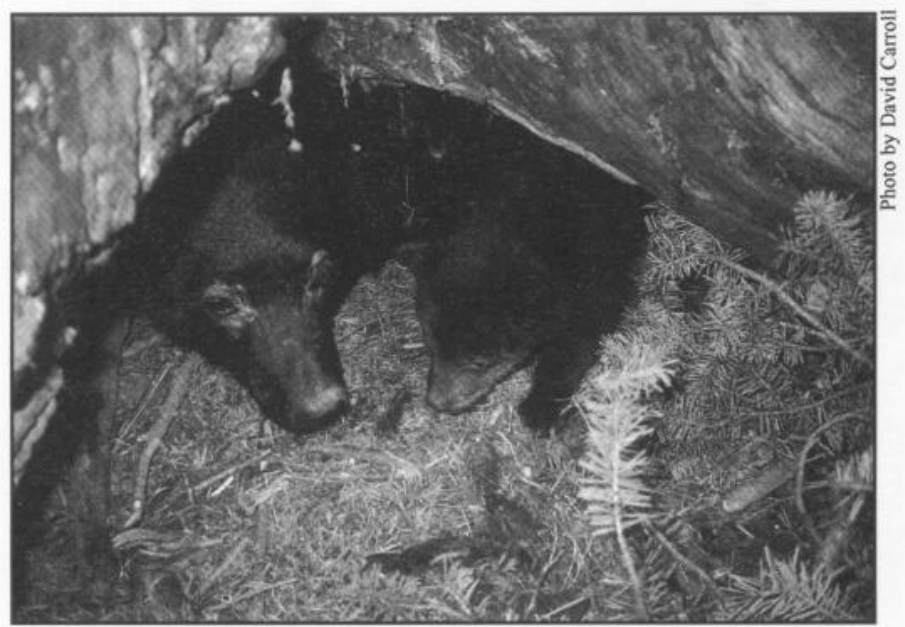

Figure 13-Black bear sow and cub in a winter den in the base of a living grand fir.

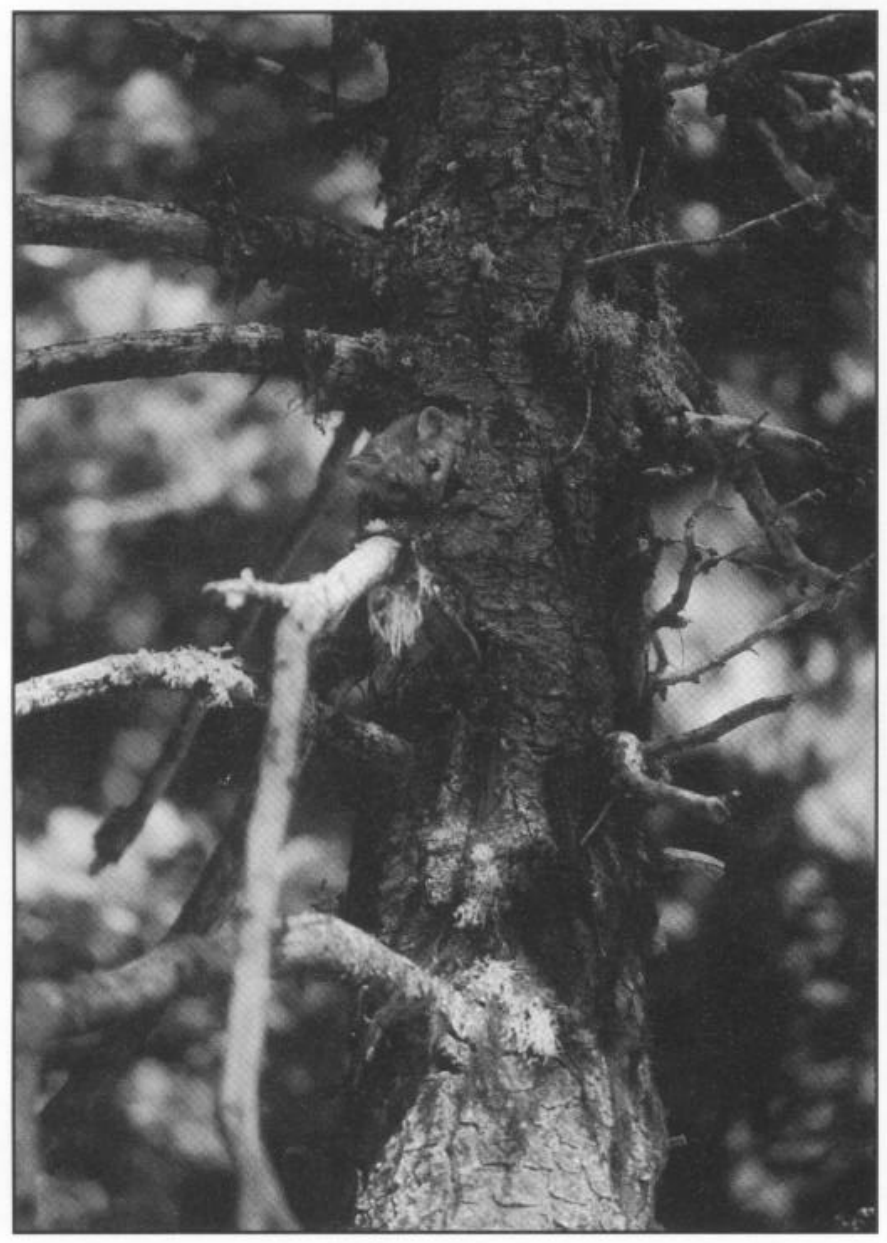

Figure 15-American martens use hollow trees for denning and shelter.

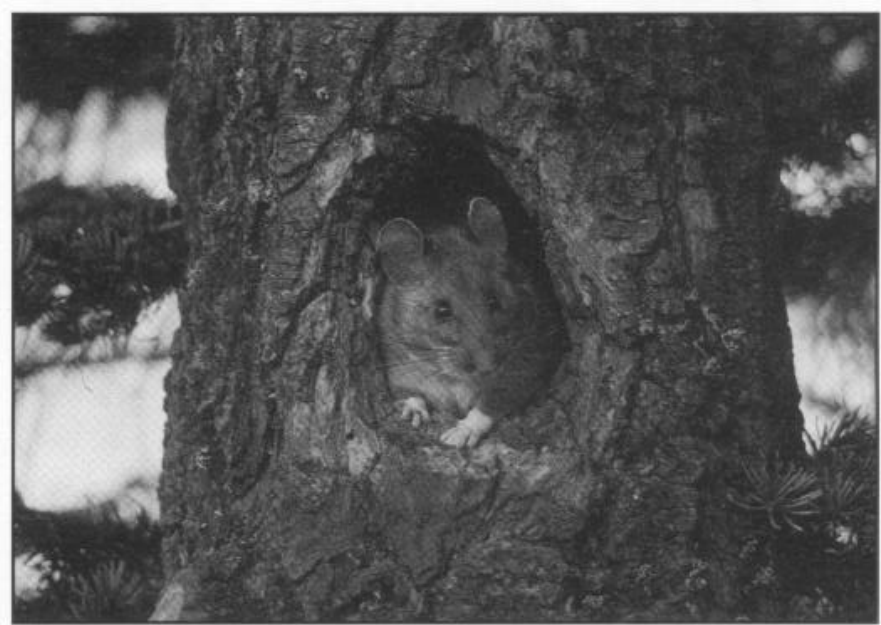

Figure $14-$ Entrance holes are excavated by pileated woodpeckers into hollow trees, allowing access by bushy-tailed woodrats and other wildlife.

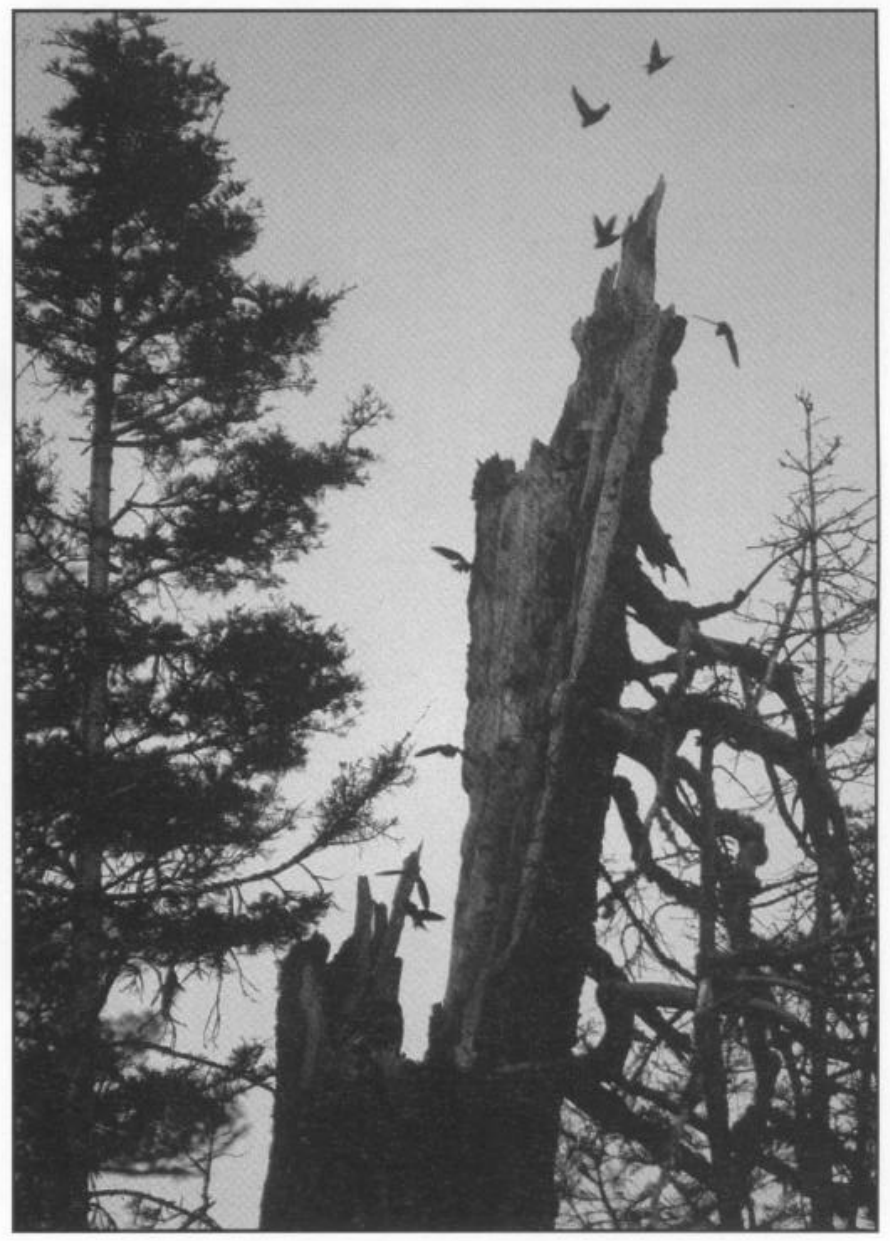

Figure 16-Vaux's swifts both nest and roost in hollow trees. 


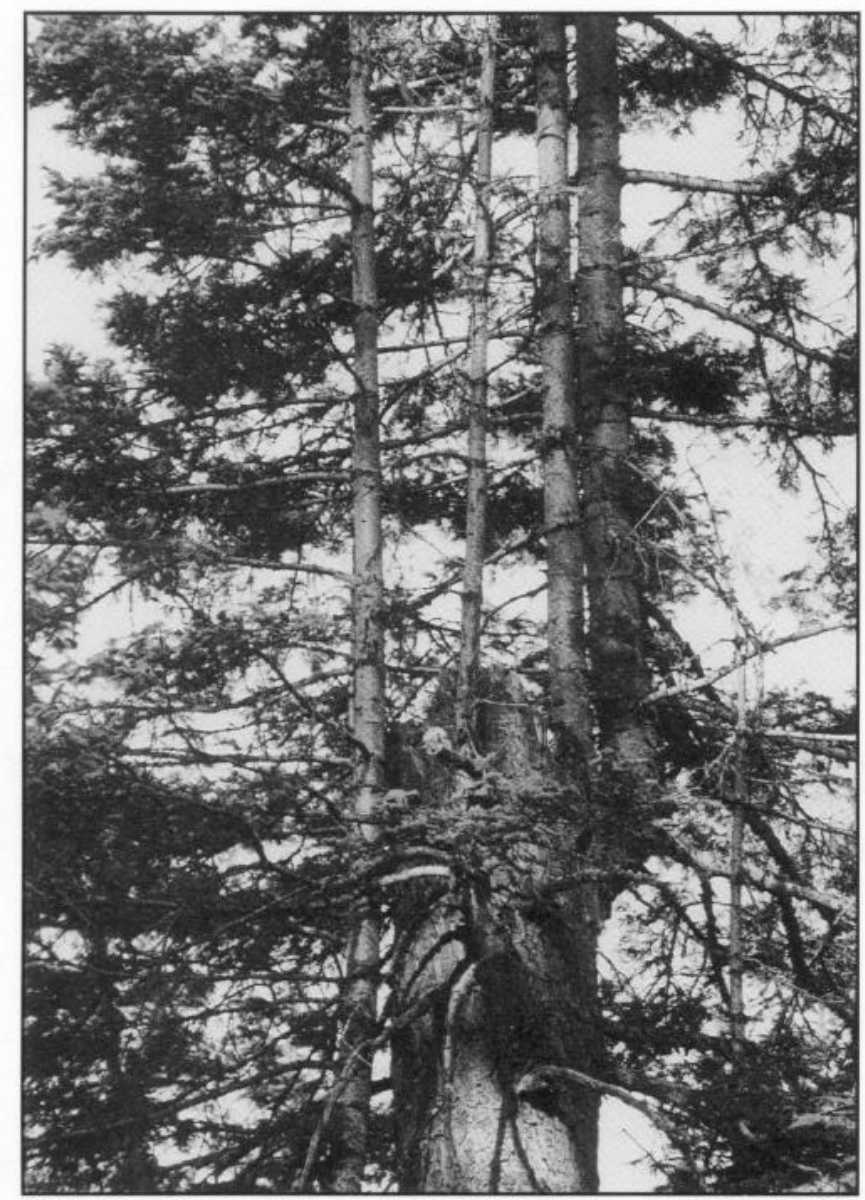

Figure 17-Broken tops are common in hollow living trees. One or more bayonet tops often form over the break.

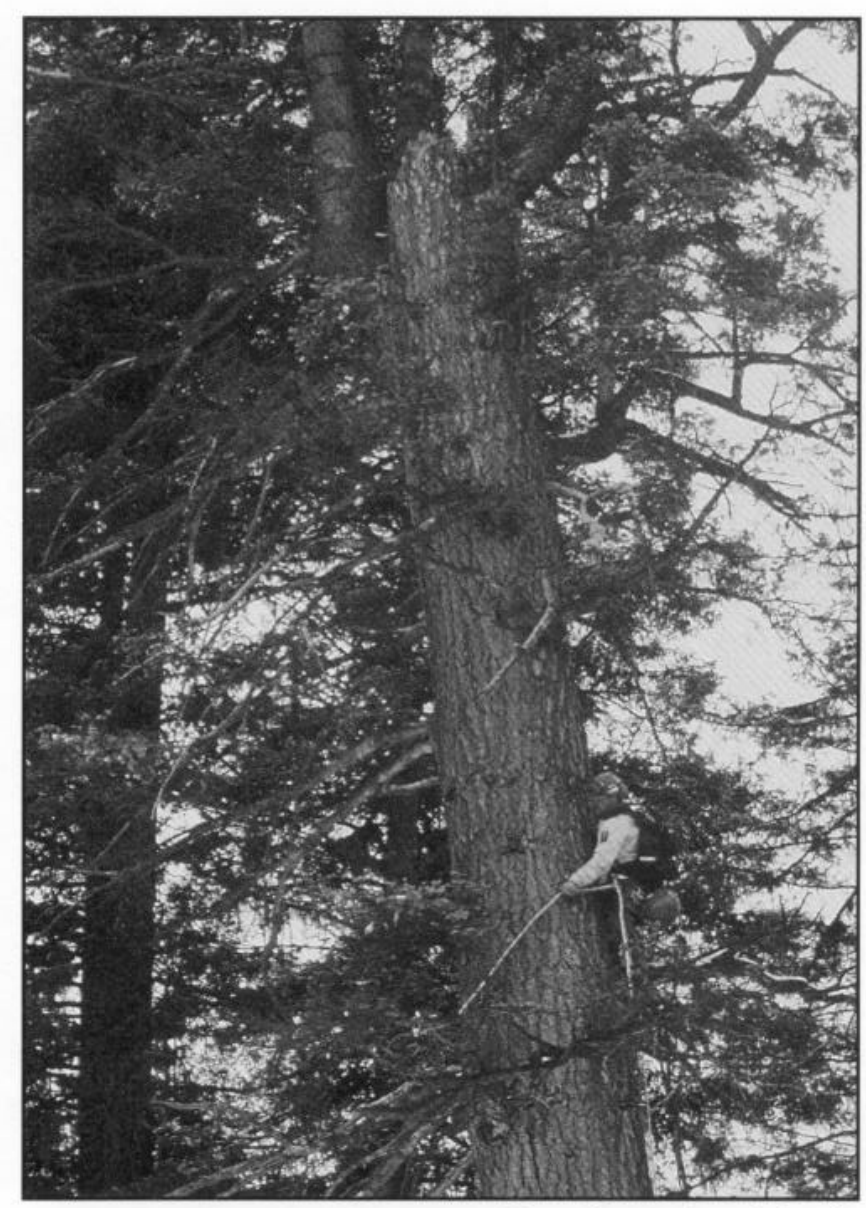

Figure 18-A 350-year-old hollow grand fir used as an arboreal den site by black bears. The bayonet top is more than 80 years old.

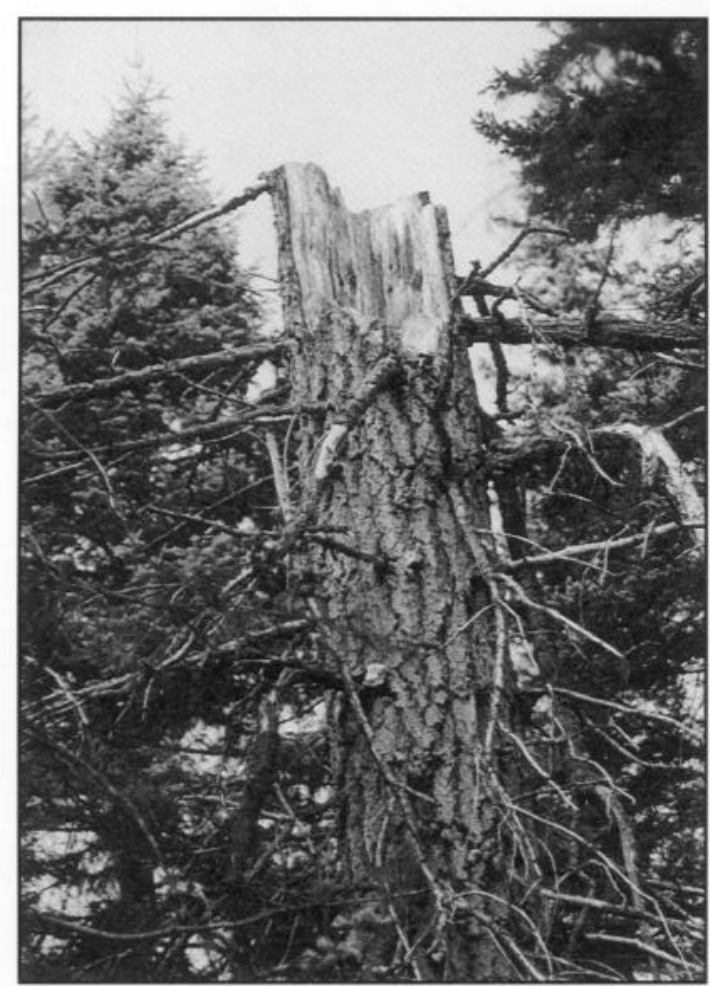

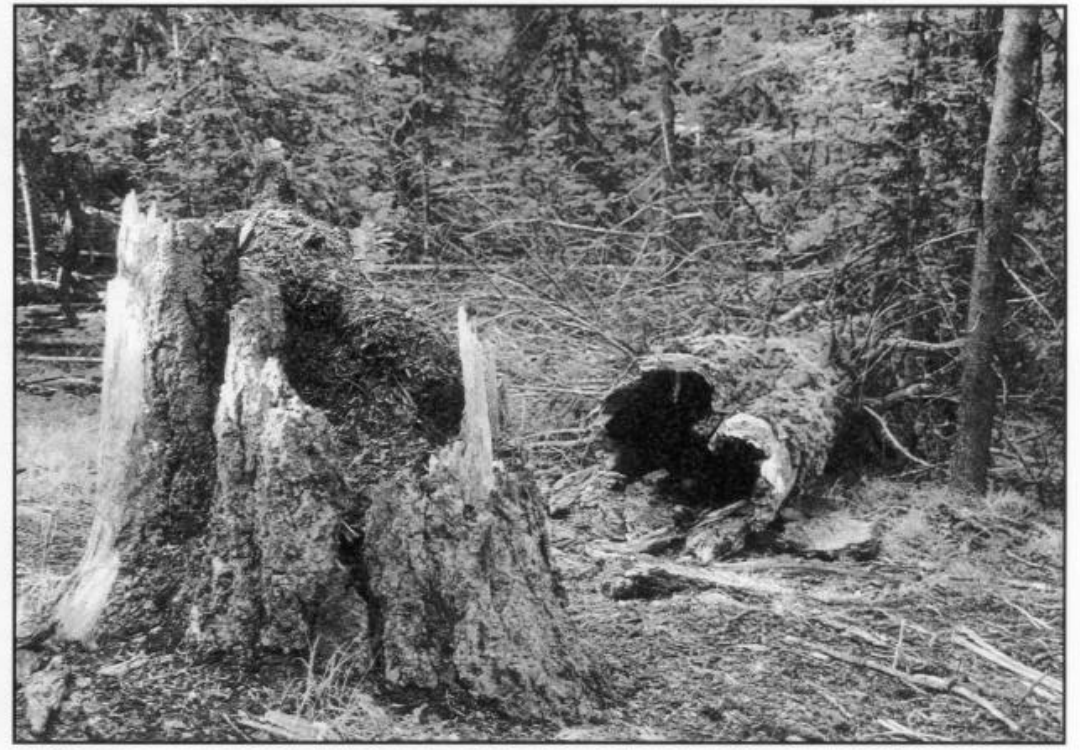

Figure $20-$ Hollow logs originate only from living trees that were colonized by heart-rot fungi.

Figure 19 Hollow dead trees originate only from living trees in which the heartwood chamber has been decayed by heart-rot fungi. 


\section{BROOMED TREES}

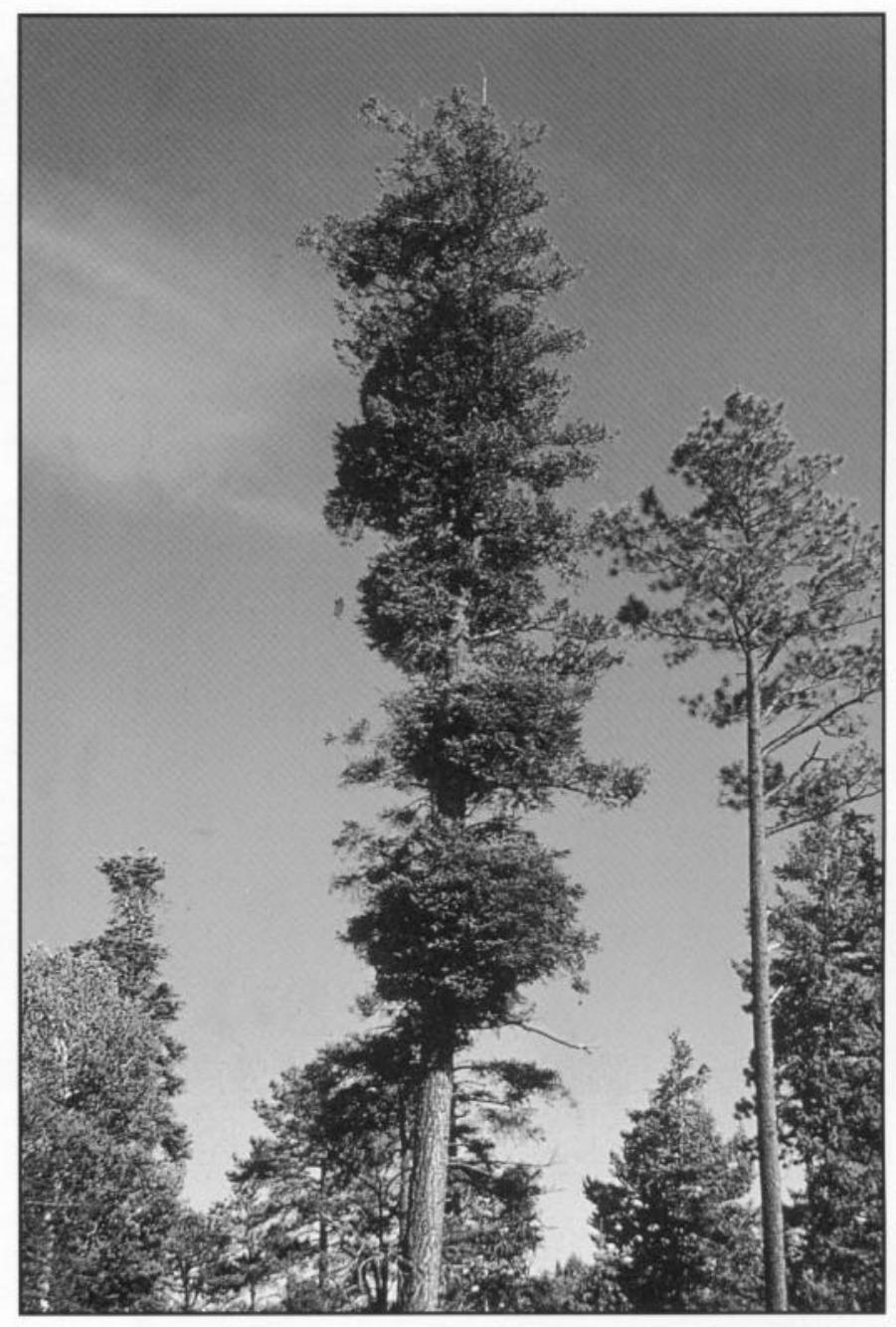

The dense misshapen branches of witches' brooms sometimes found in conifers, provide unique wildlife habitat in interior Columbia River basin forests. Brooming is most often caused by the dwarf mistletoes (Arceuthobium spp.), rust fungi (Chrysomyxa spp. or Melampsorella spp.), or a needle cast fungus (Elytroderma deformans). These three groups of organisms will be discussed separately.

\section{Dwarf Mistletoes}

Ecological processes and functions - Dwarf mistletoes are perennial parasitic plants that derive water and nutrition from their hosts (figs. 21-26). Most dwarf mistletoes are host-specific, but trees of all ages can be infected. Dwarf mistletoes typically produce spindle-shaped branch swellings at the point of infection. A few years after infection, dwarf mistletoes produce distinctive shoots on swollen branches that become witches' brooms after several years. Over many years, infection will increase on individual trees and within stands. Heavily infected trees grow more slowly in diameter and height than do lightly infected or uninfected trees. Heavily infected trees produce fewer cones and seeds and often develop spike tops. Eventually, heavily infected trees die. The most commonly affected tree species in interior Columbia River basin forests are Douglas-fir, lodgepole pine, ponderosa pine, and western larch (Hawksworth and Wiens 1996).

Trees infected with dwarf mistletoes can be directly or indirectly beneficial to wildlife. Wildlife species consume mistletoe shoots and fruits, forage for insects in mistletoe plants and brooms, and use witches' brooms for cover and as nesting sites (Hawksworth and Wiens 1996, Mathiasen 1996). Dwarf mistletoes cause openings and changes in stand structure by killing trees (Nicholls and others 1984).

The shape, size, and position in the tree of dwarf mistletoe brooms differ considerably and influence their potential wildlife use. The characteristic shape and size of brooms depend on where and how they form along the bole. Three types of brooms are recognized (Tinnin and Knutson 1982, 1985).

Brooms that form platforms are best suited to raptors for nesting. Brooms are habitual nest sites for northern spotted owls (Strix occidentalis) (Forsman and others 1984, Martin and others 1992), long-eared owls (Asio otus) (Bull and others 1989), goshawks (Accipiter gentilis), and Cooper's 


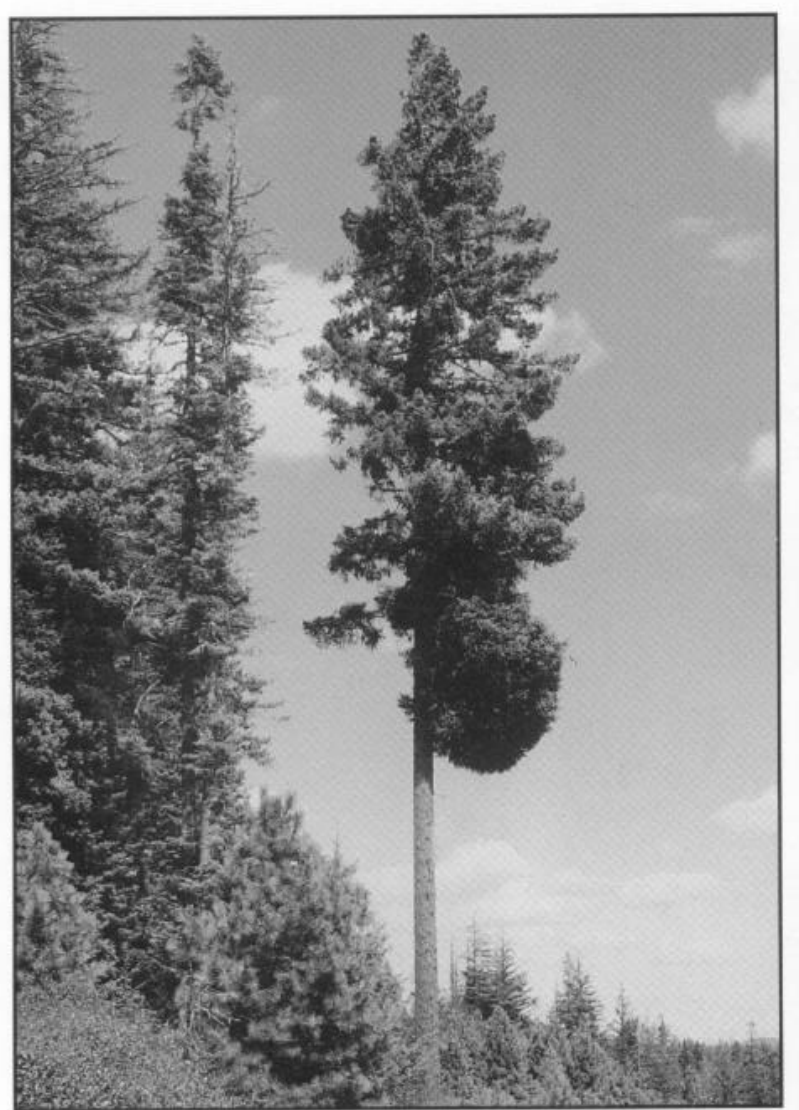

Figure 21-Douglas-fir dwarf mistletoe may form large, drooping brooms. Brooms are generally more abundant in the lower crown.

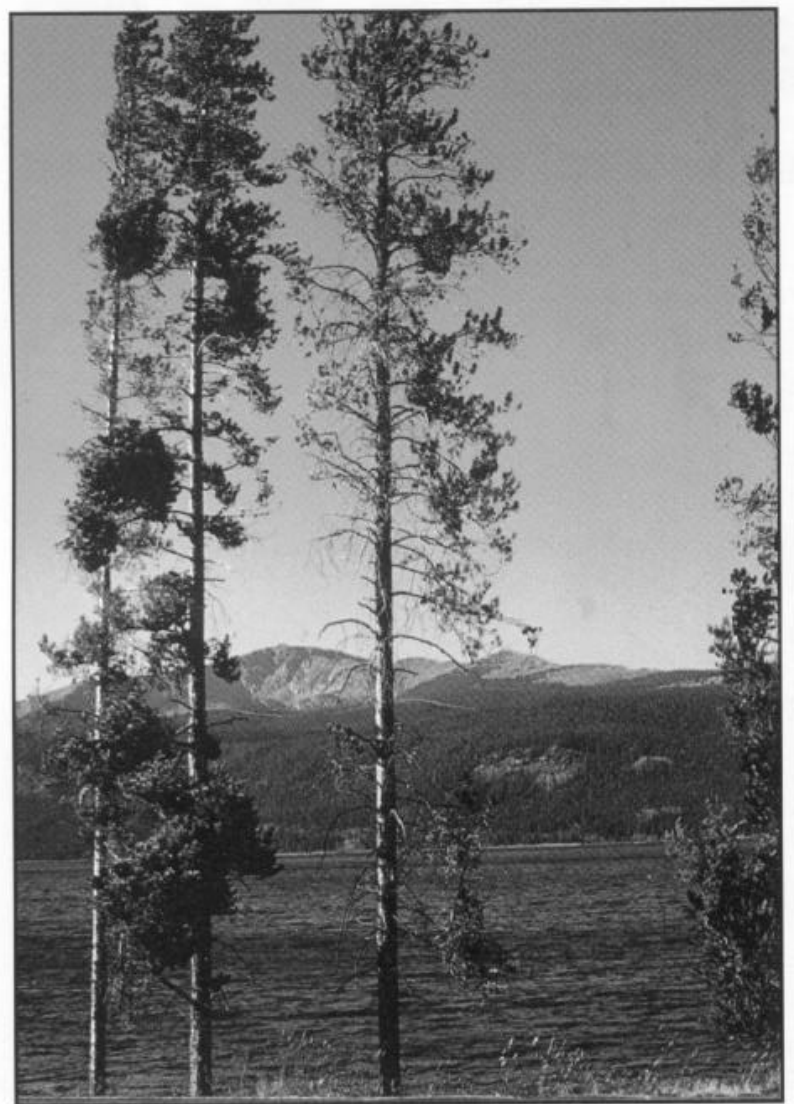

Figure 23-Dwarf mistletoe brooms on lodgepole pine.

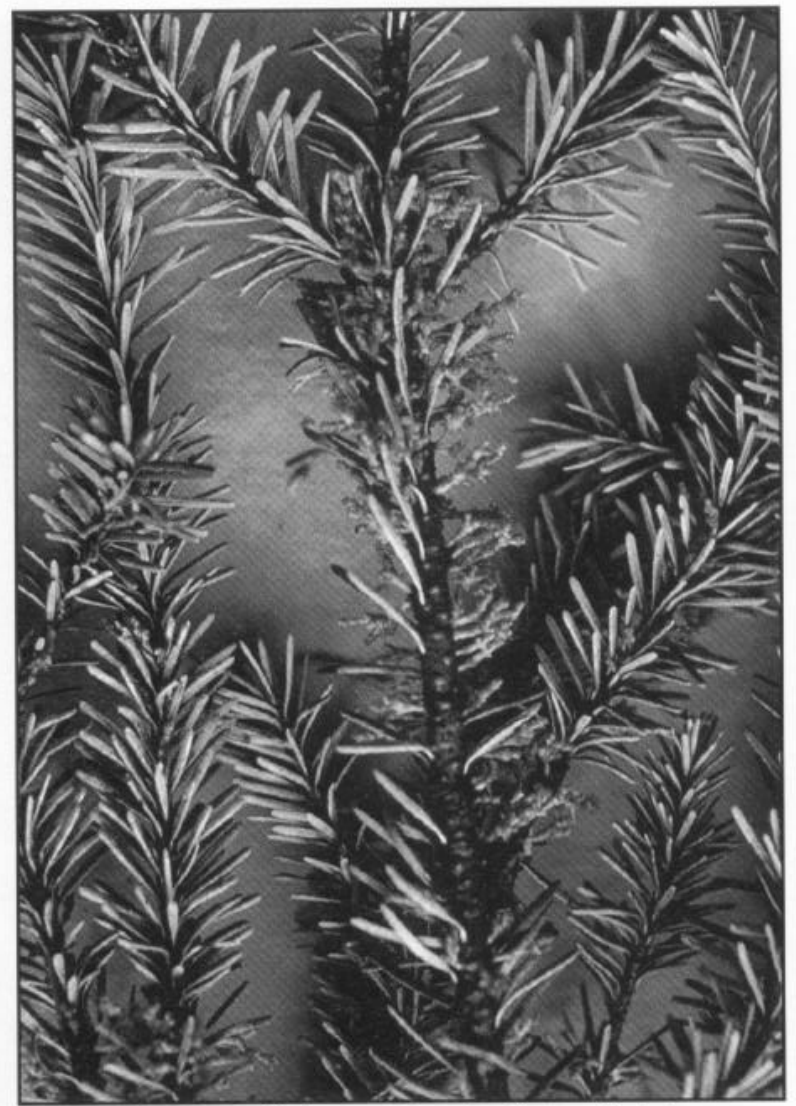

Figure 22-The aerial shoots of Douglas-fir dwarf mistletoe are smaller than the host needles ( 0.5 to 0.75 inches) and may not always be present on broom branches.

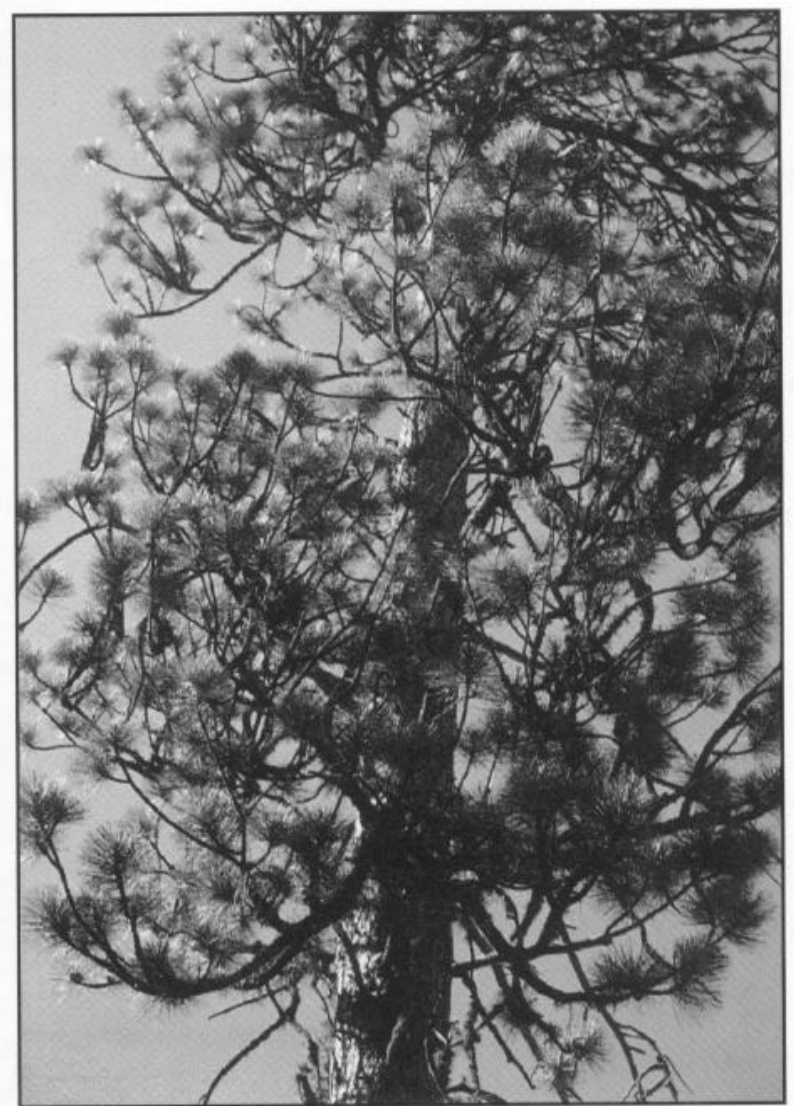

Figure $24-$ Open brooms and distorted branching caused by dwarf mistletoe on ponderosa pine. 


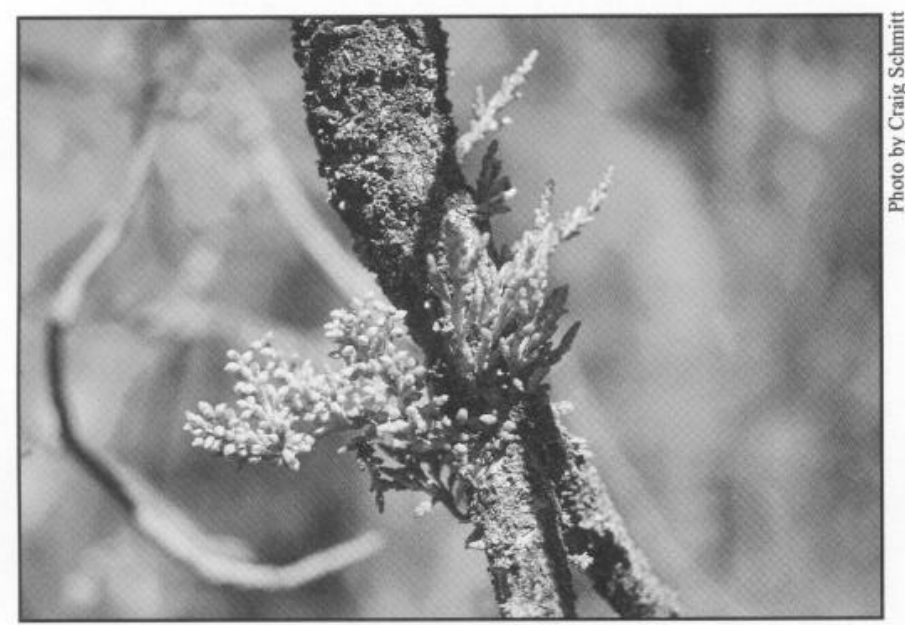

Figure 25-Aerial shoots of dwarf mistletoe often are present on infected ponderosa pine.

hawks (Accipiter cooperii) (Reynolds and others 1982). Some song birds also nest in witches' brooms (Hawksworth and Wiens 1996).

Long-eared owls nest on platforms of Douglas-fir dwarf mistletoe (Arceuthobium douglasii) brooms that average 14 by 19 inches in diameter, with an average depth of 9 inches (Bull and others 1989). Douglas-fir brooms used by great horned (Bubo virginianus) and great gray owls (Strix nebulosa) exceed 3 feet in diameter (Bull 1996b). Brooms selected by northern spotted owls are usually the larger and denser brooms located away from the stand edge (Martin and others 1992). The specific structural characteristics of brooms associated with nests of other wildlife species have not been documented and warrant further investigation.

Witches' brooms caused by Douglas-fir dwarf mistletoe commonly are used by blue grouse (Dendragapus obscurus) for roosting cover (Martinka 1972, Stauffer and Peterson 1986), and they eat mistletoe seeds (Seversen 1986).

The shoots of ponderosa pine dwarf mistletoe $(A$. campylopodum) are an important fall and winter food for porcupines (Erethizon dorsatum) (Hooven 1971, Lawrence 1957). Chipmunks (Tamias spp.) commonly eat mistletoe seeds (Broadbooks 1958, Nicholls and others 1984). Squirrels and porcupines feed selectively on mistletoe-infected twigs in preference to uninfected twigs (Johnson and Carey 1979, Wood and others 1985) and use the brooms as winter resting cover (Smith 1982). American martens use brooms in lodgepole pine (Burnett 1981, Buskirk and others 1987,

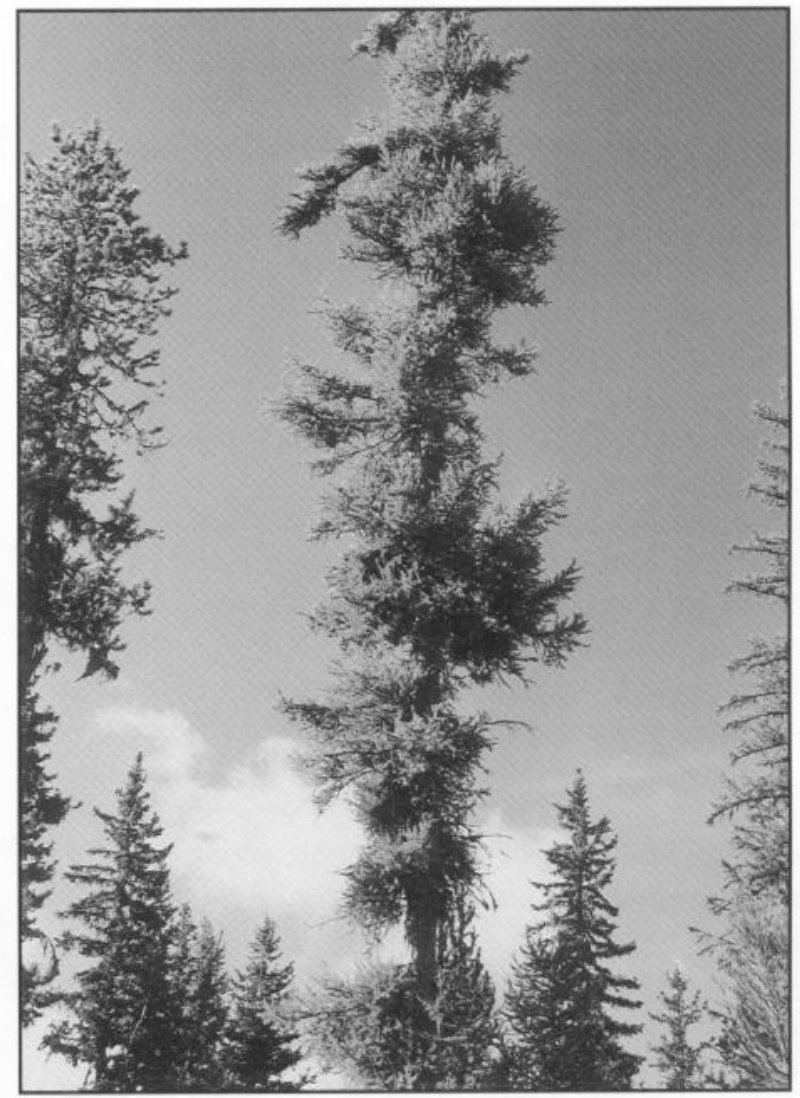

Figure 26-Western larch with dwarf mistletoe brooms provide good nesting platforms that raptors use.

Campbell 1979, Spencer 1987), Douglas-fir, and western larch (Bull 1995) for resting sites.

Although these plants have a high nutritive value (Urness 1969), they are usually too high in the trees to be accessible to deer and elk, which eat shoots that fall to the ground, however. Mistletoe shoots are a regular component in mule deer diets (Leach and Hiele 1957, Wright and Arrington 1950 ) and can provide a high-protein winter food for elk (Craighead and others 1973). Clary and Larson (1971) found that in certain years, ponderosa pine stands with dwarf mistletoe sheltered significantly more deer than stands without dwarf mistletoe.

Dwarf mistletoes are a natural part of the Northwest forest ecosystems; they have coevolved with their hosts for millions of years (Hawksworth and Wiens 1996). Dwarf mistletoes should be valued and recognized as a functional and beneficial wildlife resource. Bennetts and others (1996) found a direct positive correlation among the intensity of dwarf mistletoe and the diversity and total number of birds in ponderosa pine stands. They also demonstrated a positive correlation between numbers of snags and intensity of dwarf mistletoe infection. Nearly three times as many cavitynesting birds were found in heavily infested stands as in comparable uninfested stands.

Infection process-Dwarf mistletoes spread from tree to tree by way of an explosive fruit mechanism. Fruits produced on female plants contain one seed that is forcibly expelled during late summer or fall. Seeds are coated with a 
sticky substance that allows them to adhere to objects they strike. Seeds that land on susceptible trees can cause new infections. Seeds usually land within 20 feet from their origin, as a consequence, the spread of dwarf mistletoes is relatively slow (only 1 to 2 feet per year). Spread from tree to tree and spread in individual trees is more rapid in forests with multistoried structures (Parmeter 1978).

Birds and mammals can pick up the sticky seeds on their bodies and transport them to new infection sites

(Hawksworth and others 1987, Lemons 1978). Spreading by birds is considered important in introducing initial infection into uninfected stands.

Because dwarf mistletoes only grow and reproduce on living trees, any ecological process or management option that kills the host will eliminate dwarf mistletoes. Wildfire is believed to have historically kept populations of dwarf mistletoe in check (Alexander and Hawksworth 1975). The dwarf mistletoe population is reduced immediately after a burn, but as a new stand develops, dwarf mistletoe populations increase from seeds cast down from surviving trees. These overstory trees infect the developing young trees, or mistletoe is reintroduced into the new stand from adjoining infested stands.

Management implications-Managing stands to retain mistletoe-infected trees has both benefits and drawbacks. Careful selection of infected trees will benefit wildlife; however, heavy mistletoe infection of a stand may adversely affect some wildlife. Trees that are heavily infected produce fewer, smaller cones of poorer quality (Hawksworth and Shaw 1984). This reduction in cones can affect both tree regeneration and cone-feeding wildlife. Although small patches of dead trees provide diversity, extensive tree mortality may cause loss of canopy cover that protects wildlife from extreme weather and predation.

Martinka (1972) found heavy use by blue grouse in the most severely infested Douglas-fir stands. He suggests curtailing the thinning of overstocked stands and destroying infected Douglas-fir in areas important for blue grouse breeding. These thickets are often in areas where the trees are ill-adapted to the site. To assure that adequate wildlife habitat is maintained in managed forests, mistletoe-infected portions of stands identified as being important for blue grouse breeding and resting should be retained.

Reynolds and others (1992) suggest that although brooms are beneficial as nesting habitat for goshawks, changes in stand structure caused by dwarf mistletoes can be detrimental to some goshawk prey species. For example, ponderosa pine stands heavily infested with southwestern dwarf mistletoe ( $A$. vaginatum subsp. cryptopodum) become stagnated and may not develop beyond the young-forest stage or may revert, because of high mortality, to the grass-forb-shrub stage. Management recommendations for developing the desired forest conditions could include thinnings, with removal of trees with brooms high in the crown to reduce the detrimental effects of mistletoe in the goshawk postfledgling family and foraging areas. Selecting reserve trees free of, or only lightly infected with, dwarf mistletoe may be desirable.

High dwarf mistletoe populations may put the stand at risk to stand-replacing wildfire. Dwarf mistletoes were restricted by fire in pre-European forests; frequent fires were the rule in the drier communities, where dwarf mistletoe is most prevalent (Hessburg and others 1994). Fire tended to reduce infection of mistletoe in stands by removing a higher proportion of trees with heavy infection (Alexander and Hawksworth 1975). Low-hanging brooms and broken brooms around the bases of infected trees allowed higher burning temperatures and greater flame lengths (Wicker and Leaphart 1974), thereby making the stand more susceptible to crown fire. Stands recently invaded by Douglas-fir after fire exclusion may have a steadily increasing risk of crown fires where infection centers develop.

Although dwarf mistletoes are a native component of the interior Columbia River basin forests, the effects that these parasites have on tree growth and survival is an important forest management issue, not only for timber production, but also for wildlife and other resources. Because they are obligate parasites, dwarf mistletoes can be effectively reduced to meet management objectives by using silvicultural treatments that emphasize the removal of infected trees.

Selecting trees-When selecting infected tree species for wildlife use, we believe that choosing groups of lightly infected trees, where the brooms appear large and dense enough to furnish a nesting platform, will provide the most benefits to wildlife. Infected trees left in groups rather than as individual trees throughout the stand can be effectively isolated from the rest of the stand by maintaining a buffer of nonhosts or an unstacked area. The buffer or unstacked area needed to limit spread into the stand is 30 feet for mistletoeinfected Douglas-fir and 100 feet for infected ponderosa pine (Scott and Schmitt 1996).

Reserving older, infected western larch may be critically important in some stands to provide nest platforms for raptors and long-lasting, high-quality cavity-nester habitat. When selecting overstory western larch as wildlife trees, select those trees most heavily affected by mistletoe and with obvious platforms. Most mistletoe-caused larch mortality is the result of heavy infestations that lead to progressive loss of broomed branches and degradation of the whole crown. Such trees are most likely to produce a high-quality snag, but the infection potential is low because the diminutive crown supports fewer mistletoe plants. If management of understory western larch is an objective, leaving wildlife trees that will produce the fewest mistletoe seeds to infect the understory would be best. Lightly infected larch have been traditionally left as "crop" or "seed-trees," but they could produce more dwarf mistletoe seeds because of their larger, more vigorous crowns.

When selecting infected tree species other than western larch for wildlife use, leaving a patch of trees that contains some trees with brooms in the mid-crown that are large and dense enough to furnish a nesting platform will provide the most benefit. These trees will have a moderate infection rating and will be growing slower than uninfected trees, but they provide good habitat. Trees with brooms in the top third of the crown can be removed to improve stand productivity with limited loss to wildlife. 


\section{Broom Rusts}

Ecological processes and functions--Like dwarf mistletoes, broom rusts cause witches' brooms on their coniferous hosts. Unlike dwarf mistletoes, which are parasitic plants, broom rusts are pathogenic fungi. These fungi require an alternate herbaceous host for completion of their life cycle but can spread in primary host branches without further infection (Ziller 1974).

Little information is published on wildlife uses of brooms caused by broom rusts. American martens in northeastern Oregon commonly use rust brooms for rest sites (fig. 27) (Bull 1995). Thirty-four of 56 flying squirrel dens were in rust brooms in interior Alaska (Mowrey and Zasada 1984). Frank Hawksworth speculated that several reports of wildlife use of mistletoe witches' brooms documented by wildlife biologists are actually rust brooms. This speculation is based on the reports of unlikely hosts for dwarf mistletoes or geographical locations out of range for a particular hostmistletoe relation (Hawksworth 1992). Nonetheless, rust brooms probably serve the same functions as dwarf mistletoe brooms. Broom rusts are not as prevalent in interior Columbia River basin forests as dwarf mistletoes are, and because of differences in infection biology, care should be taken to differentiate them from dwarf mistletoes in selecting wildlife trees.

Infection process-Spruce broom rust (Chrysomyxa actosathyli) infects Engelmann spruce (figs. 28 and 29). The herbaceous alternate host is kinnikinnick (Arctostaphylos uva-ursi). Fir broom rust (Melampsorella caryophyllacearum) infects grand and subalpine firs. The herbaceous alternate hosts are chickweeds (Stellaria spp. and Cerastium spp.). The conspicuous orange-yellow brooms on their coniferous hosts are apparent, especially in the summer when affected needles are covered with blisters filled with yellow or orange spores. The discolored needles are cast in fall, and a new flush of needles appears the next spring. Brooms grow perennially and may be older than 30 years. Broom rusts often are associated with spiketops, dead branches, stem deformities, and breakage, but host mortality is rare.

Selecting trees-Because of the difference in the infection process, retention of trees with broom rusts does not have the potential negative management implications associated with unlimited retention of dwarf mistletoes. Trees with the largest brooms are immediately suitable for wildlife use. Because small brooms often will continue to grow, trees with all sizes of brooms may be retained for future use. Retaining infected trees is advisable whenever possible because broom rusts are uncommon.

\section{Elytroderma Disease}

Ecological processes and functions--Elytroderma disease of pines is caused by the needle cast fungus Elytroderma deformans. It is most prominent in ponderosa pine in the interior Columbia River basin but is occasionally found on lodgepole pine (Childs and others 1971). Heavily infected trees are defoliated because of "cast" or dropping of infected needles. Brooms formed by this fungus (fig. 30) can resemble the brooms formed by dwarf mistletoes.

Little wildlife use of brooms formed by Elytroderma has been documented, because the brooms are not commonly distinguished from those formed by dwarf mistletoes. Great homed owls have been observed nesting in Elytroderma brooms (Bull 1996b) (fig. 31). Presumably, other raptors that nest in brooms formed by dwarf mistletoes also would nest in brooms formed by this fungus.

Infection process-Spores of the causal fungus are released in late spring and early summer from tiny fruiting bodies borne on infected needles (fig. 32). Under conditions of rain or free moisture, the airborne spores germinate and infect the young needles of a susceptible host. The fungus spreads throughout the needles and into the twigs. The infection within the twigs spreads into the growing tips and buds, where it causes brooming and deforms future growth. Needles infected the previous year are cast after turning bright red and then fading to straw color. Severe infection will produce thin, ragged crowns and growth reduction of the tree. Tree mortality occasionally results from heavy defoliation. Light infection of 25 percent or less of the crown causes little reduction in tree growth or survival.

Selecting trees-In ponderosa pine, Elytroderma brooms may be distinguished from mistletoe brooms by the presence of fruiting bodies on the needles of the broom, by the accumulation of dead needles in the broom structure, and by the absence of the dwarf mistletoe plants usually associated with dwarf mistletoe-caused brooms. Infected needles lose their bright red-brown color gradually through summer in Elytroderma brooms. The brooms tend to be more compact and spherical than those caused by dwarf mistletoes, and the ends of twigs turn up.

Management implications-When selecting broomed trees in stands for retention where ponderosa pine regeneration is a management objective, selecting Elytrodermainfected trees may be preferable to selecting dwarf mistletoeinfected trees, when they are available. Elytroderma may be less debilitating to the host tree, and its dense brooms may sometimes be more valuable to wildlife than are the more open brooms of dwarf mistletoes. When Elytrodermainfected trees are available, select trees that have 25 percent or less crown infection. 


\section{Review}

- Brooms serve as food and hiding and nesting habitat for both invertebrates and vertebrates. Brooming is most often caused by dwarf mistletoes, rust fungi, or Elytroderma disease.

- Dwarfmistletoe brooms are most useful to some wildlife if they form a platform, although the shoots and seeds of the dwarf mistletoe plant also are eaten by wildlife.

- Dwarf mistletoes can spread to the point that they adversely affect wildlife habitat by limiting tree growth, causing extensive tree mortality, and increasing risk of crown fire. To limit spread, dwarf mistletoe-infected trees reserved for wildlife can be grouped and surrounded by a buffer of trees that are nonhosts or by a treeless buffer. Buffers slow the spread into the surrounding stand.

- Brooms caused by rusts offer useful nesting and resting habitat. These brooms are most commonly found on Engelmann spruce and subalpine fir.

- Reserving trees with brooms caused by rusts or Elytroderma disease may provide broom habitat without the same concerns of spread associated with reserving dwarf mistletoe-infected trees.

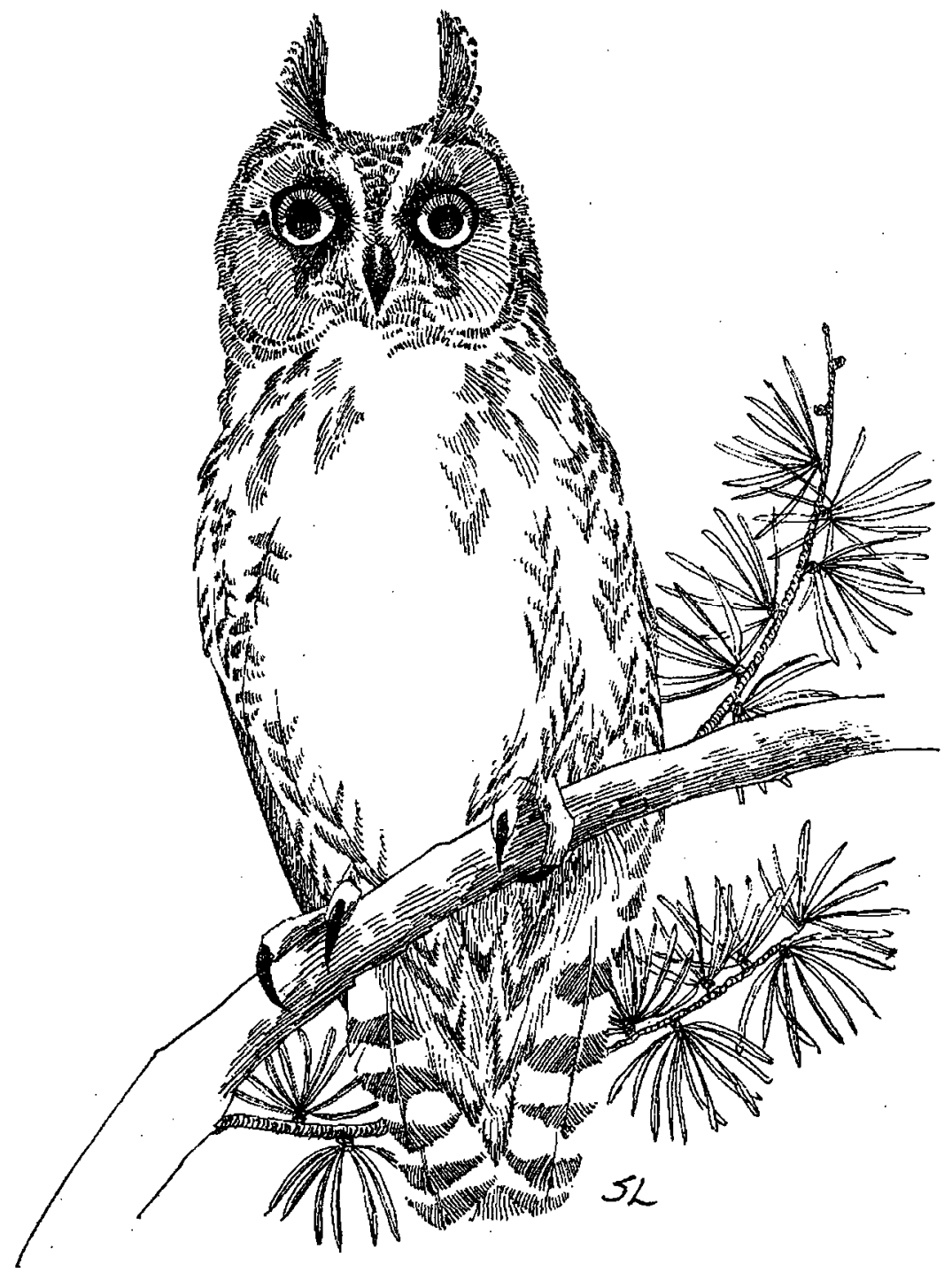




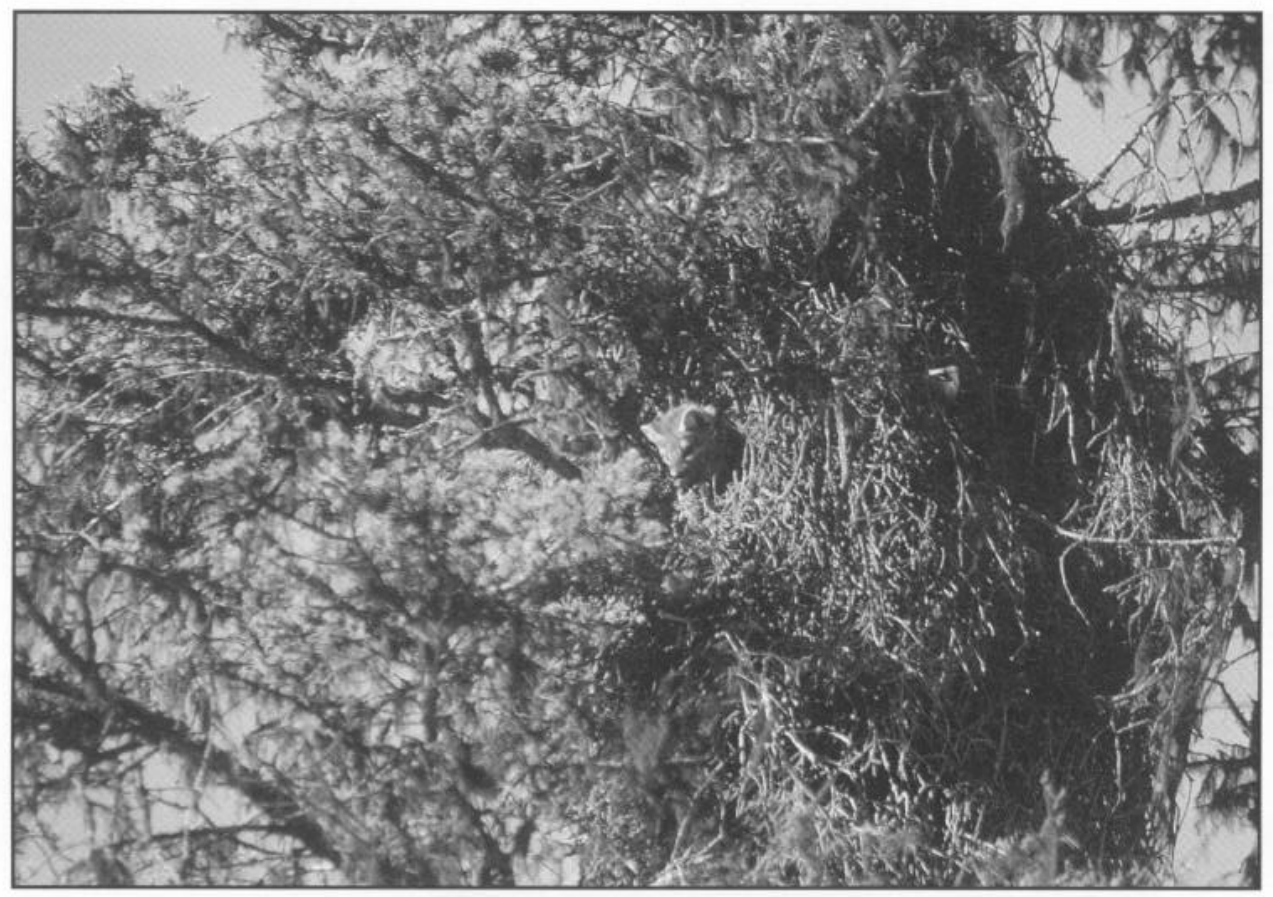

Figure 27-American marten using a broom rust in Engelmann spruce as a resting site.

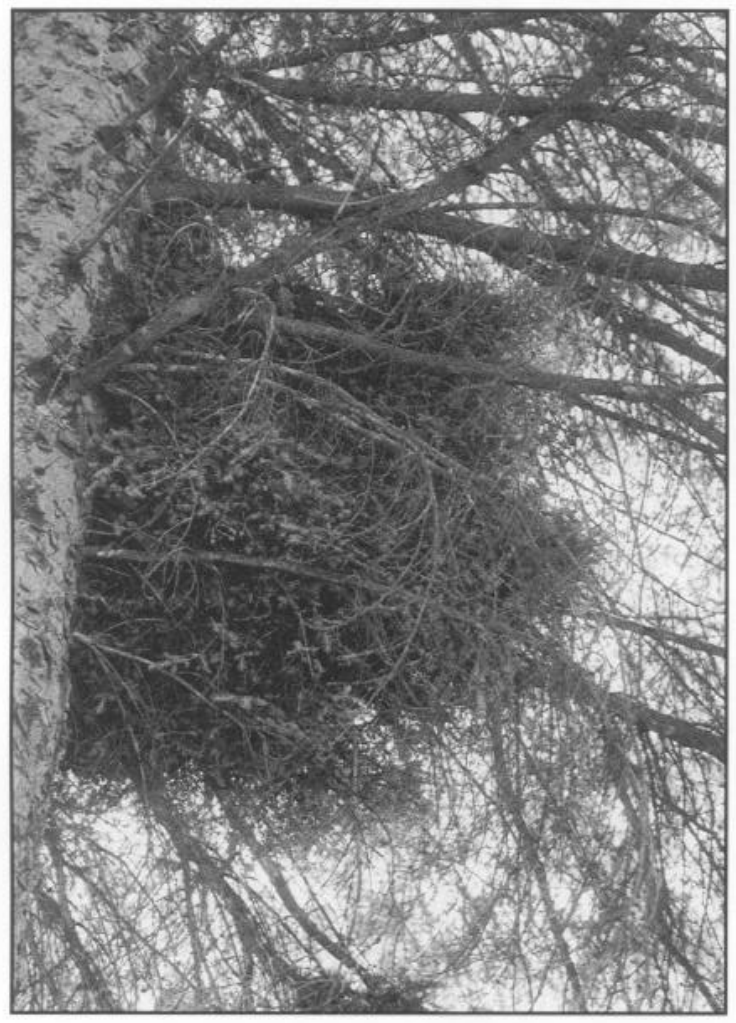

Figure 28-Spruce broom rust on Engelmann spruce.

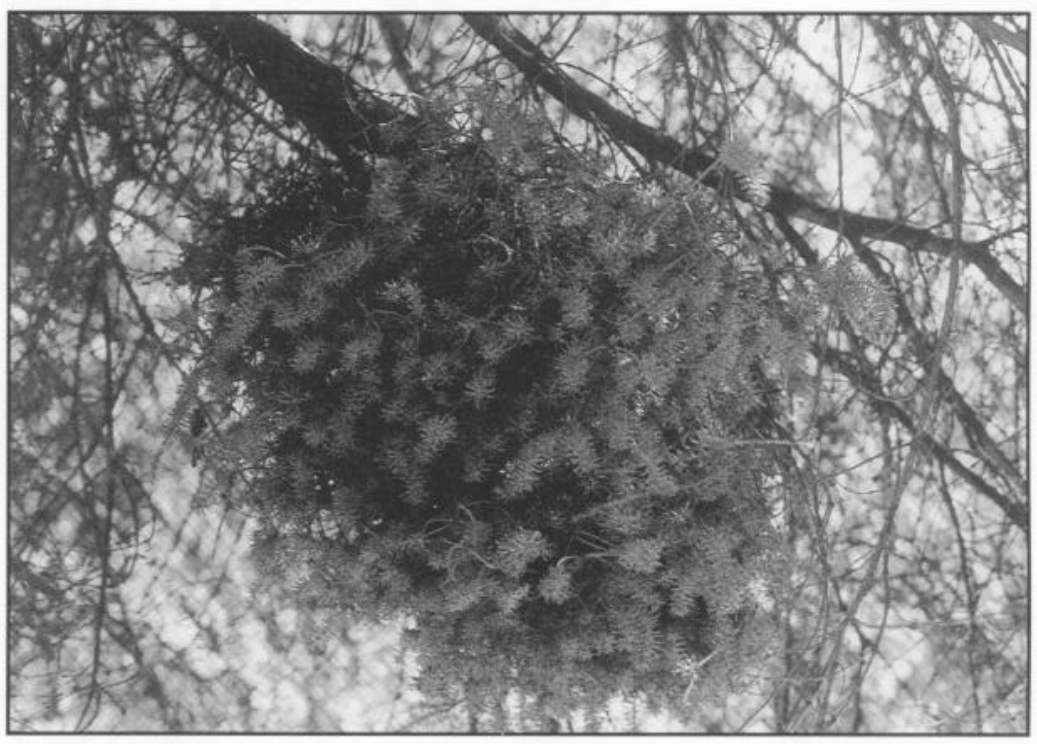

Figure $29-$ Brooms caused by spruce broom rust are most conspicuous during the summer when yellow-brown spores are present. 


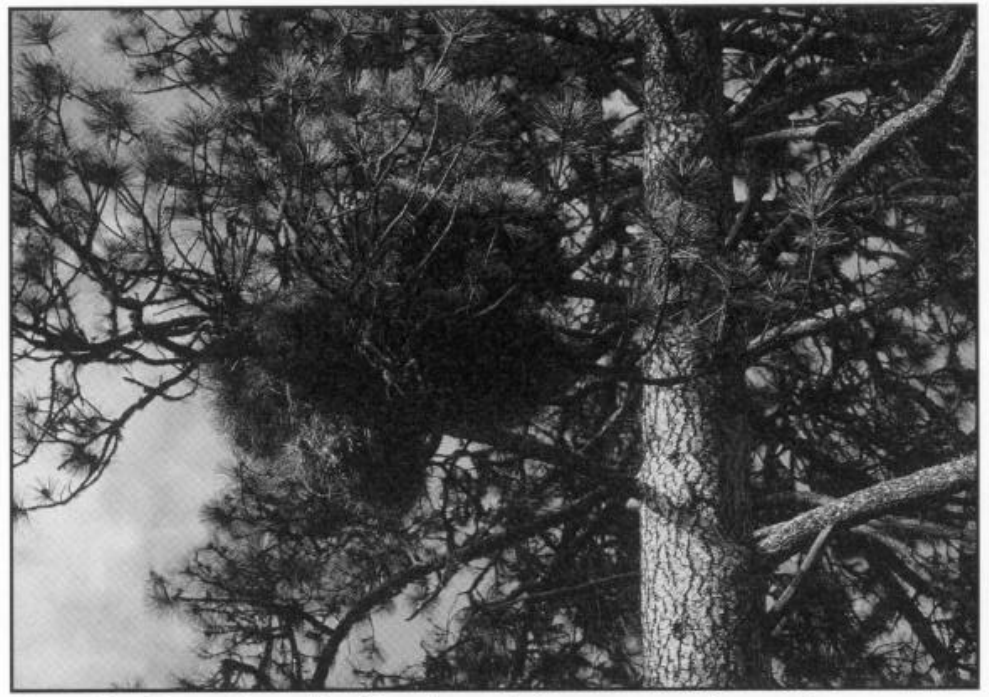

Figure 30 - Broom formed by Elytroderma deformans on ponderosa pine.

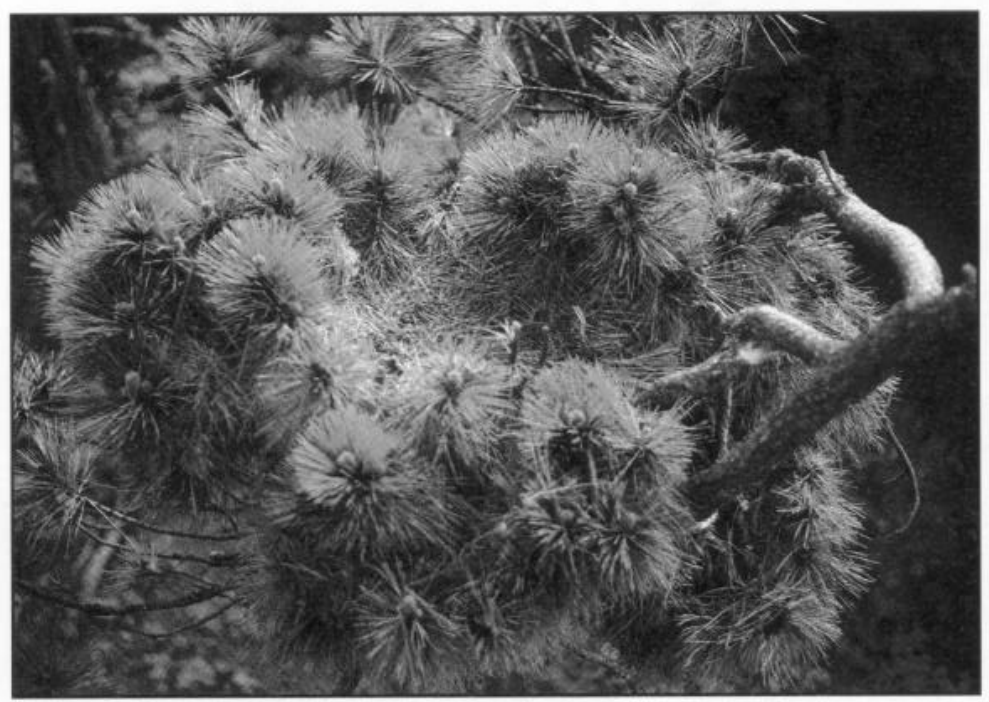

Figure 31 -Elytroderma broom used by great horned owls for nesting.

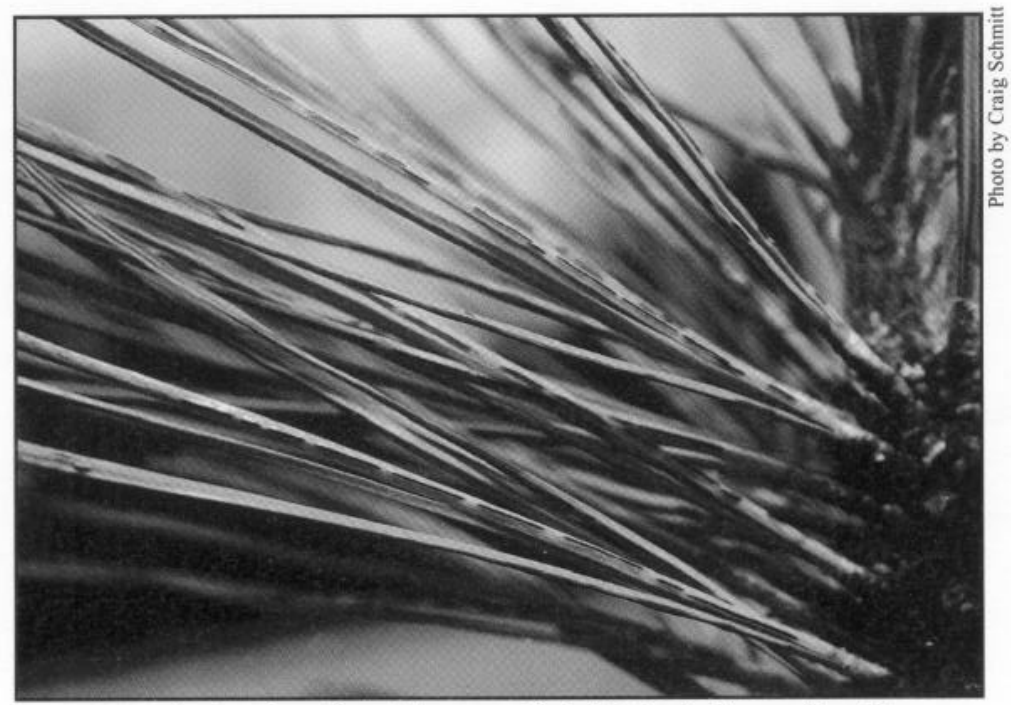

Figure 32-Discolored needles with narrow black fruiting bodies are found in Elytroderma brooms. 


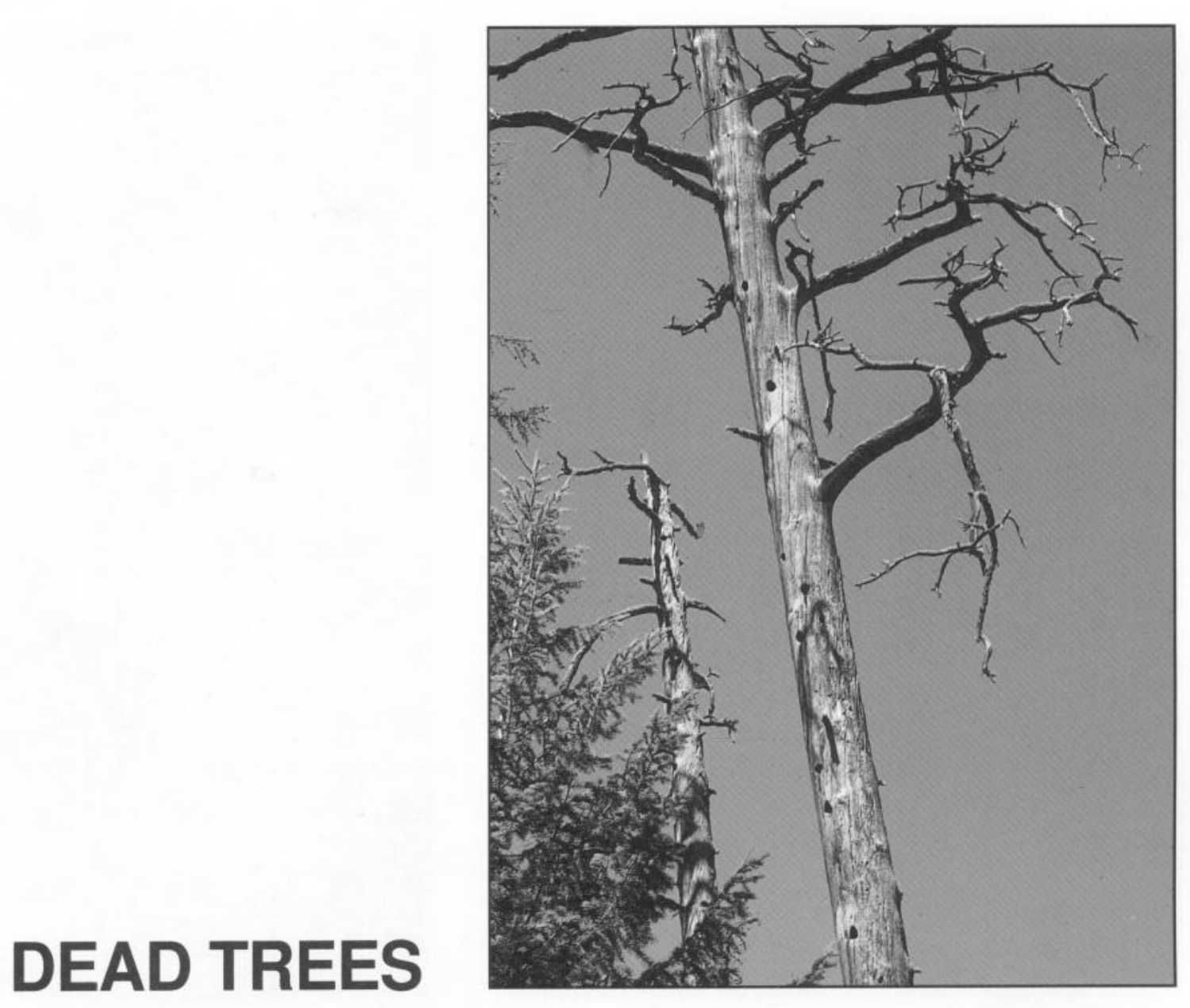

\section{Ecological Processes and Functions}

Snags, or standing dead trees, are an essential component in forests, and many wildlife species depend on them for survival. Patches or even entire stands of trees have died across the landscape throughout the evolutionary history of forest ecosystems. The events and decay processes that create these dead trees maintain the snag resource through time.

Several factors or combinations of factors can be responsible for tree mortality, including insect outbreaks, diseases, fire, drought, and flooding. How the tree dies can determine its use by wildlife. Any snag can be used as a perch site, but for a snag to be a suitable site for a cavity, the wood typically must be softened by decay (fig. 33). Some sources of tree mortality are more conducive to the introduction of decay than others. For example, fire can case-harden snags and make them resistant to decay.

Specific types of mortality agents, such as fire, disease, or insects, may target different tree species and age classes; thus a mix of snag species and sizes occurs across the landscape. Although each wildlife species usually has a tree species preference for foraging or nesting, it often uses a variety of tree species. The wildlife not adapted to using a variety of snag species are also those that are most restricted in range and in the greatest danger of extirpation.
Many wildlife species depend on dead trees for nesting, roosting, denning, foraging, resting, or shelter. Woodpeckers and nuthatches, known as primary cavity nesters, have the ability to excavate cavities in snags where they nest and roost (figs. 34 and 35). Because woodpeckers usually excavate a new nest cavity each year, old nest cavities are available for many secondary cavity users. Secondary cavity users, which include many species of birds and mammals, cannot excavate a cavity but use existing ones for nesting, denning, or shelter. Thomas and others (1979) list species that use snags and logs in the Blue Mountains in northeastern Oregon.

The space behind loose bark on snags also provides nest sites for brown creepers (Certhia americana) and roost sites for bats. Brown creepers wedge a nest of grass and twigs in the space between the bole and its loose bark. Loose bark also provides bats with a dry, sheltered roosting place (fig. 36). Although bats roost under loose bark, recent studies have shown that a high percentage of bat roosts are in woodpecker cavities. Steeger and Machmer (1996) found that 54 percent of 28 bat roosts were in vacated woodpecker cavities, 32 percent in natural cavities, 11 percent in cracks, and the remainder under loose bark. 


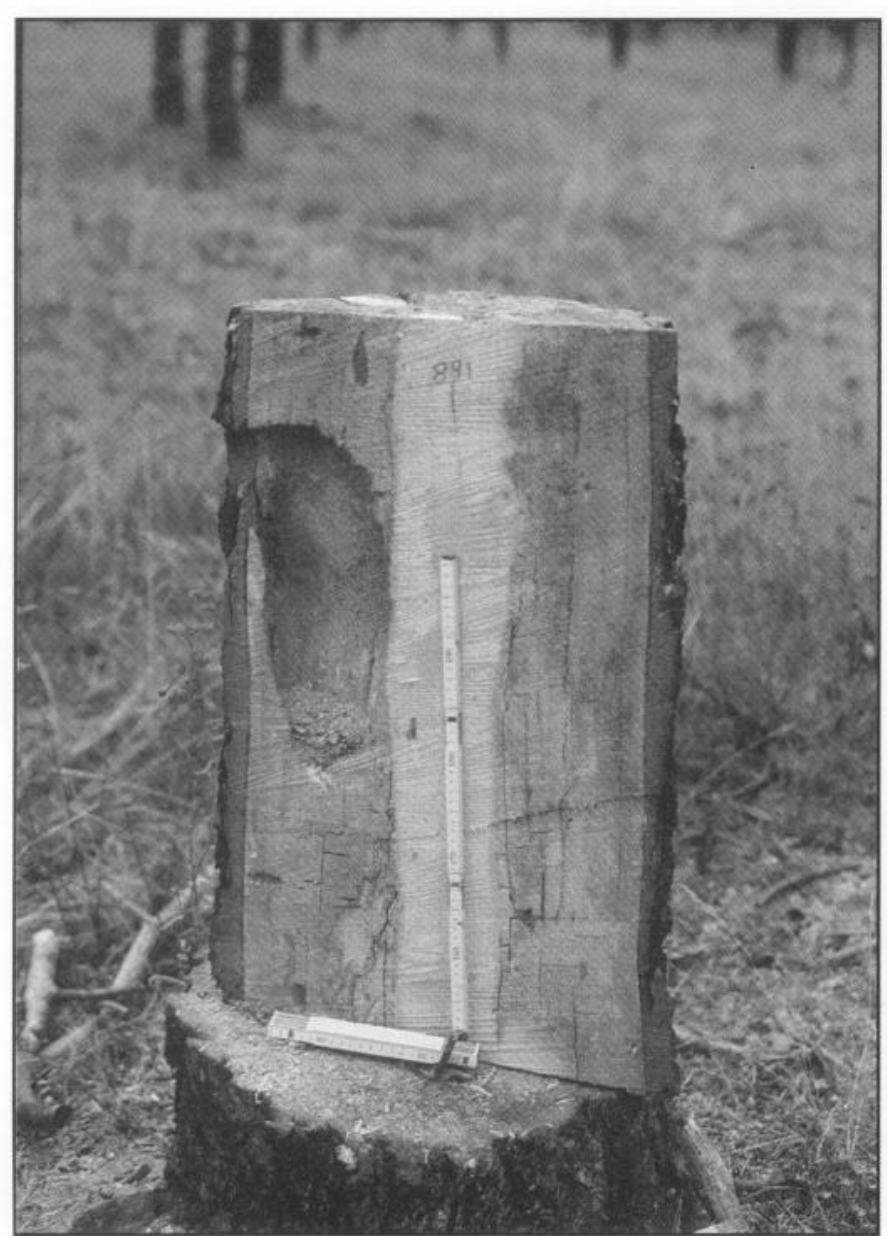

Figure 33-A woodpecker nest cavity excavated in the decayed sapwood of a ponderosa pine snag; the heartwood can be too sound for excavation. Most other tree species have sapwood that is too thin to accommodate a nest, so nests are usually excavated in the decayed heartwood.

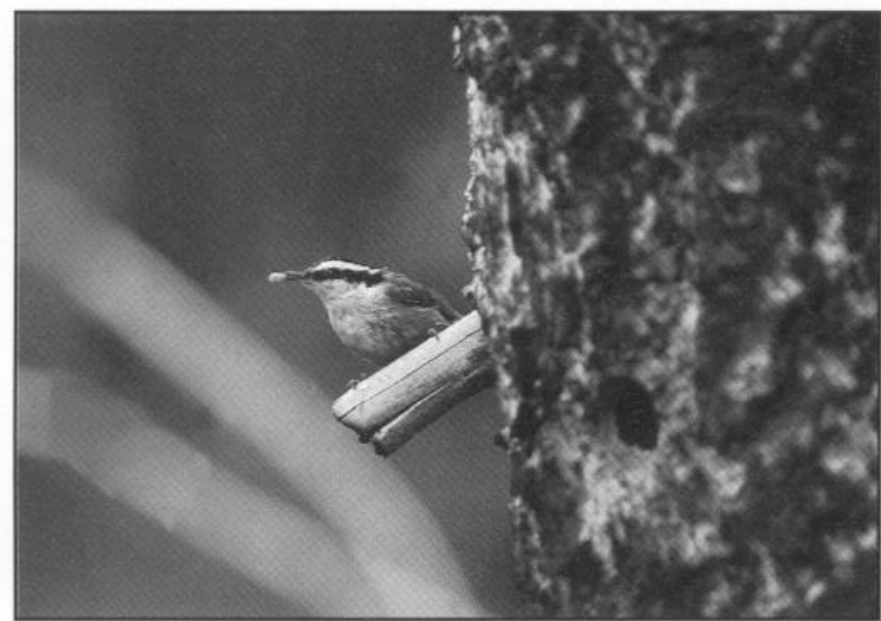

Figure 35-The red-breasted nuthatch (Sitta canadensis) requires extensively decayed wood for cavity excavation.

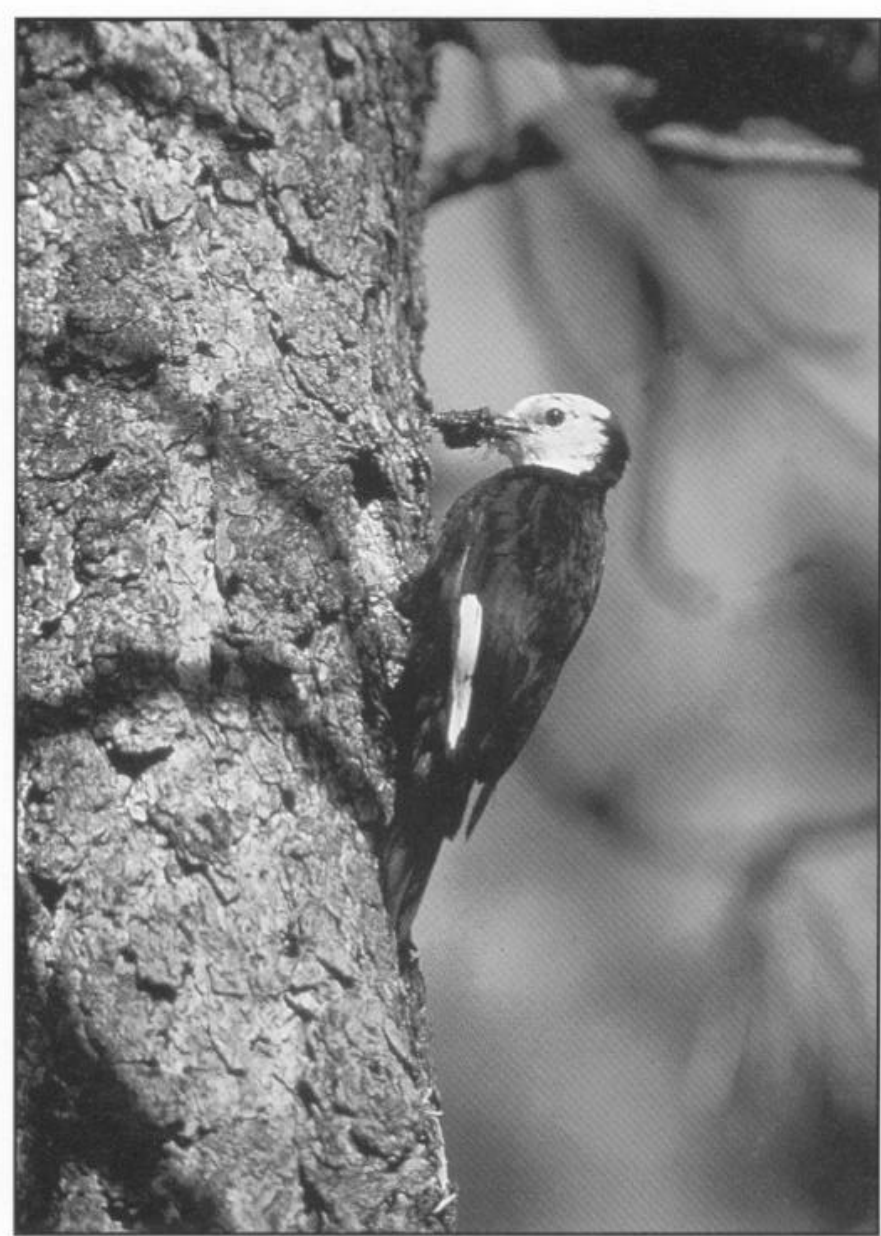

Figure 34 -Woodpeckers, including this white-headed woodpecker, typically excavate nest cavities in dead trees.

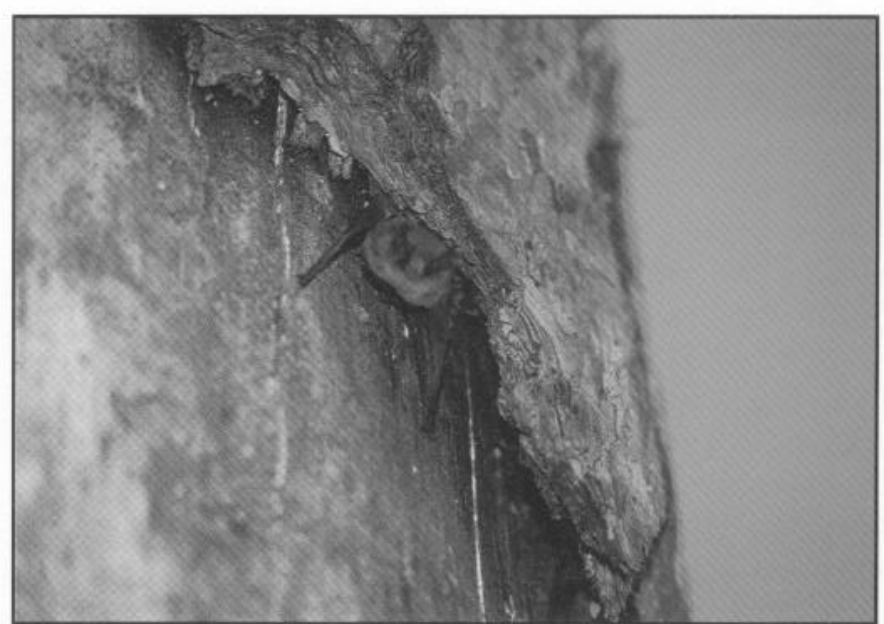

Figure 36 - Bats often roost under loose bark and in woodpecker cavities. 
Because owls do not build nests, the smaller owls use existing cavities (fig. 37), and the larger forest owls use platforms. Snags with broken tops often provide nest platforms for great gray (fig. 38) great horned, and barred (Strix varia) owls.

Snags are used by some woodpeckers for foraging. Pileated woodpeckers forage extensively in the interior wood of snags in search of carpenter ants (Camponotus spp.) (fig. 39). Hairy (Picoides villosus), black-backed, three-toed ( $P$. tridactylus), and white-headed woodpeckers all forage extensively on dead trees, particularly on insects in the bark, cambium, and sapwood (fig. 40).

\section{Decay Process}

Tree species, size, and percentage of sapwood influence the rate of decay, as do environmental factors such as climate, elevation, and aspect. The group of decay fungi that colonize the sapwood of newly dead trees usually cause rapid decay. Trees killed by root disease, mistletoe infection, insect defoliation, drought, or flooding are likely to be colonized by sapwood rotting fungi and infested by bark beetles within 2 years after death. Trees killed by bark beetles often have considerable sapwood decay within a few years. Once the sapwood decay fungi (fig. 41) have decayed the newly dead sapwood entirely, they often are replaced by saprophytic fungi, a large group of general scavengers (figs. 42 and 43). The saprophytic fungi continue to decompose the sapwood and then proceed at a slower rate into the heartwood. Heart-rot fungi that may already be present in the trees at the time of death usually are relatively inactive and contribute little to the deterioration of the dead tree. The thin layer of decayed sapwood in Douglas-fir (fig. 44) contrasts with the thick layer of sapwood in ponderosa pine (fig. 33). Cavity nesters readily excavate cavities in the thick sapwood of ponderosa pine snags because it is softened by decay.

Stain-causing fungi (that is, "blue stains") often are associated with beetle and woodborer infestation. The stain fungi do not cause decay, or softening, of the wood. They invade and use the cell contents, in contrast to the decay fungi, which use the structural components of the cell wall.

Trees killed by root disease typically add to the snag component for only a short time before they fall over. Root disease is caused by a group of decay fungi that infect roots and spread through root contact. Root disease pockets start in a tree or stump and tend to spread outward in all directions (Bega 1978). Typically, the tree dead for the longest time will be in the center and fringed by dying or recently dead trees on the outeredge (fig. 45). Although snags created by root disease may not stand for a long time, the expansion of the center provides a continuous supply.

The rate of decay in trees killed by fire is influenced by the intensity of the fire, the rate of tree growth before the fire, the tree species, and its size. The sapwood and heartwood of true firs killed by fire deteriorates faster than in other species. The thin layer of sapwood in fire-killed Douglas-fir deteriorates rapidly, but the heartwood decays more slowly than in other species. The extremely thick sapwood of ponderosa pine, which ordinarily constitutes from 50 to 75 percent of the tree's volume, is more resistant to general deterioration than is the sapwood of other species. The sapwood of fire-killed ponderosa pine begins to soften in the third year after death (Kimmey 1955).

\section{Selecting Snags}

Characteristics to consider when selecting snags for retention are tree species, diameter, height, structural class, and proximity to other snags and live trees. The kind of snags retained depends on management objectives and the snag resource available. For example, if the objective is to leave rest sites for martens, then hollow grand fir and western larch snags would be retained. If the objective is to provide nesting habitat for large forest owls, large-diameter snags with broken tops would be retained. To provide habitat for all cavity nesters, a variety of tree species would be retained for both foraging and nesting.

Tree species-Retention of snag species depends on the objective and the geographic area. In Montana, McClelland and others (1979) found that western larch, ponderosa pine, paper birch, and quaking aspen are preferred for nesting by cavity-using birds. Douglas-fir was used for foraging rather than nesting. Another study in Montana showed that rednaped sapsuckers used paper birch (5 1.6 percent of nest trees), western larch (35.5 percent), quaking aspen (6.5 percent), and Douglas-fir (6.5 percent) for nest sites (Tobalske 1992). In interior cedar-hemlock (Tsuga heterophylla) stands in southern British Columbia, 85 percent of 237 nests of cavity-using birds, 14 cavity-using mammals, and 31 bat nurseries were in Douglas-fir, quaking aspen, paper birch, and western larch (Steeger and Machmer 1995). All nests excavated by black-backed ( $\mathrm{n}=35$ nests) and three-toed $(\mathrm{n}=20)$ woodpeckers in a study in central Oregon were in lodgepole pine (Goggans and others 1988).

In central Oregon, Bate (1995) reported that woodpeckers prefer ponderosa pine snags over lodgepole pine snags for nesting. Dixon (1995) also reported a nesting preference for ponderosa pine snags by white-headed woodpeckers. In northeastern Oregon, ponderosa pine and western larch were favored as nest trees by pileated woodpeckers and Williamson's sapsuckers; most nest trees used by hairy and black-backed woodpeckers and northern flickers were in ponderosa pine trees (Bull 1986). In east-central Washington, woodpeckers selected ponderosa pine and Douglas-fir for nest cavities and western larch and Douglas-fir for feeding (Bevis 1996).

When retaining snags for cavity nesters, ponderosa pine, western larch, quaking aspen, and paper birch are the favored species in many localities. Suitability of other species must be determined based on known wildlife use and decay conditions characteristic of each tree species for each locality. For hollow snags, grand fir is the best species to retain in the interior Columbia River basin.

Tree size and height-Typically, large-diameter snags (more than 20 inches d.b.h.) stand the longest, can accommodate nest cavities of any woodpecker species, and provide 


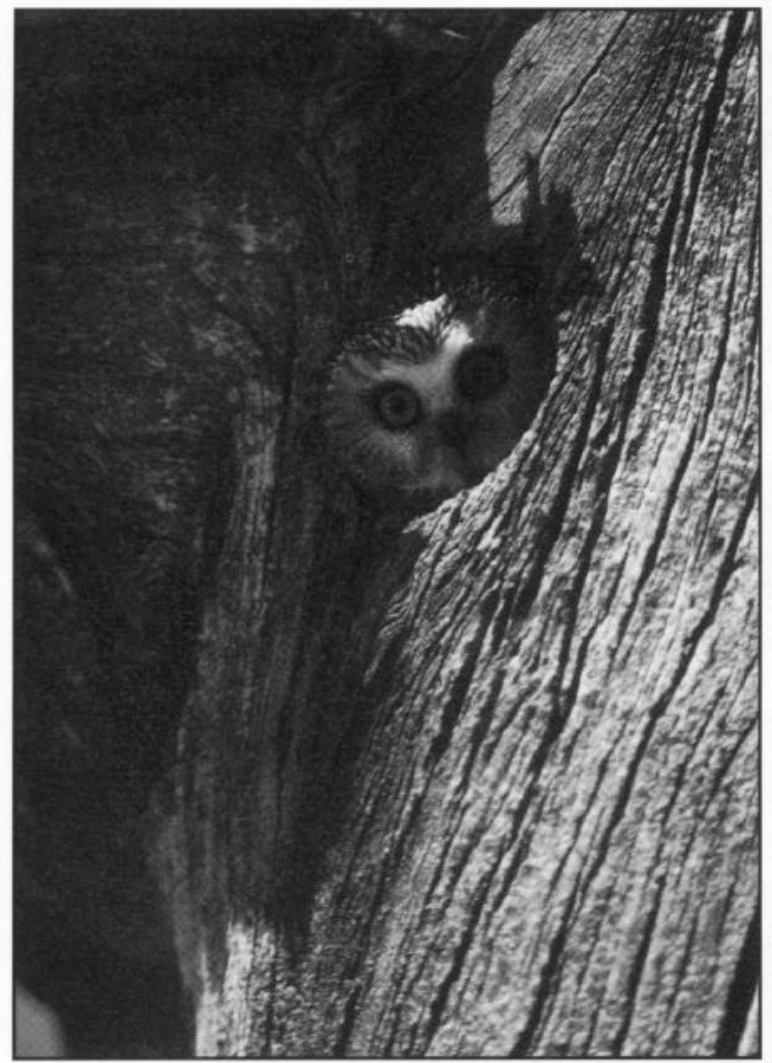

Figure 37-Small owls, like this saw-whet owl, require an existing cavity for nesting.

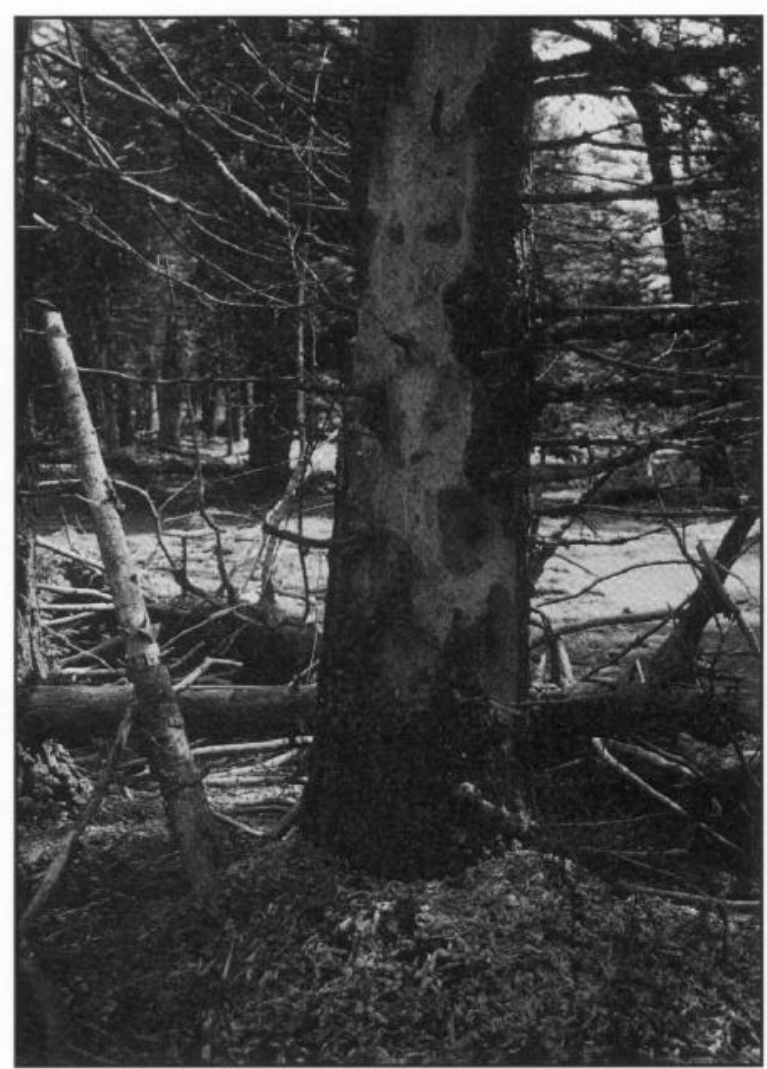

Figure 39-Pileated woodpeckers, in search of carpenter ants and other invertebrates, excavate large rectangular cavities in the heartwood of some snags and logs.

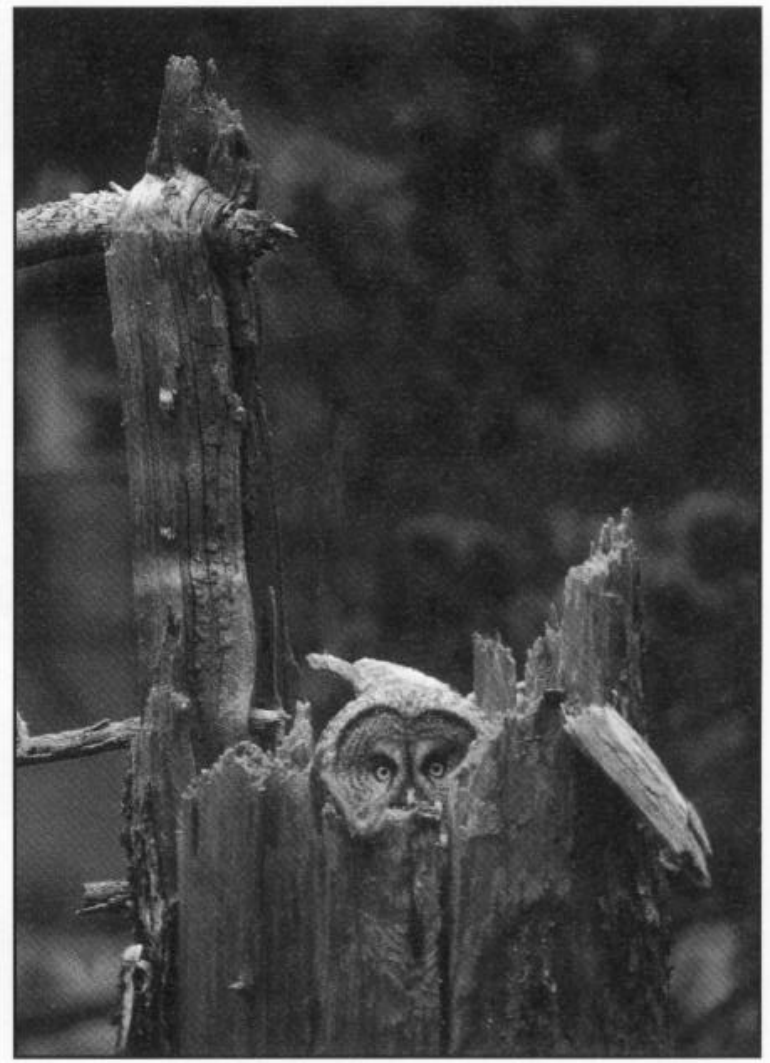

Figure 38-Great gray owls, as well as some other large owls, may use the broken tops of snags for nesting.

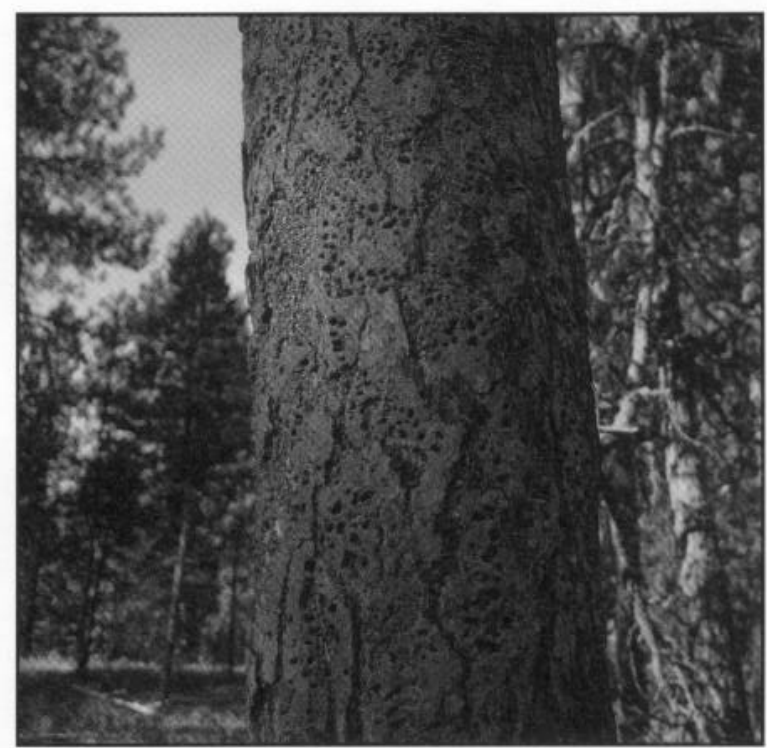

Figure 40-Hairy, black-backed, and three-toed woodpeckers forage for invertebrates in the bark of snags. 


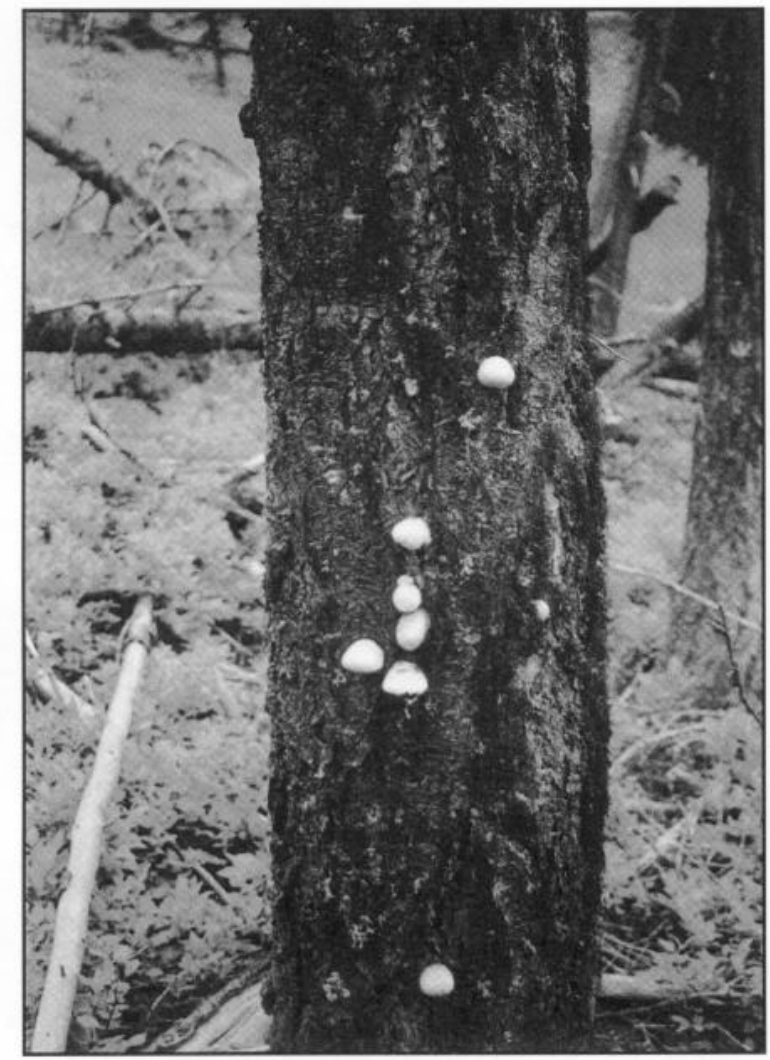

Figure 41 - The pouch fungus (Cryptoporus volvatus), a sapwood decay fungus, typically invades and fruits on trees soon after their death (up to, but not longer than 18 months).

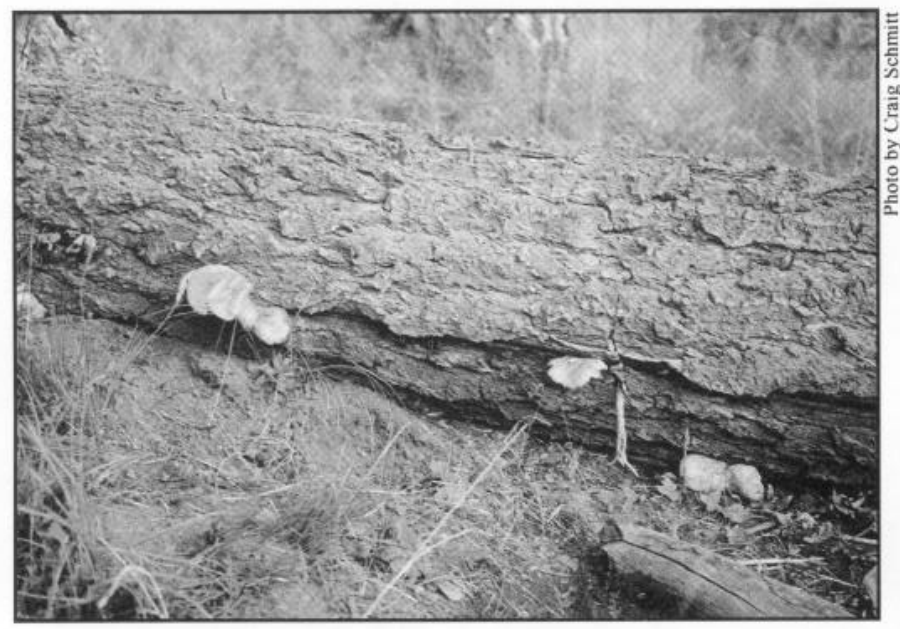

Figure 43-Fruiting bodies of many other saprophytic fungi commonly are seen on logs, because the moisture conditions are conducive to decay and formation of fruiting bodies.

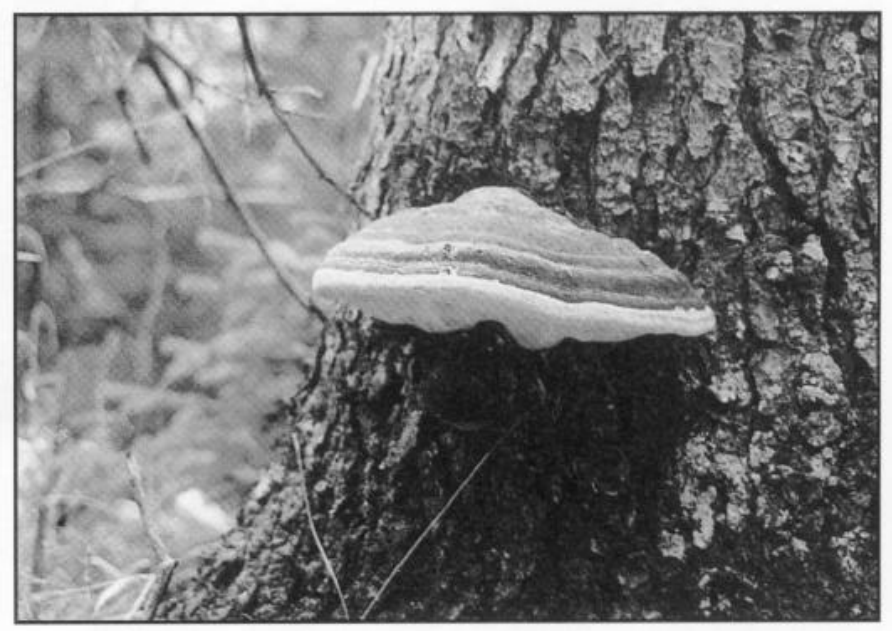

Figure 42-The red belt fungus (Fomitopsis pinicola), a saprophyte, is one of the most common fruiting bodies found on snags and logs.

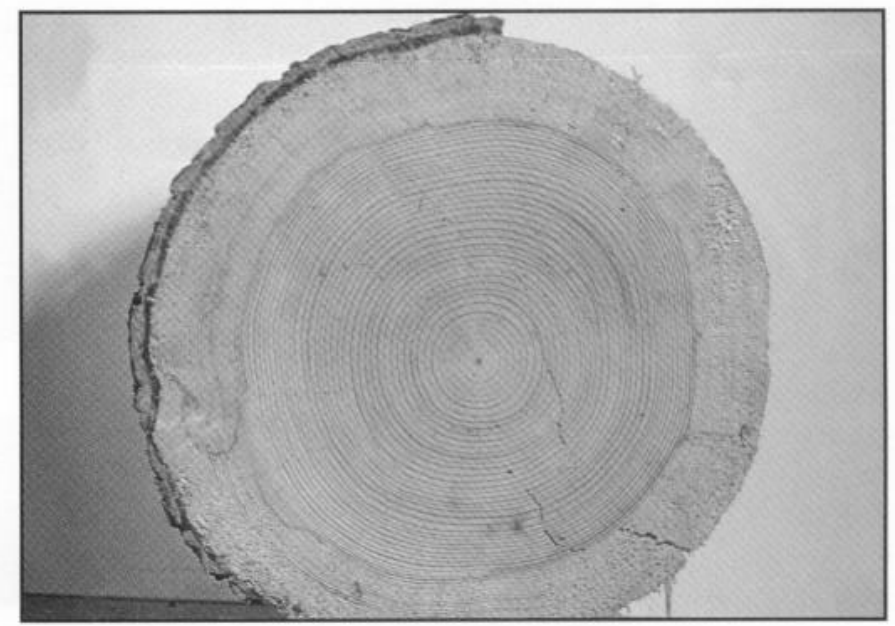

Figure 44-A Douglas-fir killed by insects; the sapwood is extensively decayed, and the heartwood is sound. 


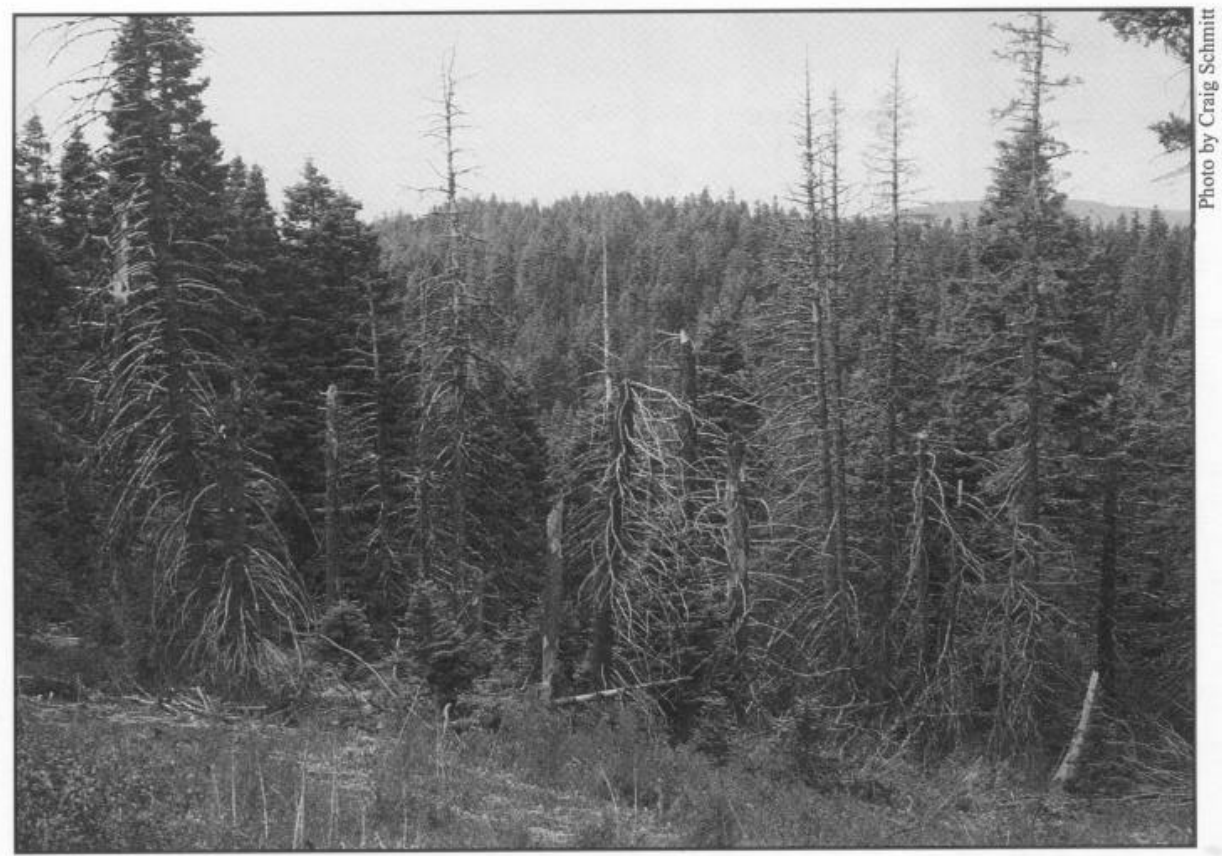

Figure 45-Root diseases start in a tree or stump and spread slowly outward in all directions. Disease pockets typically have the oldest snags in the center with a fringe of dying trees. Trees in root disease pockets may not stand long because of root decay.

the most stable microclimate because of the wood thickness. Preference for large-diameter snags has been well documented for the pileated woodpecker, hairy woodpecker, northern flicker, and Williamson's sapsucker in northeastern Oregon (Bull 1986); for the white-headed woodpecker in central Oregon (Dixon 1995); for woodpeckers in ponderosa pine forests in central Oregon (Bate 1995); for pileated woodpeckers in Montana (McClelland and others 1979); and for cavity nesters as a group in burned ponderosa pine forests of southwestern Idaho (Saab and Dudley 1997).

Thickness of the wood surrounding a cavity is important for thermal regulation and protection from predators.

Woodpeckers that nest or roost in small trees may have only a thin shell of sapwood or only bark surrounding their cavity, which provides minimal insulation and protection against predators. Black bears, martens, or raccoons (Procyon lotor) can break into a nest cavity if the shell surrounding it is too thin.

Although most cavity nesters select for the largest snags available, a few species seem to prefer smaller trees in some localities. Downy (Picoides pubescens) and three-toed woodpeckers prefer smaller trees for nesting in Montana (McClelland and others 1979). Black-backed woodpeckers use relatively small, hard snags in areas with stand-replacing fires in ponderosa pine/Douglas-fir stands in Idaho (Saab and Dudley 1997).

Height is also important in selecting snags because different species of woodpeckers prefer to nest at specific heights (Thomas and others 1979). Pileated woodpeckers typically nest 30 to 50 feet above the ground. To have enough girth at these heights to accommodate cavities that are 8 to 10 inches wide and 24 inches deep takes a large tree. Although some woodpeckers will nest within 3 feet of the ground, these nests are more vulnerable to predators ( $\mathrm{Li}$ and Martin 1991) because they are easily detected.
In addition, the larger and taller snags have greater volume and are more likely to have the appropriate decay conditions at the preferred height than are smaller trees. Therefore, when possible, managers should retain the largest snags available.

Snag structural classes-The physical appearance of snags is largely indicative of the condition of the wood, so appearance is the basis for snag selection. Thomas and others (1979) presented nine successional stages from the time of death to total decomposition of a tree. Here we present a simplification of the successional stages and classify all snags into three structural classes (figs. 46 and 47). When retaining snags, all structural classes should be represented across the landscape.

Snag structural class 1 represents those snags that have recently died, typically have little decay, and retain their bark, branches, and top. These snags are used extensively by woodpeckers for foraging in and under the bark.

Snag structural class 2 represents those snags that show some evidence of decay and have lost some bark and branches, and often a portion of the top. Most nesting by woodpeckers, as well as extensive foraging in and under the bark and in the interior of the wood, is in this structural class. Remaining bark that has loosened can provide nest sites for brown creepers or roost sites for bats.

Snag structural class 3 represents those snags that have extensive decay, are missing the bark and most of the branches, and have a broken top. Structural classes for grand fir and Douglas-fir must be modified to some degree because they tend to retain their bark. Foraging in the interior wood is the primary activity in these extensively decayed snags. Secondary cavity users also may nest in existing cavities originally excavated by woodpeckers. Weaker excavators like northern flickers and Lewis' woodpeckers (Melanerpes lewis) excavate nests in extensively decayed wood characteristic of this structural class. 


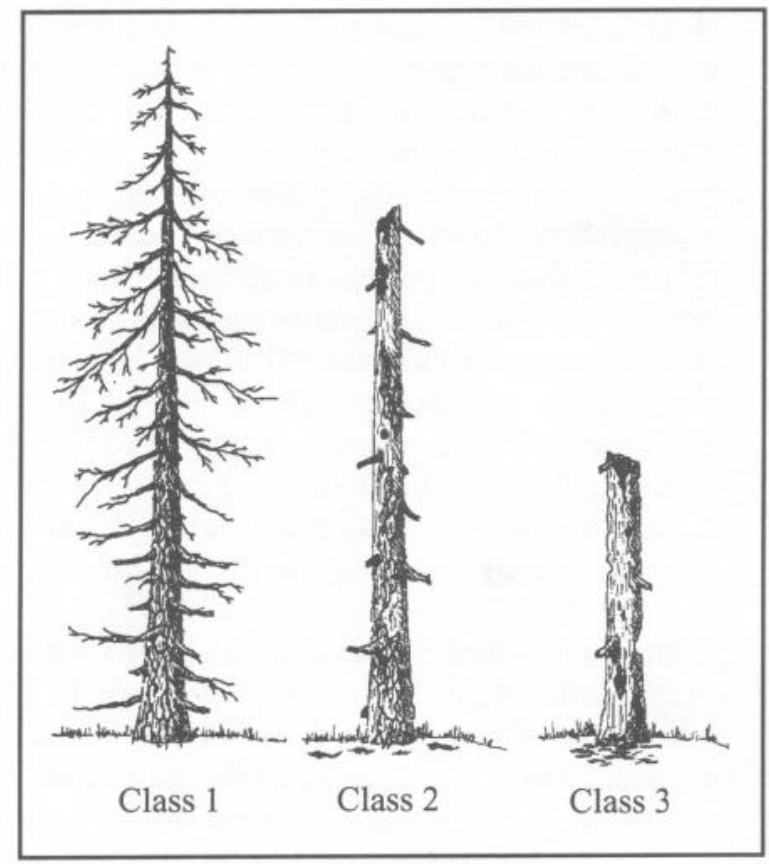

Figure 46-Three structural classes of dead trees.

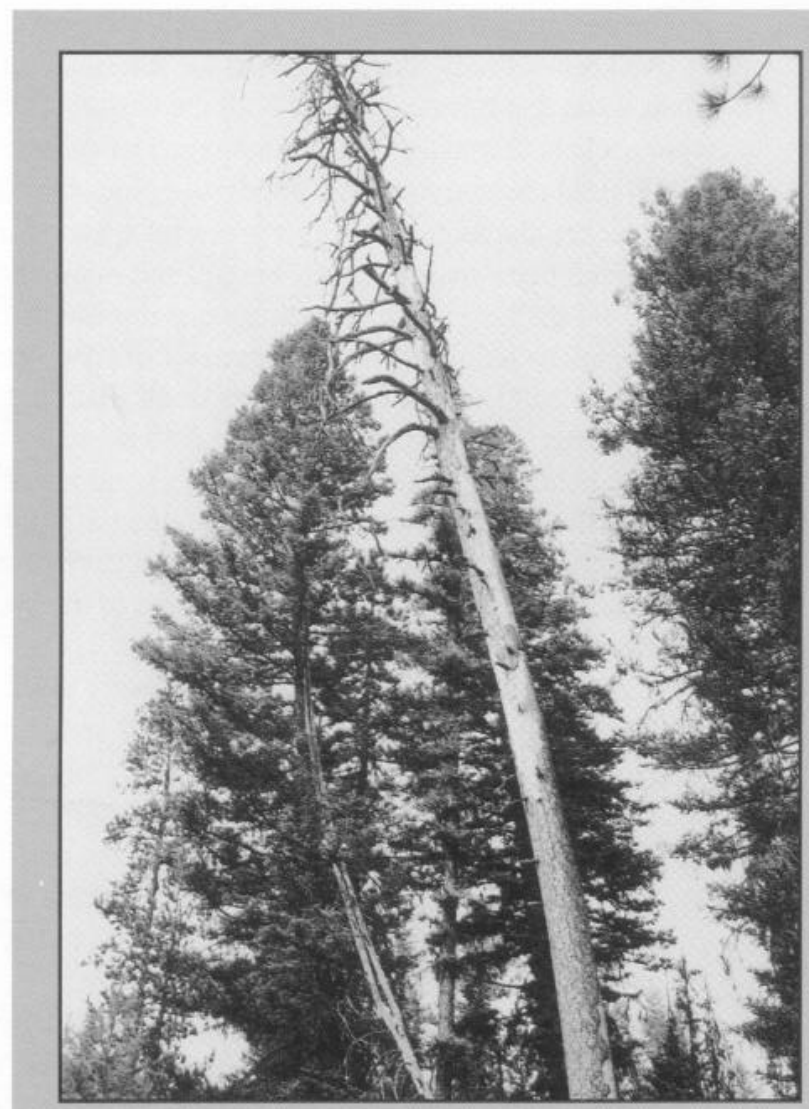

Class 2

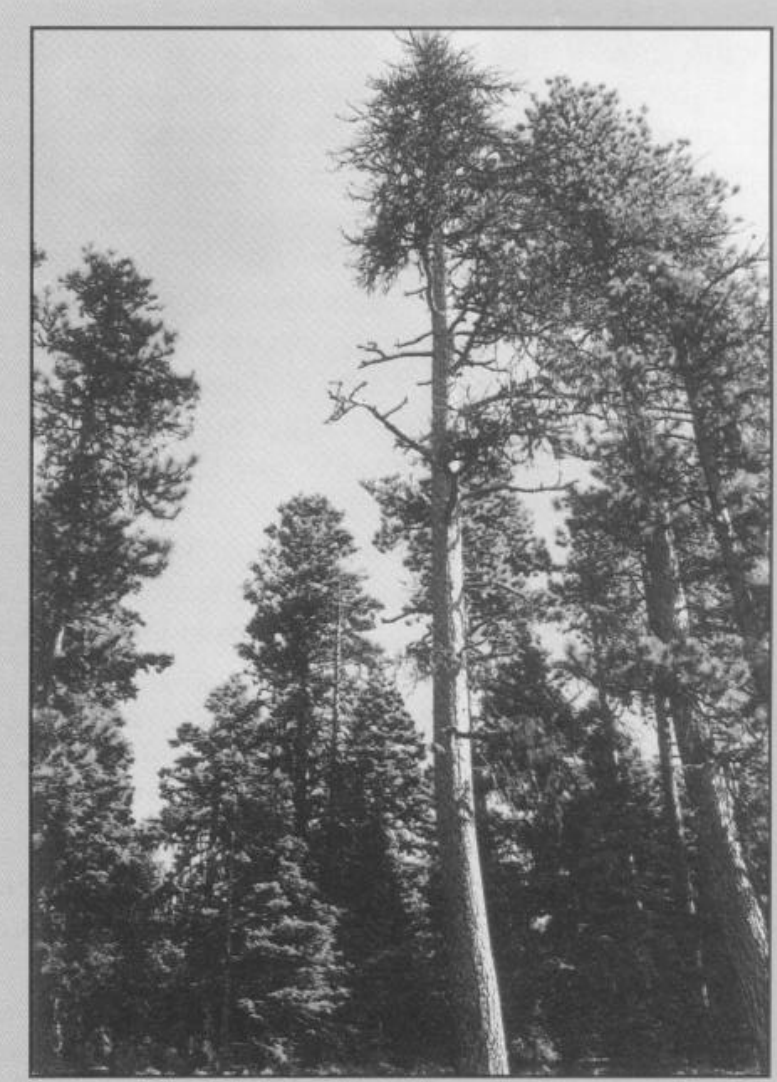

Class 1

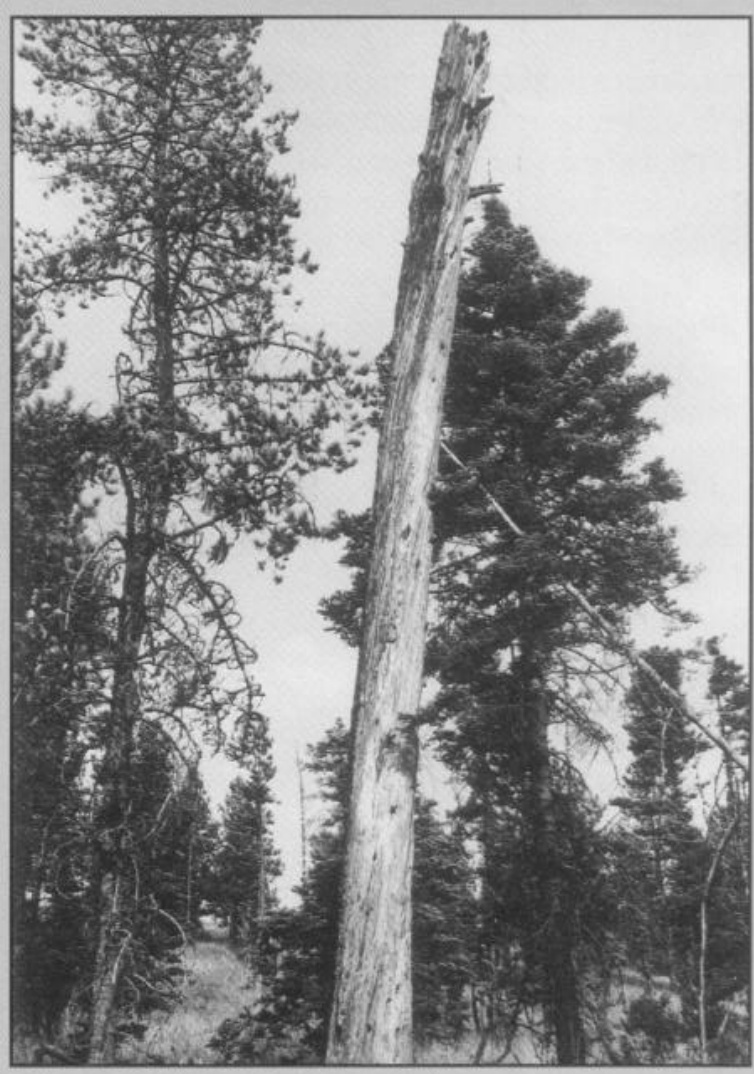

Class 3

Figure 47-Three structural classes of dead trees. 
Snag distribution -- Snags can either be left in clusters or scattered across the landscape, although where to retain them depends largely on where they currently are. Typically, snags are in clumps naturally because the agents of disease, insects, fire, or flooding that kill many trees act in a localized area. Clusters of snags may be easier to protect during management activities than snags evenly distributed across the landscape. Worker safety is an issue when harvesting adjacent to snags. Retaining snags in clusters, as well as the live trees between the snags, keeps workers away from snags and provides canopy cover for wildlife using the snags.

Two studies on woodpecker use of snag clusters reported different results. No difference was found between woodpecker use of snag clusters versus scattered snags in western Oregon (Chambers 1997). In areas where stand-replacement fires had burned in ponderosa pine/Douglas-fir stands in Idaho, Saab and Dudley ( 1997) found that cavity nesters as a group select clusters of snags for nest sites instead of evenly spaced trees.

Most studies recommend managing snags in every 5- to 25-acre patch (Bate 1995, Evans and Martens 1995).

Because woodpeckers are territorial, only one pair of each species occupies the same territory; therefore, to attain the maximum density of cavity nesters, snags need to be distributed across the landscape.

In addition, retaining snags on all aspects and on all positions of the slope ensures habitat availability for wildlife species with different preferences. For example, pileated woodpeckers tend to roost in draws during summer but roost higher on slopes in winter (Bull and others 1992). Martens rest or travel in riparian areas a third of the time in summer but only half that often in winter; upper slopes ate used half the time in winter but only a third of the time in summer (Bull 1995).

Retaining snags close to living trees provides cover for cavity users. If snags are retained in the middle of a clearcut, species like northern flickers, Lewis' woodpeckers, bluebirds, and American kestrels (Falco sparverius) will use them for nesting, but most other woodpeckers will not nest in open areas.

In many areas, fuel-wood cutters are likely to remove snags along roads. This potential problem can be remedied by not leaving snags in areas that are accessible to fuel-wood cutters or by not counting snags left adjacent to accessible roads toward the number retained for a particular stand.

In summary, wherever the objective is to provide viable populations of primary and secondary cavity nesters, prudent managers will provide large-diameter snags when available, snags in a variety of structural classes, snags in every 5- to 25acre stand and in clusters if available, and snags on all slope aspects and positions of the slope, and adjacent to green trees.

Snag densities-Limited information is available on numbers of snags to retain for wildlife species in the interior Columbia River basin (Bate 1995, Bull and Holthausen 1993, Dixon 1995, Evans and Martens 1995) (table 1). The guide most widely used in the past, Thomas and others (1979), prescribed the number of nest and roost trees to leave for specified woodpecker populations, but the number was based on a hypothetical, untested model and did not include any snags for foraging. Three studies (Bate 1995, Bull and
Holthausen 1993, Dixon 1995) conducted in eastern Oregon have shown that retaining foraging structure is essential, in addition to nest and roost trees in managed landscapes. The Thomas model provided only two roost trees per pair per year, yet research has shown that individual pairs of pileated woodpeckers and white-headed woodpeckers use considerably more than two per year (Bull and others 1992, Dixon 1995). Radio-telemetry studies have shown that home range sizes of pileated woodpeckers (Bull and Holthausen 1993), white-headed woodpeckers (Dixon 1995), and three-toed and black-backed woodpeckers (Goggans and others 1988) are considerably larger than those used in the Thomas model. Raphael and White (1984) found that the relation between numbers of snags and cavity nesters is not linear, which was assumed in the Thomas model. The substitution factor used in the Thomas model is variable and largely a function of snag density. Neitro and others (1985) thought allowing substitution of snags that reduced the number retained was not appropriate. The Thomas model did not take into account the habitat needs of some of the secondary cavity nesters, like bats and brown creepers, that use such snag features as loose bark. In addition, Bull and Holthausen (1993) found lower densities of pileated woodpeckers in nine study areas than predicted by Thomas and others (1979) based on the number of snags present. The above studies present new data suggesting that some of the assumptions and data used in the Thomas model are not valid, and that the prescribed snag densities need to be revised upward.

We know of only three studies in the interior Columbia River basin that have calculated both the density of snags and woodpeckers in managed and unmanaged landscapes. Bate (1995) used six study areas in ponderosa pine stands and found woodpecker abundance was best predicted by hard snag density, large green tree density, canopy height, and number of canopy layers. Of the nine study areas, only one represented a relatively unmanaged forest with the number of snags that probably approximated historical ones. In this stand, Bate found 3.8 snags greater than 10 inches d.b.h., and 60 percent were larger than 20 inches d.b.h. These snag numbers supported 32.3 woodpeckers per 247 acres and represented the study area that most likely supported viable populations of cavity nesters. Dixon (1995) found similar results in some of the same study areas Bate used.

Another study relating woodpecker density to snag density was conducted in northeastern Oregon (Bull and Holthausen 1993). The two study areas that contained viable populations of pileated woodpeckers had an average of 4.2 and 3.8 snags (10 inches or larger d.b.h.) per acre and 0.5 and 0.4 nesting pairs per 247 acres, respectively. The two study areas were in lightly managed landscapes predominated by mixed-coniferous stands with a high density of logs.

Evans and Martens (1995) recommended densities of snags for retention on the Payette National Forest based on their ecological value, encompassing soil health, seedling regeneration, moisture retention, nutrient recycling, and wildlife use (table 1). The numbers that they recommended were derived from actual snag numbers identified during 
timber inventory and vegetation plots but were scaled down to the lower ranges of the snag numbers for the recommendations and include snags 10 inches d.b.h. and larger.

Ideally, data would be available on the exact number of snags required to support specific populations of primary and secondary cavity nesters. Unfortunately, this kind of information is not available. We do know, however, that the snag numbers presented by Thomas and others ( 1979) are not adequate to support the populations intended because of a lack of foraging strata and invalid assumptions used in the model. If management agencies have an objective to manage for viable populations of woodpeckers, providing numbers of snags that have been shown to support viable populations in the recent studies would be prudent.

Although snags are the key structure typically focused on for cavity nesters, realizing the importance of the forest surrounding the snags also is essential. Some species like the pileated and white-headed woodpeckers and American martens are associated with older forests. For white-headed woodpeckers, the snags must be in association with large-diameter ponderosa pines. For pileated woodpeckers and martens, logs, largediameter green trees, and a dense canopy are needed. Leaving large-diameter snags or green trees in younger forests, also has value as providing biological legacies.

Snag retention in burns-The above management implications apply to healthy green stands. With vast areas of Oregon, Washington, and Idaho burned by wildfires in the 1990s, there is much interest in determining numbers of snags to retain in burned areas after harvesting. Saab and Dudley (1997) reported that woodpeckers selected nest sites with snag densities greater than those measured at random sites in ponderosa pine/Douglasfir forests with stand-replacing fires. From 10 to 14 snags per acre were retained in burned stands that were harvested; about 38 to 42 snags per acre were in the unharvested burned stands. Seven species of cavity nesters using the burned stands selected nest sites with more than 20 snags per acre, where snags were distributed in clumps. Lewis' and white-headed woodpeckers, and American kestrels selected the largest, most heavily decayed snags available for nesting. Evans and Martens (1995) presented recommendations for numbers of snags to leave in burned stands.

Green tree replacements-Snags are a dynamic resource; old snags fall and living trees die to become new snags. Snag-dependent wildlife need a continuous supply of snags over time. To provide a continuum of snag habitat, future snags must be planned for by leaving green trees to eventually become snags in managed stands. To determine the number of green tree replacements, information on fall rate of standing snags, snag density, live stem density, and mortality rate of live stems is required. Various models have been developed to calculate the number of green trees to provide for recruitment when specific stand inventory information is available (Bull and others 1980, Cimon 1983, Schommer and others 1993). If snags are to be created by killing green trees when the stand becomes snag deficient, the number of green trees required is less because the manager does not have to rely on natural mortality to replace those snags that fall. Creating snags is costly, however, and stands are seldom monitored to determine when trees need to be killed.

\section{Snag Longevity}

Snag longevity, or the amount of time a snag stands, is essential information for managing the snag resource. The length of time snags stand is a primary factor in determining the number of green tree replacements needed to maintain a specific snag density over time. Snag longevity is a function of many factors including species, diameter and height, percentage of heartwood, cause of death, soil type and moisture, forest type, and prevalence of windstorms. Because so many factors influence how long a snag stands, fall rates should be determined by species and size class on each management area. Listed below are studies that report snag fall rates. When possible, the amount of time when 50 percent of snags in a particular study have fallen will be reported.

Several studies have reported fall rates of beetle-killed ponderosa pine. Keen (1955) reported that 50 percent of the ponderosa pines in southern Oregon and northeastern California fell 9 to 10 years after death on pumice soils and 6 to 7 years after death on loam soils. The percentages of snags that fell after 7 years by diameter class, are presented in the following tabulation:

\begin{tabular}{|c|c|c|}
\hline Diameter & class (inches) & Percentage \\
\hline $10-18$ & & 75 \\
\hline $20-28$ & & 65 \\
\hline $30-38$ & & 50 \\
\hline $40-48$ & & 35 \\
\hline$>50$ & & 30 \\
\hline
\end{tabular}

Most of the beetle-killed ponderosa pines in Colorado fall between 7 and 10 years after infestation (Schmid and others 1985). Trees were 7 to 22 inches d.b.h.

In northeastern Oregon, half the ponderosa pines less than 10 inches d.b.h. fell 7 to 8 years after death and half those 10 to 19 inches d.b.h. fell after 8 to 9 years (Bull 1983). Beetle-killed lodgepole pines have similar fall rates, with half of those less than 10 inches d.b.h. falling within 6 to 7 years and half of those 10 inches and larger falling after 7 to 8 years (Bull 1983). In a second study in northeastern Oregon (Bull and Partridge 1986), half of the ponderosa pine snags less than 20 inches d.b.h. fell after 6 years; half of the ponderosa pine snags 20 inches and larger fell after 9 years.

Beetle-killed spruce in Colorado stood much longer than ponderosa pines reported in the studies above. Mielke (1950) found that 84 percent of beetle-killed spruce remain standing after 25 years. Hinds and others (1965) found that 72 percent of beetle-killed spruce remain standing after 20 years.

Fire-killed snags may or may not stand longer than beetle-killed snags, depending on the area. Dahms (1949) reported that a little over half the ponderosa pine snags are down 10 years after a fire in central Oregon. In Montana, nearly half of all lodgepole pine snags fall by the fifth season (Lyon 1977). In California, Kimmey (1955) described the 
breakup of a fire-killed stand, although specific fall rates were not presented. In the fourth and fifth year after the fire, many ponderosa and Jeffrey pine (Pinus jeffreyi) broke off at the ground or up to 50 feet above the ground. By the fifth year, the general breakup continued until only scattered barkless snags and stubs remain.

In northeastern Oregon, different methods of killing ponderosa pines were investigated (Bull 1996c, Bull and Partridge 1986). Trees that had been topped stand the longest; half of those less than 20 inches d.b.h. are down after 10 to 12 years; half of those 20 inches or larger are down after 12 to 17 years. Half the trees injected with a silvicide are down 7 years after treatment. Half the girdled trees are down 9 years after treatment.

Fall rates of snags that have been created differ. Ponderosa pines infected with dwarf mistletoe were frilled and poisoned with an herbicide in the Southwest; after 10 years, 95 percent of those trees are down (Fairweather 1995).

All of these studies suggest that most ponderosa pine and lodgepole pine that died from fire or beetles in the interior Columbia River basin have fall rates of less than 10 years. Small-diameter snags fall sooner than do larger ones.

\section{Sampling Techniques}

Knowledge of snag density is essential for managing forest stands effectively, as well as for complying with standards and guidelines. Various methods have been used to determine snag densities: area-wide counts, fixed-radius circular plots, variable-radius plots using prisms (Bull and others 1990), and variable-strip transects (Bate and others, in press). Total counts of snags over large areas are very timeconsuming but yield the most accurate density information. Fixed-radius plots typically need to be at least 1 acre because snags are usually scarce and variance is high. Many plots are usually required to accurately estimate snag density.

Bate and others (in preparation) have developed a more efficient method of sampling snags than either area-wide counts or fixed-radius plots: data are collected from a pilot sample transect and used in a computer program. The program determines the optimal length and width of a strip transect within a given area; the optimal size is that which minimizes the cost and variance. The program then provides the necessary sample size to obtain a snag density within the desired statistical bounds. Transect lengths are either 164 or 328 feet; transect widths range from 33 to 131 feet. The

Table I-Density of snags reported or recommended in four areas; numbers are snags per acre larger than 10 inches d.b.h. (unless otherwise stated), and the percentages represent snags larger than 20 inches d.b.h.

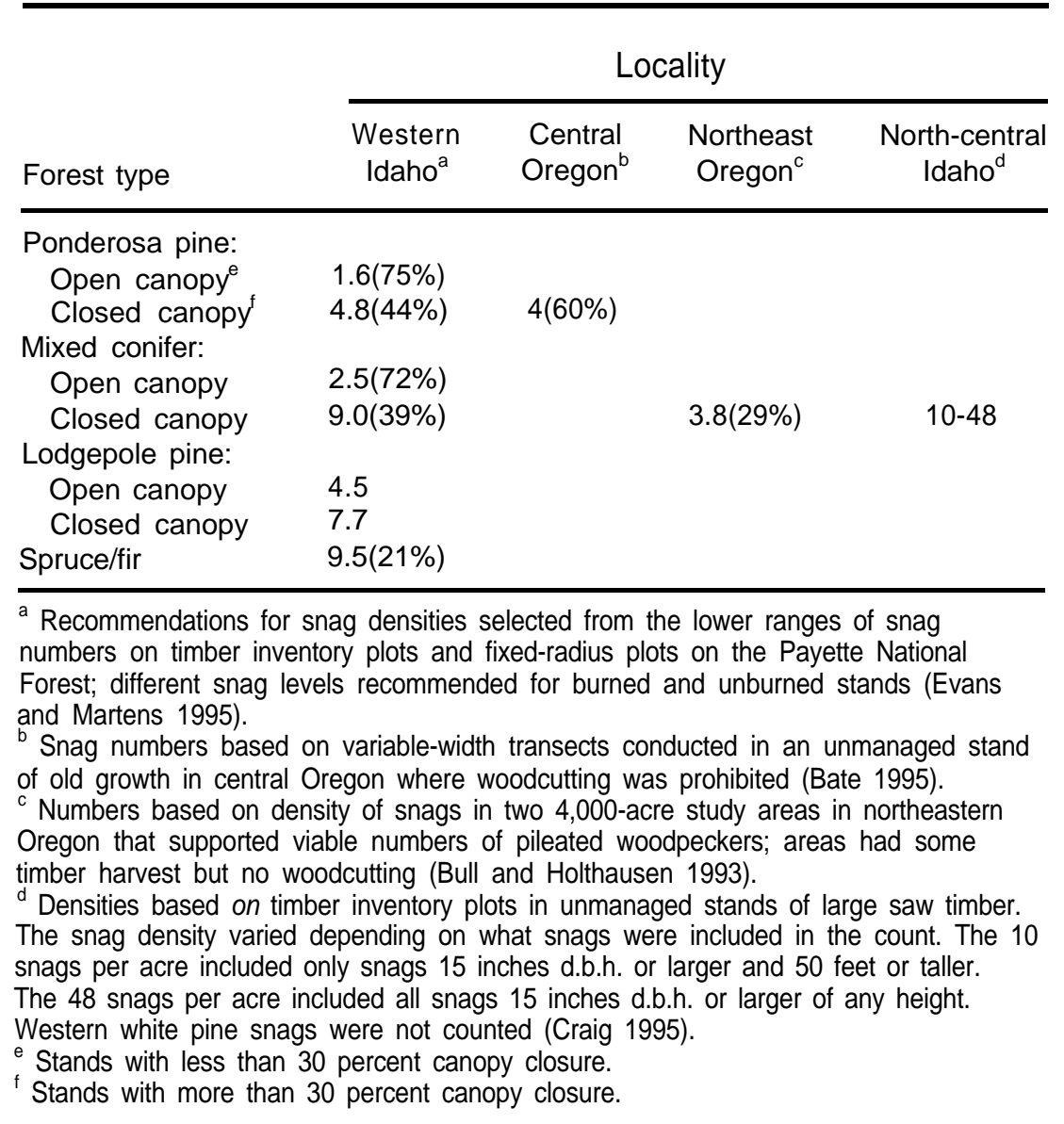


program also provides a "distribution index," which is an estimate of the percentage of the sampled landscape supporting target snags or trees.

\section{Creating Wildlife Trees}

In managed stands, retaining existing snags is the most ecologically sound and economical approach to providing wildlife trees. If stands are devoid of snags, however, an option is to alter or kill living trees. Depending on the method used, killing trees can be costly and may not produce the desired decay conditions. Years may pass before the decay is sufficiently advanced to promote cavity-nester excavations.

Bull and Partridge (1986) investigated six methods of killing ponderosa pine. They determined that topping trees with either a chainsaw or explosives produced snags that stood the longest and received the greatest nest use by woodpeckers (figs. 48 and 49). In this study, girdling, fungal inoculation, and beetles attracted by pheromones did not consistently kill the tree. Trees killed by girdling or silvicides fell over too quickly to provide wildlife nest trees.

In a study in New Mexico, all of the ponderosa pines killed by girdling were used for foraging by woodpeckers. Most of the trees greater than 16 inches d.b.h. were standing after 7 years, and about 30 percent contained woodpecker nest sites (Parks 1996b). Because the climate in the New Mexico sites is drier than in the Oregon study area used by Bull and Partridge (1986), basal decay of killed trees may have been less, so the trees stood longer.

Recent work by Parks and others (1996a, 1996b) documents a new method of inoculating live trees with decay fungi. Six years after inoculation of 60 living western larch, 14 percent contained woodpecker cavities near the point of inoculation. These trees may remain alive for decades with a pocket of decay that woodpeckers can use for nesting. Trees may be logged next to these trees without safety concerns, and live trees are less likely than dead trees to be lost to fuel-wood cutters. These preliminary results for western larch suggest that inoculation produces desirable wildlife trees at a lesser cost than killing trees to create snags.

A variety of wildlife tree structures can be created with a chainsaw in standing, living trees. Trees can be topped leaving a horizontal branch structure on which ospreys (Pandion haliaetus) can build nests (fig. 50). A depression can be cut into the top of a tree that has been topped to produce a nest site for great gray owls (fig. 51). Artificial cavities and hollows can be cut into standing and downed trees (figs. 52, 53, and 54). Slits can be cut into trees to create roosting habitat for bats (fig. 55). These techniques and others are described by Brown (1996).

Three primary considerations in creating wildlife trees are the target wildlife species for which the structure is being created; the tree species, size of tree, and habitat locality most likely to be used by the targeted wildlife species; and the method of altering or killing trees that is most likely to produce long-standing trees in a given geographic area. Rainfall, snowfall, incidence of windstorms, and prevalent decay organisms all must be considered.
Thousands of trees have been killed to create snags in the interior Columbia River basin in the last 15 years. Few of them have been monitored, however, to determine whether long-lasting, quality snags were actually produced. Because climate and decay organisms differ with area, results of management activities, such as snag creation, must be monitored to ensure that results warrant the cost of these treatments. We include a data form to monitor wildlife use of created snags in appendix A.

\section{Review}

- Ponderosa pine, western larch, quaking aspen, and paper birch are favored tree species for nest sites of woodpeckers in many areas in the interior Columbia River basin.

- Large-diameter snags provide nest habitat for the greatest variety of cavity nesters and stand longer than smaller snags.

- Snags can be classed into three structural classes that are a simplified version of past decay class categories.

- Snags should be provided in every 5- to 25-acre stand, in clusters if available, on all slope aspects and positions of the slope, and adjacent to green trees.

- Recent studies have shown that the snag model developed by Thomas and others (1979) did not accurately predict woodpecker abundance based on snag abundance. New information suggests that foraging strata (snags and other structures) must be incorporated into any snag model, and that snag numbers need to be revised upward.

- Published data suggest that populations of cavity nesters were viable in stands of ponderosa pine and mixed-conifer forests that contained about four snags per acre, a large component of old-growth stands, and abundant logs.

- Snags can be retained over time by using models for green tree replacements.

- Snag longevity depends on cause of death, tree species, diameter, height, amount of heartwood, geographic area, and site conditions.

- Creating snags and other wildlife structures can mitigate the loss of natural habitat, but retaining existing structures is most cost effective and ecologically sound.

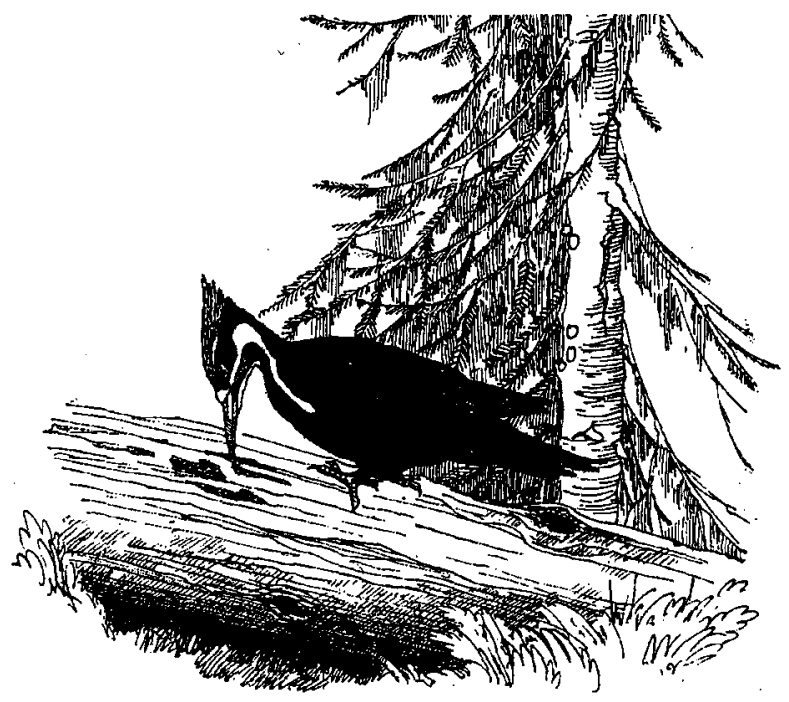




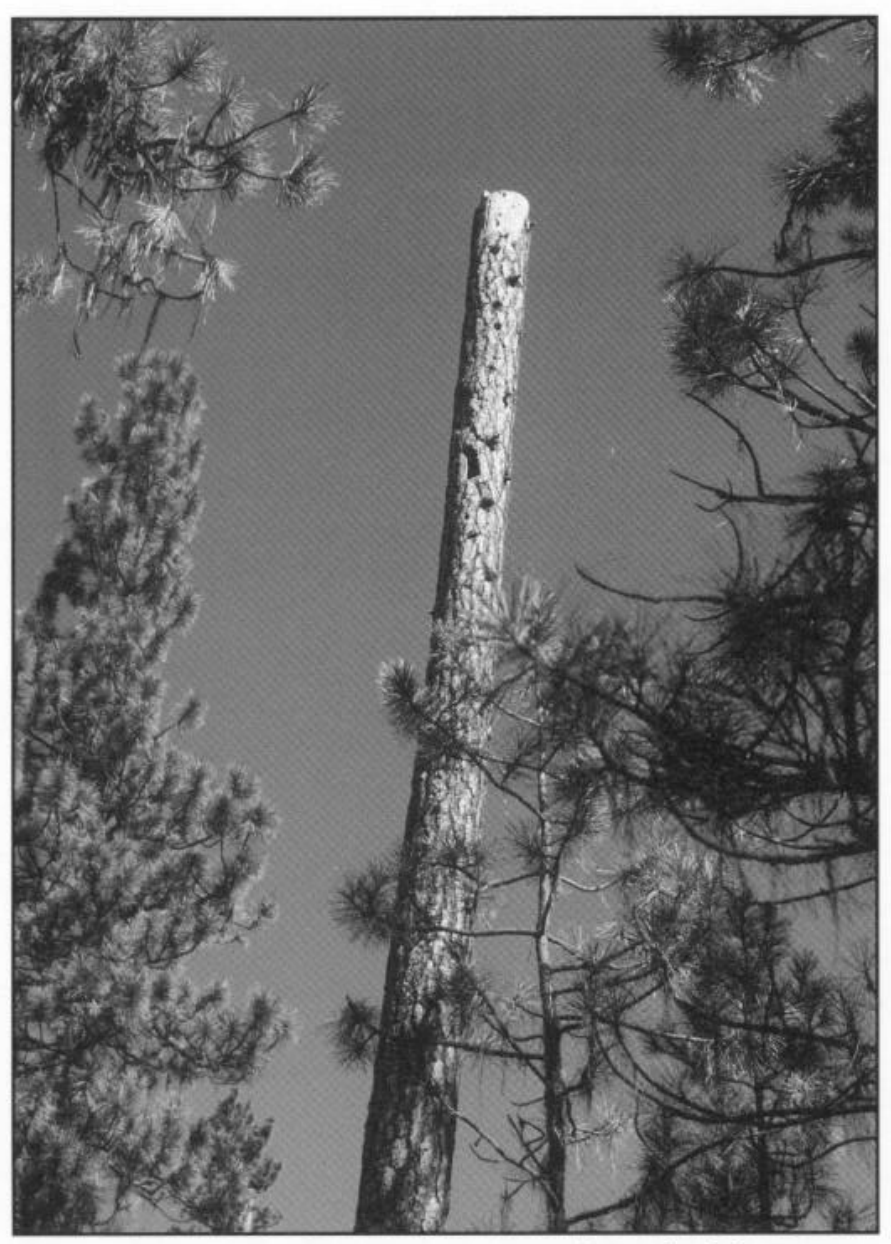

Figure $48-$ Ponderosa pine snags created by topping received the greatest amount of woodpecker nest use in eastern Oregon.

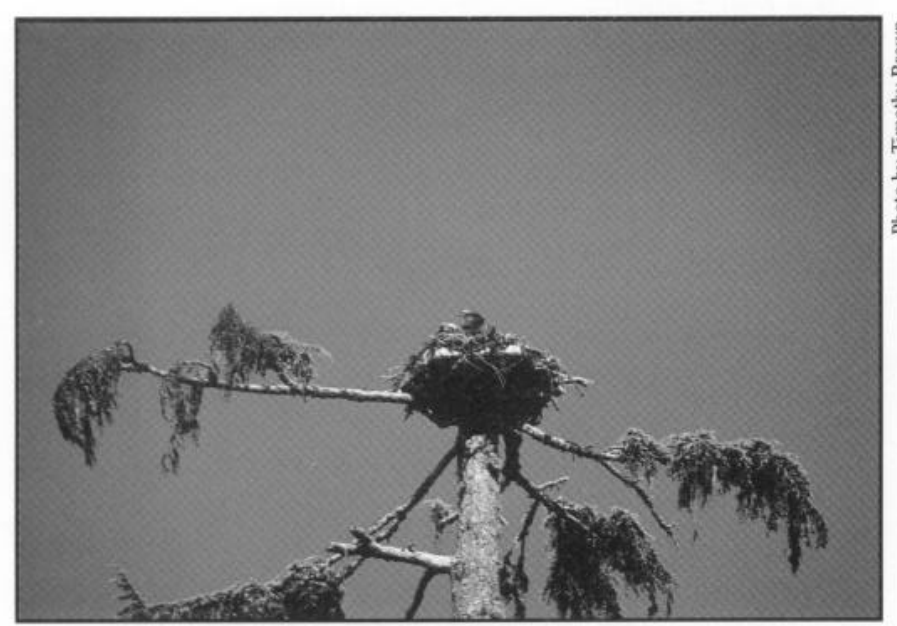

Figure 50-Topped trees with a platform provide nest sites for ospreys.

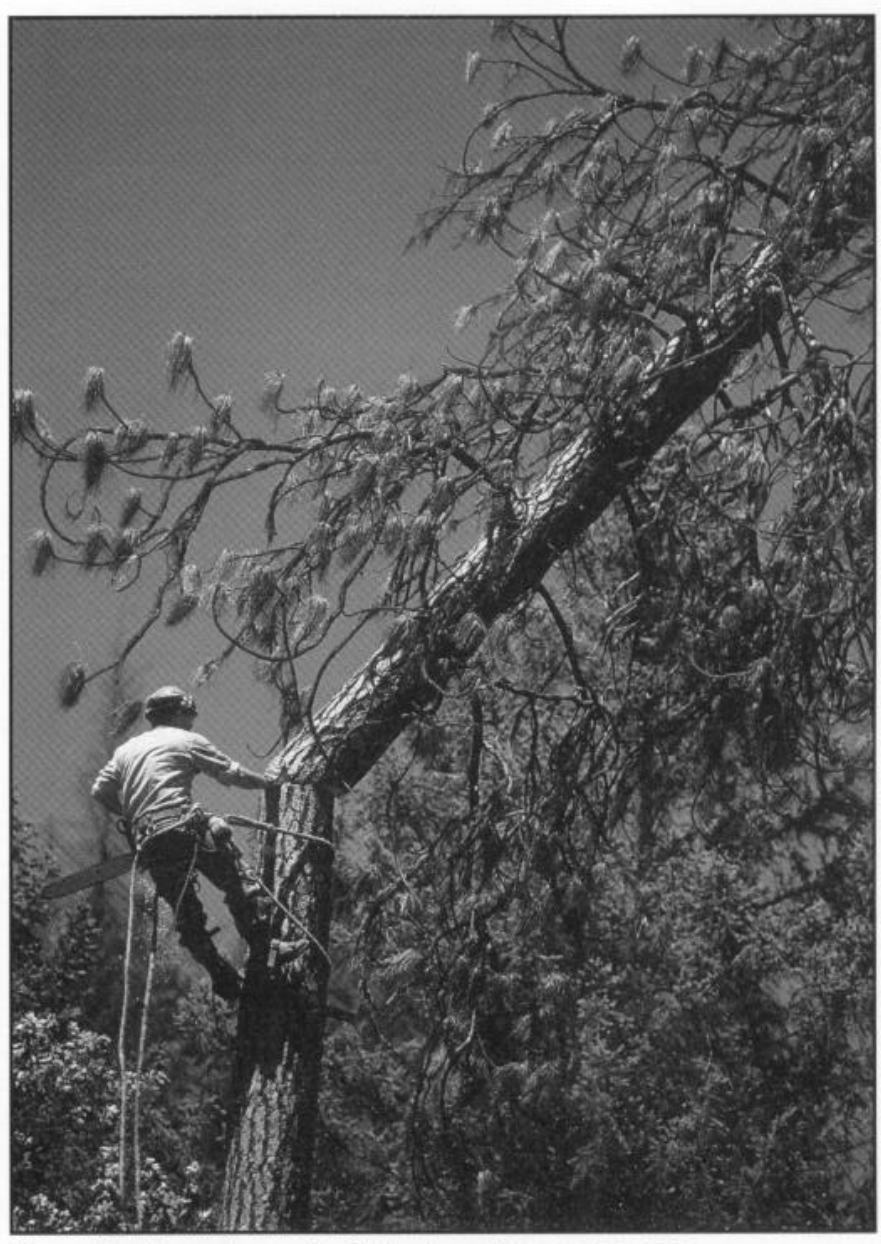

Figure 49-A ponderosa pine being topped to create a snag.

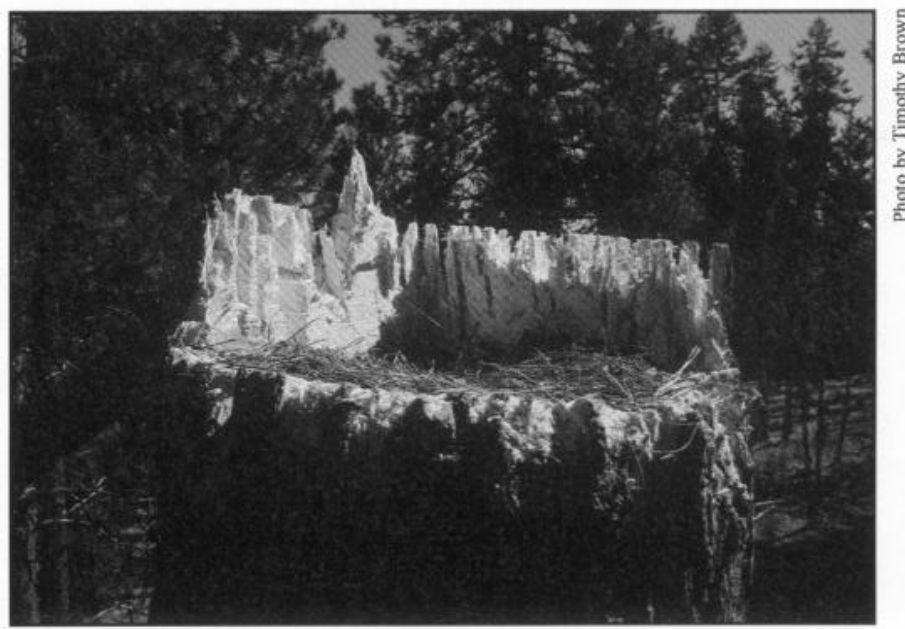

Figure 51-This nest site for great gray owls was created by topping a tree and cutting a depression in the top of it. 


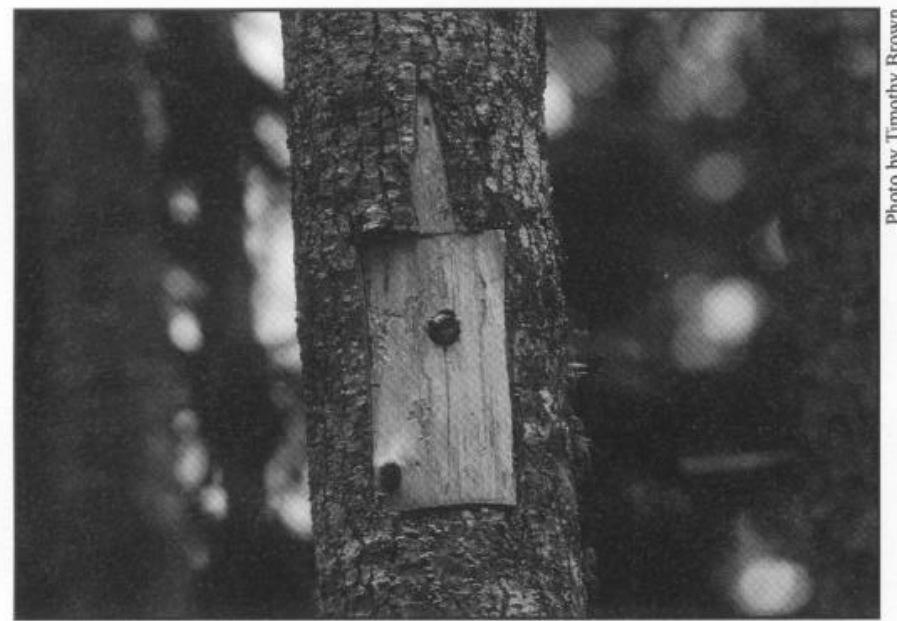

Figure 52-This artificial cavity was made by removing a block of wood and fashioning a face piece with an entrance hole.

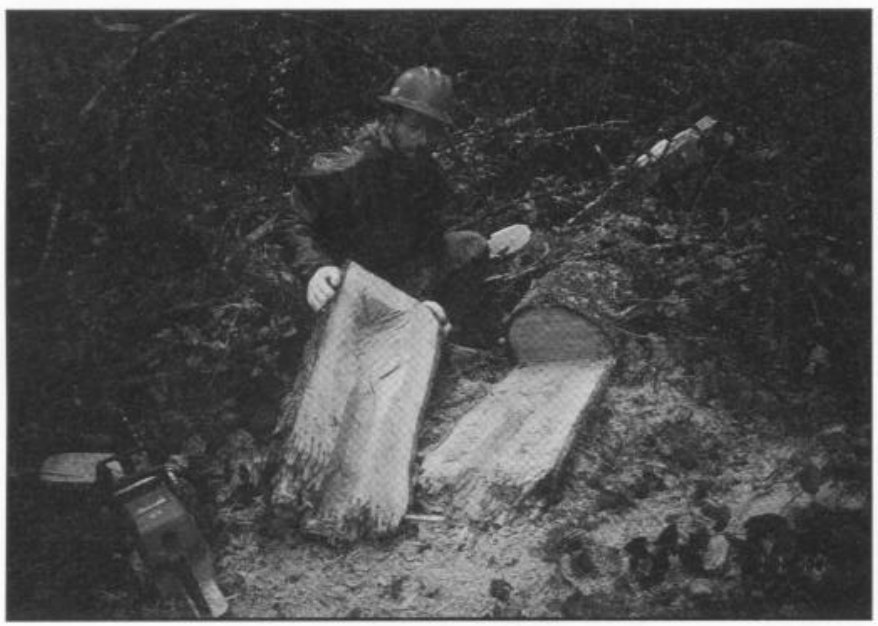

Figure 54 Chainsaws can be used to create hollow chambers in logs.

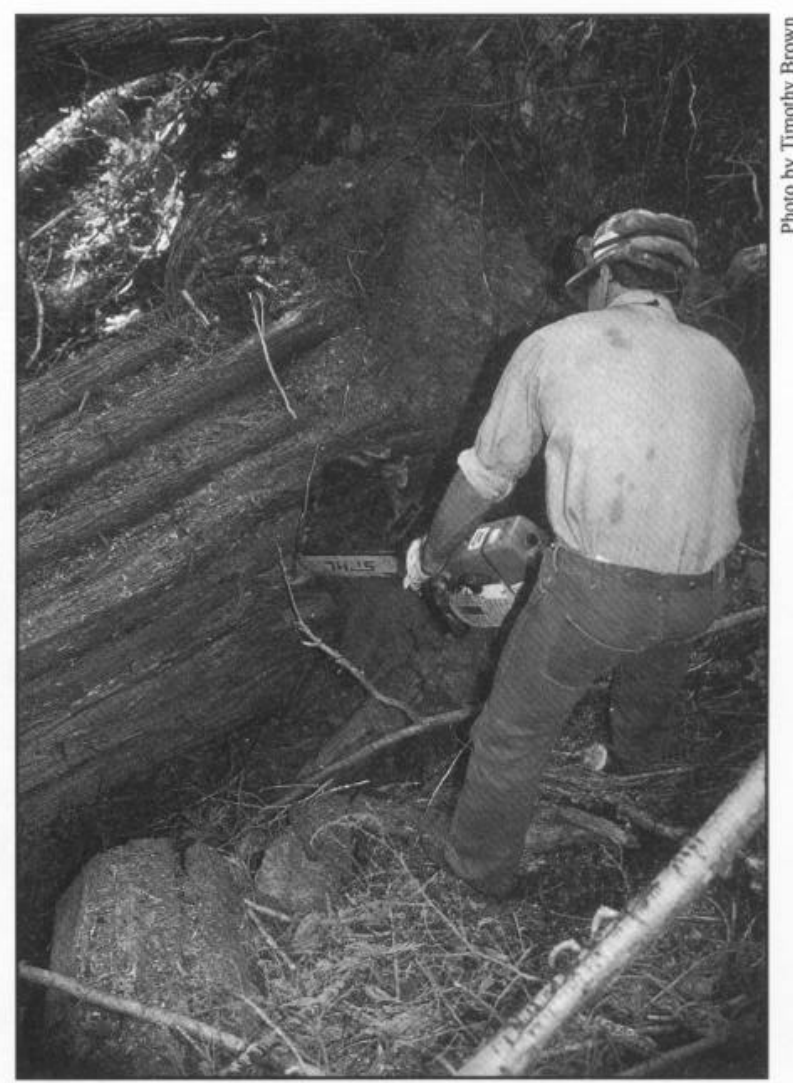

Figure 53 Cutting a hole into a hollow western redcedar log allows access by wildlife.

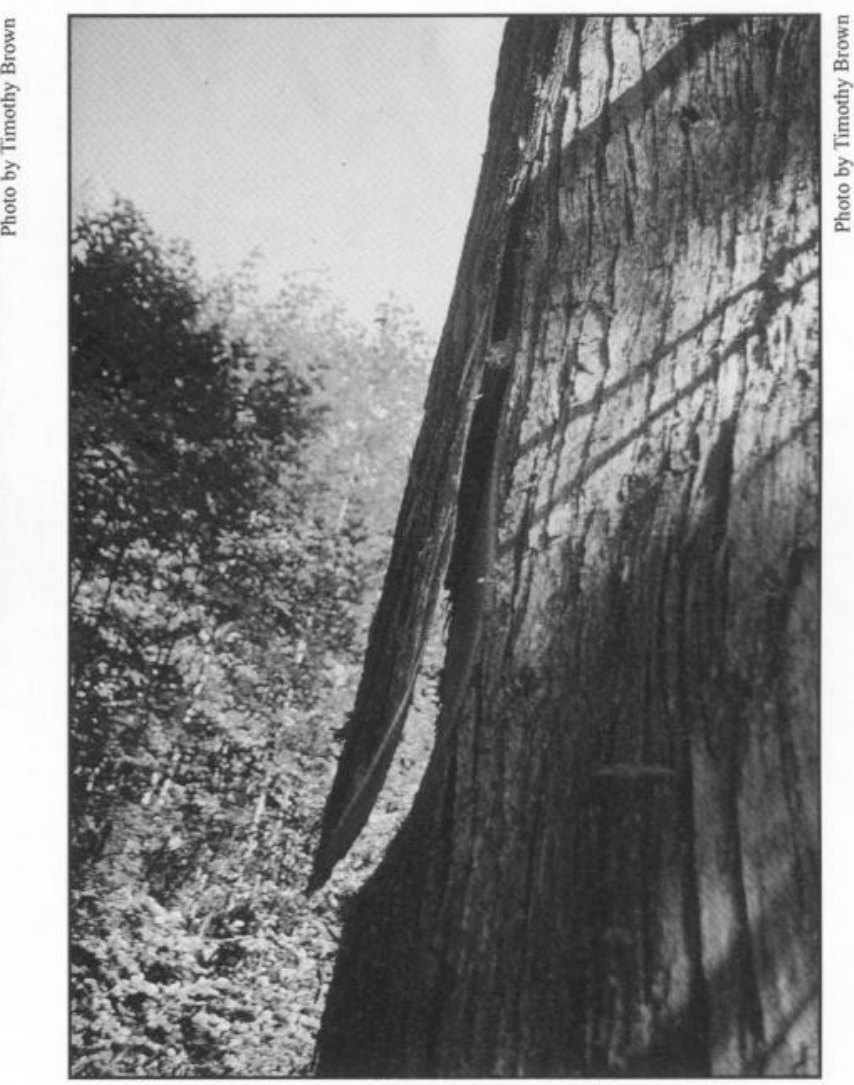

Figure 55 - Slits cut into trees provide roost sites for bats. 


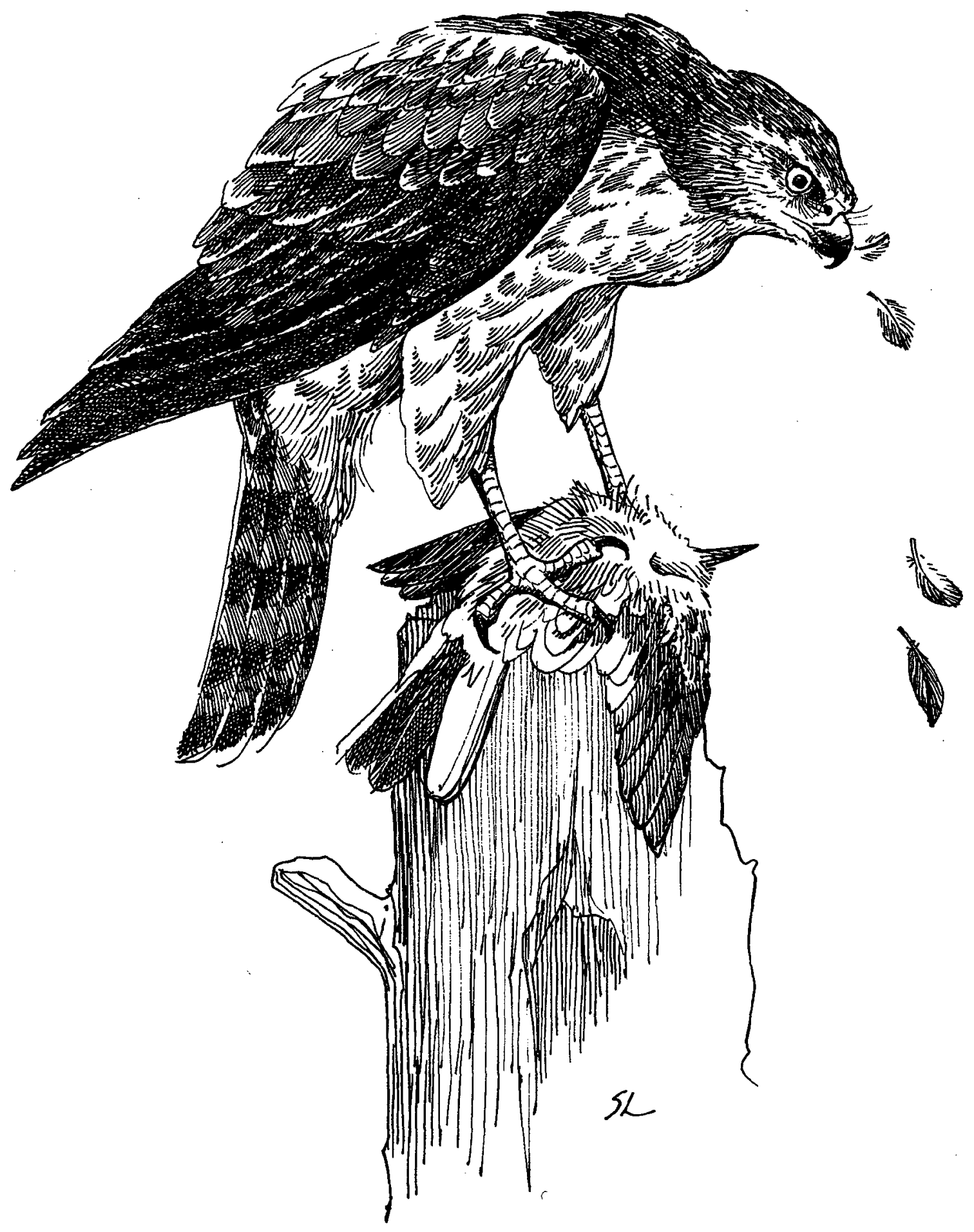




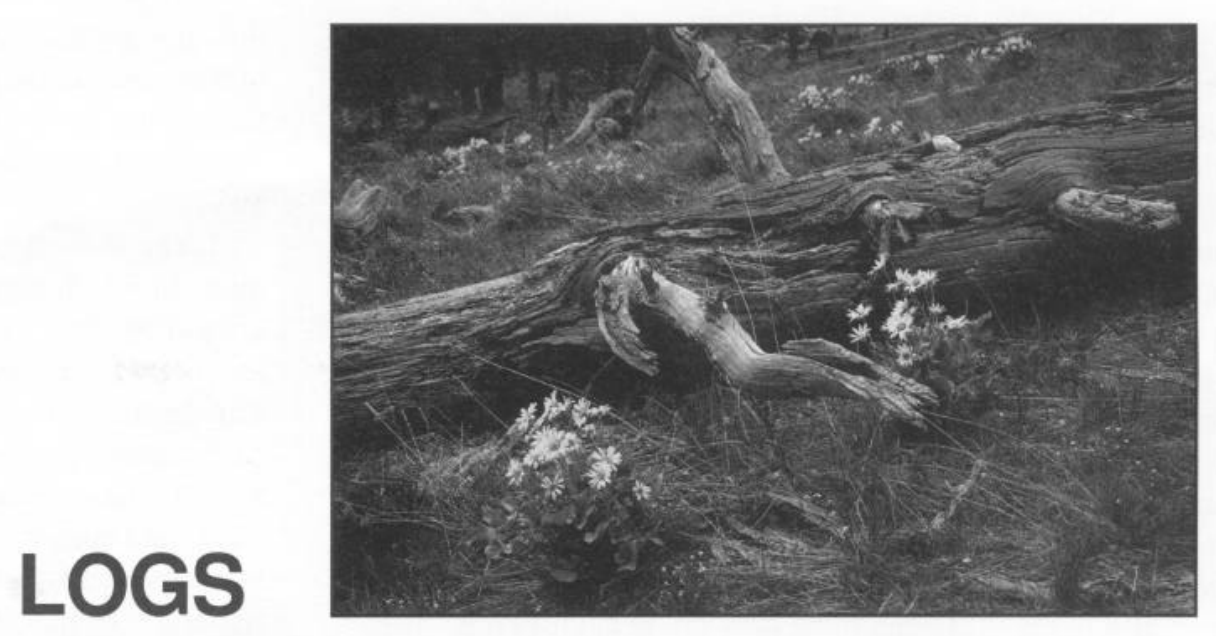

\section{Ecological Processes and Functions}

The natural fate of all living trees is to become part of the down-wood component on the forest floor. Characteristics of the living and dead standing component in a stand determine the species and physical attributes of the material that falls to the ground. Late-successional stands typically have largediameter logs on the forest floor recruited from the wood resources in the standing trees through a variety of natural processes such as breakage; falling trees; and transport caused by snow-loading, windstorms, avalanches, debris flows, fires, and floods. Other natural processes such as the activity of insects and diseases that kill or physically weaken trees likewise contribute dead wood to the forest floor. All these factors can directly or indirectly result in death and falling of individual branches, tops, or whole trees. Stands or patches of trees and landscape-scale tree mortality are common events in the history of forest ecosystems. All of these mortality and decay processes are natural and necessary; they contribute to the nutrient reserves and physical and chemical characteristics of soils in healthy forests. Thus, dead wood in all its forms is a fundamental feature of healthy forests.

The "life" or persistence through time of dead trees, especially large ones, can last several decades. Over a period of possibly a century, logs serve as a source of organic and inorganic nutrients and chemical components in soil development. The constituents contributed by logs enrich the soil and improve its structural properties, allowing plant growth. Logs contribute to the water economy of a site and provide microhabitats that protect wood-dwelling organisms with moist, thermally stable, predator-protected niches in which to live. Logs in or near streams, ponds, or lakes provide structure for amphibians, beaver, mink, otter, and birds (Lofroth, in press; Maser and Trappe 1984).

Organisms representing a broad array of plants, invertebrates, and vertebrates use log habitats in forests. From microscopic protozoa and fungi to wildlife and roots of large trees, down wood teems with life. Many of these organisms are connected by functional pathways that are partially or completely unknown. For both simple and complex plants and animals, down wood in all its forms represents a rich substrate on which they feed and live.

We use the term "logs" for down woody material such as trees, branches, or tops that have fallen to the forest floor. The minimum piece-size to qualify as a log has a large-end diameter of 6 or more inches and a length of 8 or more feet. A leaning snag that forms less than a $45^{\circ}$ angle with the ground is considered a log. Most logs touch the forest floor, but sometimes they fall like jackstraws and are supported above ground by other logs (fig. 56).

Logs can be considered as either places animals forage or places that afford them protection. Insect-eating, funguseating, wood-eating, and predaceous animals find rich and varied sources of food in and associated with logs. Besides hiding cover and protection, logs provide physically complex structures where animals find stable temperatures and moisture for nesting, denning, feeding, and food storage. Logs also serve as places for sunning and as lookout posts. Spruce grouse (Dendragapus canadensis) regularly sit on logs sites where they are apparently better able to avoid predation. In spring, males use these elevated sites as walkways for their displays (Harrison 1996).

Small mammals use logs extensively as runways. This association between log structure and small mammals was apparent in studies of radio-tagged great gray owls. Nearly 80 percent of the time, down wood was within 3 feet of where great gray owls captured or attempted to capture prey (fig. 57) (Bull and Henjum 1990). Maser and others (1979) described wildlife uses of logs in relation to log decomposition class, size, age, log species, and distribution. They described processes that lead to increased and more varied uses of logs by wildlife, plants, and invertebrates as logs decompose. Lofroth (in press) reviewed literature that further describes wildlife uses of logs, including log habitats under snow.

The size, distribution, and orientation of logs are more important to wildlife than are the tonnage or volume, as used in characterizing woody fuels (Maxwell and Ward 1980). In general, specific wildlife uses are correlated with log size. 
The smaller logs benefit small mammals, amphibians, and reptiles, for which they function primarily as escape cover and shelter when the animal can get inside or under the log (fig. 58). Large-diameter logs, especially hollow ones, also benefit a variety of other vertebrates like martens, minks, coyotes, bobcats, cougars, and black bears (Lofroth 1993; Lofroth, in press; Maser and Trappe 1984) (fig. 59). Hollow logs are used by black bears for winter dens in some parts of their range. During late summer and fall, bears forage for invertebrates in logs (fig. 60). What percentage of their diet depends on this resource is not known, although it seems to be substantial based on current studies in northeastern Oregon (Henjum and Akenson 1996). Research on fishers (Martes pennanti) suggests that up to three dens may be used in rearing a litter. Although most dens are in cavities high in large (36-inch d.b.h.) living or dead trees, large logs also are used. In California and Montana study sites, one den was in a 36-foot log that was large enough to provide a convoluted 12inch diameter cavity through its length; another den was in a 59-inch log of white fir (Abies concolor) (Powell and Zielinski 1994).

Lynx (Lynx canadensis) select dense, mature forested habitats that contain large logs and upturned stumps to provide security and thermal cover for kittens. In northcentral Washington, lynx den in Engehnann spruce/subalpine fir/lodgepole pine stands with high densities of downed trees supported 12 to 48 inches above the ground, which provide structure and diversity for denning and hunting (Koehler and Aubry 1994).

Distribution of logs influences wildlife use. Trees sometimes die in clumps or patches from diseases, insect activity, or fire. Mortality of this kind ultimately results in aggregations of logs. Within relatively continuous forested stands, however, logs appear fairly regularly. In late- and oldstructure mixed-conifer stands in northeastern Oregon, we found that densities of logs fell within relatively close ranges; that is, standard errors were 8 to 18 percent of the means. These stands were not randomly selected stands, however, but were associated with pileated woodpecker home ranges (Bull and Holthausen 1993, Torgersen and Bull 1995).

Amounts and distribution of logs in managed landscapes have varied effects on wildlife and management strategies. Too many logs may impede travel by deer, elk, and cattle; they also may present increased fire hazard (fig. 56). Large numbers of logs afford excellent cover habitat for small vertebrates (fig. 56). Heavy accumulations of down woody debris can increase seed losses and damage to tree seedlings by squirrels, chipmunks, and mice, but these accumulations do not necessarily result in such damage. Research suggests that seedlings may actually be protected from grazing and scorching by the physical barrier and shading provided by down logs. Such protection often outweighs the negative effects of increased habitat for rodents and problems associated with them (Dimock 1974, Maser and others 1979). Orientation of logs can influence wildlife use. Logs that lie along the contours of a slope may be used more by wildlife than logs oriented across contours, especially on steep slopes.
Soil and organic debris that accumulate along the upslope side of a $\log$ encourage seedlings to establish and grow, which in turn attract invertebrates and small vertebrates that find more diverse structure and niches for activity (Maser and Trappe 1984).

Large numbers of down trees can form a maze of logs, many of which may be supported 2 or more feet above the ground by other logs. Patches of these jackstrawed logs often are found in late- or old-structured stands of lodgepole pine, Engelmann spruce, subalpine fir, and grand fir. Although such conditions may represent a significant fire hazard, they also provide critical structures for some animals. Marten, mink, and cougar hunt in them; when snow covers the logs, a complex array of snow-free spaces and runways provide important habitat for protection and foraging by martens, fishers, and small mammals under the snow. Tree squirrels also spend much of the winter in this environment, where they feed on seeds from cached cones.

Slash piles remaining after harvest can benefit some wildlife like rodents, hares, and rabbits (fig. 61). Increased commercial markets for chips and firewood have increased demand on this component of wildlife habitat. No completely researched guidelines exist for distributing logs and woody debris in managed stands. Although quantitative, spatial, and functional relations are still poorly understood, that does not make any single component or feature of distribution any less important (Bartels and others 1985, Maser and others 1979).

\section{Decay Process}

The decay of logs is continuous; some decay may begin even before a tree dies. The rate and patterns of decay and the decay organisms depend on many dynamic factors. Did the down log derive from a fallen snag or a living tree? If the $\log$ came from a snag, what killed the tree? How big is the $\log$ ? Is it a long, small-diameter log or a short, large-diameter log?

Every living tree is composed of tissues that perform specific functions and have different structures to accomplish these functions. These tissue-substrates continue to provide different environments in logs over many years for a host of microbes, higher plants, and invertebrates. The succession of decay-related organisms in turn produces a continuum of decayed wood with many different structural and textural characteristics.

Hollow logs are an example of a particularly important structural category. Logs do not become hollow on the ground; they are hollow because of the action of heart-rot fungi that occurred when the tree was alive. Such hollow trees ultimately die and fall to the forest floor (fig. 59).

The physical setting in which the log resides also affects the decay process. Slope, aspect, exposure to sunlight, elevation, and the degree to which the $\log$ is in contact with the ground all influence the characteristics of decay. Even orientation of the log can influence decay: logs that are oriented along the contours of a slope accumulate soil and debris against the uphill side, which holds moisture and hastens some decay processes. Charring of logs can hamper excavation by some invertebrates and vertebrates for many 


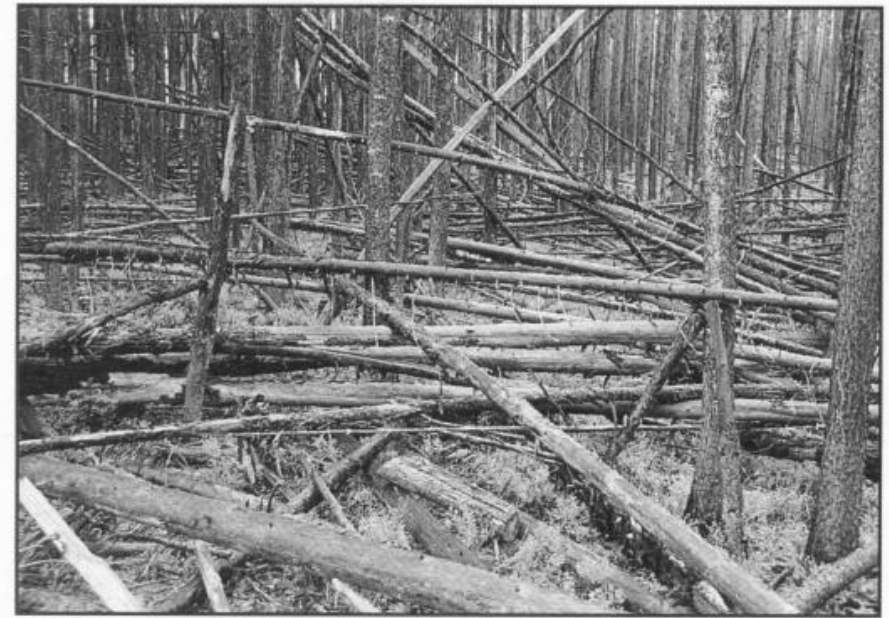

Figure 56-Accumulations of logs provide cover for small mammals but may impede movement by deer and elk.

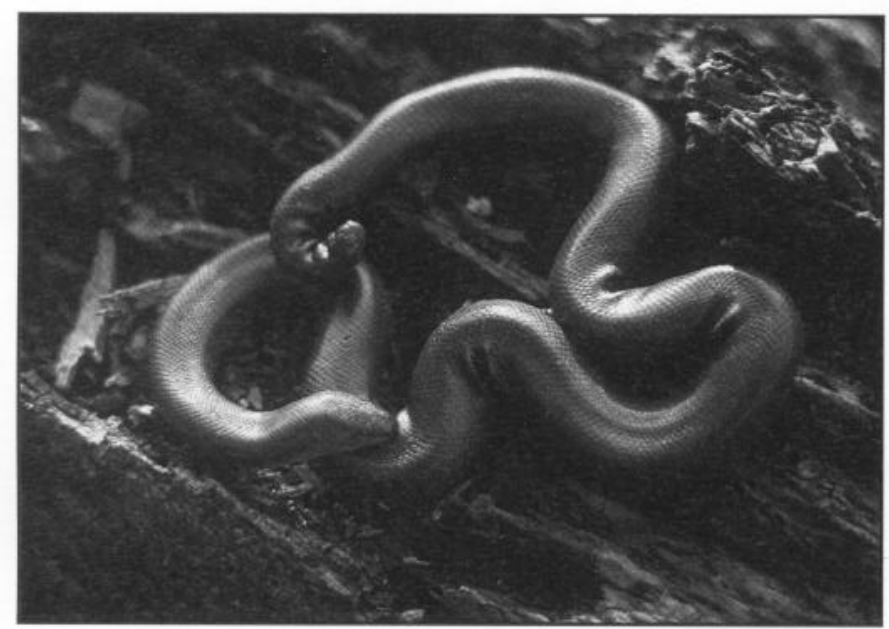

Figure 58 - Rubber boas (Charina bottae), other reptiles, and amphibians may burrow into decayed logs.

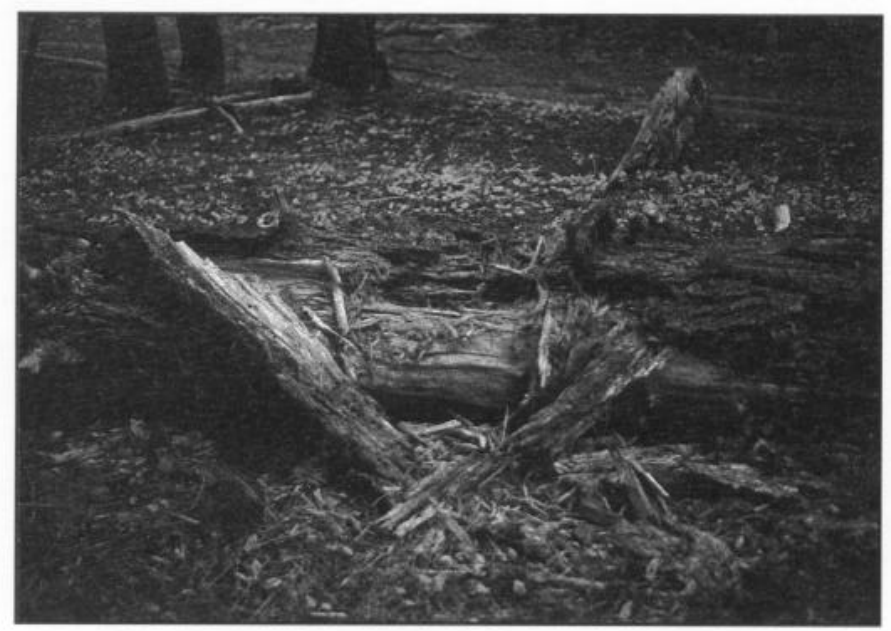

Figure $60-$ Black bears forage extensively on carpenter ants and beetle larvae in logs during late summer and fall.

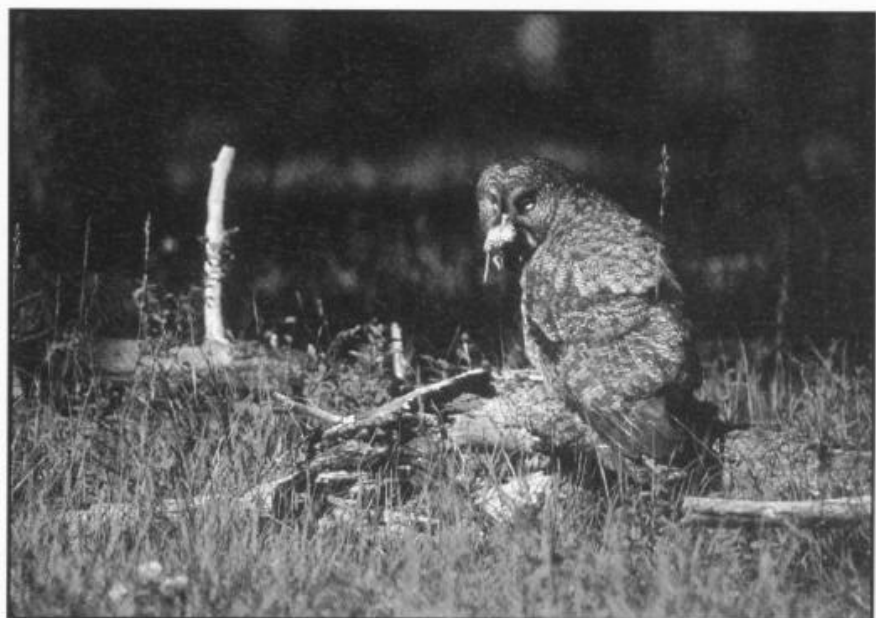

Figure 57 - Prey captured by great gray owls is often associated with down woody material.

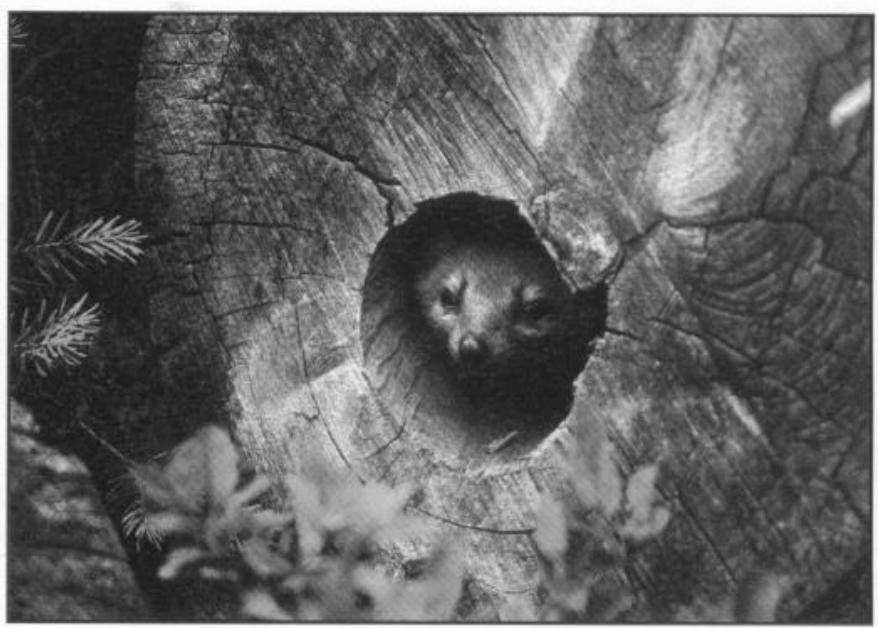

Figure 59-Hollow logs are used by martens, black bears, and smaller mammals for den sites and shelter.

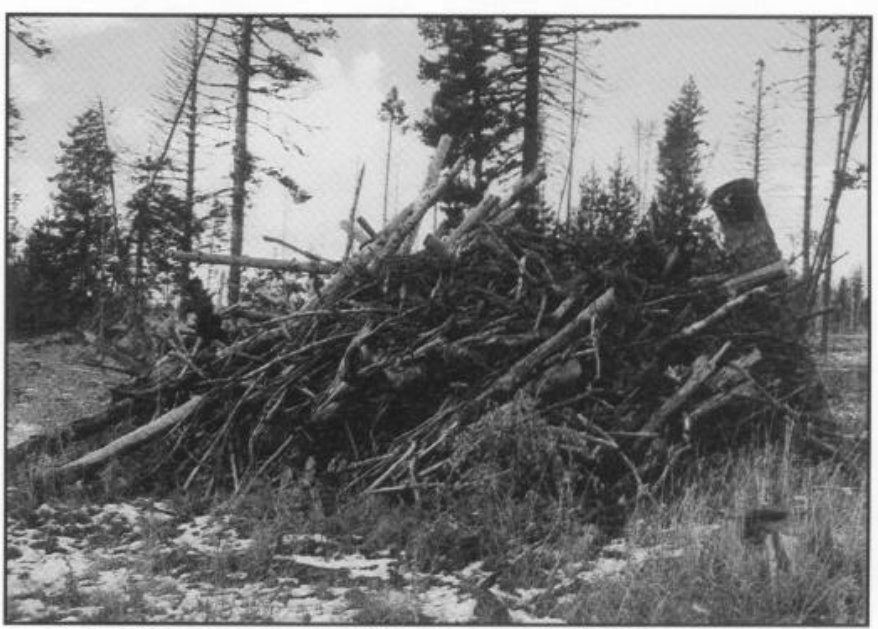

Figure $61-$ Slash piles provide cover for wildlife. 
years, thus diminishing their wildlife habitat values even if such logs are well distributed and of large size (Maser and others 1979). The works of Maser and Trappe (1984) and Lofroth (in press) are excellent sources for more information on the dead wood cycle and terrestrial and aquatic life processes in logs.

\section{The Log Resource}

Size, species, and-number of fogs-These factors may be the most basic ones in describing the log resource in terms of its use by wildlife. Little information exists on the significant descriptive features for log resources. Appendix B provides a sample data form for inventories of the down log resource. Even determining the species of a decayed down $\log$ can be challenging, especially when some or all of the branches, cones, and bark are missing. Parks and others (in press) have prepared a field guide as an aid to identifying species of snags and logs of the interior Columbia River basin.

Bull and Holthausen (1993) found that in 38 percent of their observations of foraging pileated woodpeckers, the birds used Douglas-fir and western larch logs in mixed-conifer stands. Moreover, these birds favored logs that were 15 inches or greater in large-end diameter and in advanced stages of decomposition. A companion study to determine log characteristics that influenced the ant prey of woodpeckers showed the same pattern in occupation of logs by carpenter ants (Torgersen and Bull 1995), the primary prey of pileated woodpeckers (Beckwith and Bull 1985).

Determining whether wildlife use of particular logs is related to the species or to the size of the log is difficult. In studies by Torgersen and Bull (1995) lodgepole pine, which had the smallest mean diameters of logs, rarely supported populations of the wood-dwelling ants used as food by pileated woodpeckers. Conversely, western larch, Douglas-fir, and grand fir, which had the largest mean diameters, commonly supported these ant colonies. More specifically, the study determined that western larch logs were preferred for pileated woodpecker foraging and for colonization by wood-dwelling ants. Larch also had the greatest mean large-end diameters ( 13 inches) and represented about 14 percent of the logs, but their proportional use was far greater. Douglas-fir, grand fir, and ponderosa pine logs had mean diameters of about 12 inches and represented about 58 percent of the logs in the mixed-conifer study stands. Their use by ants and foraging woodpeckers approximated their representation in the total log resource. Lodgepole pine logs, however, which averaged only 9 inches in large-end diameter and represented 18 percent of the logs, were used much less than their representation among all logs. From the standpoint of ant colonization and woodpecker foraging, log size may be more important than species (Bull and Holthausen 1993, Torgersen and Bull 1995).

Another characteristic describing log resources is the length of logs. This is expressed as mean length of logs or total linear length of logs per acre. Data on lengths of logs in late- and oldstructure mixed-conifer stands in northeastern Oregon indicate that for all species 6 inches or larger in large-end diameter, logs averaged 34 feet. Mean length for logs 15 inches or larger in large-end diameter was 47 feet. Among species for all diameter classes, ponderosa pine averaged the shortest ( 23 feet) and lodgepole pine the longest (45 feet). In these same stands, overall length of logs 6 inches or greater in large-end diameter was 2,064 to 4,928 linear feet per acre. Of this total, there were 175 to 602 linear feet of logs per acre 12 inches or greater in diameter. Logs in this latter size range are the stated size of logs for wildlife habitat in the Regional Forester's Decision Notice to adopt Eastside Forest Plan Amendment No. 2 (U.S. Department of Agriculture 1995). For mixed-conifer stands east of the Cascade Range, this Plan Amendment stipulates 15 to $20 \operatorname{logs}$ per acre, 6 or more feet long, with a total linear length of 100 to 140 feet of $\operatorname{logs} 12$ inches or greater in small-end diameter. The above limited data suggest that the target linear length stipulated in the Plan Amendment is considerably less than observed in 15 study stands (Torgersen 1997).

Studies by Bull and Holthausen (1993) and Torgersen and Bull (1995) reported about 117 logs per acre in 12 latestructure mixed-conifer stands. In these studies, all logs that had at least 6 feet of their length in the 0.1 -acre plots were tallied. This criterion resulted in a misleading density of logs per acre. Further interpretation of only logs whose mid lengths fell within the 0.1-acre plots indicated that the actual number of logs per acre was 24 percent less than the total number of logs entering the plots. Thus, an average number of $88.8 \mathrm{logs}$ per acre (standard error $[\mathrm{SE}]=6.9$ ) more accurately describes the true density of logs in the 12 home ranges of pileated woodpeckers in that study. Using the mean length of 34 feet per log translates to 3,026 linear feet of logs per acre in these home ranges.

Additional research in six stands of old-growth mixed conifers in northeastern Oregon showed an average of 92.9 logs per acre ( $\mathrm{SE}=11.9)$. Inventories in four stands of lateseral mixed conifers in northeastern Oregon showed an average of $88.5 \mathrm{logs}$ per acre $(\mathrm{SE}=14.5)$. The similarity in $\log$ densities among 27 widely distributed stands in four counties in northeastern Oregon suggest that log resources may be quite similar, about 90 logs per acre, in late- and oldseral stands of mixed conifers there (Torgersen 1996).

Inventories of logs in four ponderosa pine stands in northeastern Oregon that were selectively logged for the largest trees about 40 years ago show an average density of 45.5 logs per acre $(\mathrm{SE}=8.3)$ (Torgersen 1996).

Studies conducted in coastal Douglas-fir forests west of the Cascade Range have used percentage of ground covered by $\operatorname{logs}$ as a feature against which to relate abundance of some small vertebrates and their food, particularly hypogeous fungi (truffles and trufflelike fungi) (Amaranthus and others 1994, Carey and Johnson 1995). Percentage of ground covered by logs has not been a habitat feature used to relate to wildlife in the interior Columbia River basin. We suggest that this feature may be a good one to include in assessments of down wood resources. Percentage of ground covered by logs can be calculated from the data we propose be collected in the log sampling form in appendix B. 
Log structural classes-Logs may be in various stages of decomposition, from sound, newly dead trees, to logs that have deteriorated to the point of having nearly blended into the forest floor. Exterior appearance and interior structure differ among logs of various ages just as they do in living trees and snags. Maser and others (1979) classified logs by exterior appearance into log decomposition classes. In contrast, the physical properties of internal structure and wood soundness are here called "wood condition"--the extent to which the wood has become soft, friable, spongy, or pitted as a result of attack by decay-causing organisms and channeling by invertebrates (Torgersen and Bull 1995).

The five log decomposition classes of Maser and others (1979) describe the physical appearance of deteriorating down trees. They characterized the classes by the presence or absence of bark and small twigs, the texture and color of the wood, the shape or amount of decomposition of the log, and the amount of contact of the log with the forest floor.

Unless evidence suggests otherwise, we suggest that three log decomposition classes are sufficient to classify the extent of degradation of fallen trees relative to most wildlife use. Thus we propose three log structural classes (figs. 62 and 63): $\log$ decomposition classes 1 and 2 of Maser and others (1979) are incorporated into log structural class 1, decomposition class 3 becomes structural class 2 , and decomposition classes 4 and 5 become structural class 3 .

Wood condition-Any examination of logs will show a range of external and internal wood conditions. Some logs may be almost uniformly sound or uniformly rotten; others may have sound heartwood but sapwood that has become

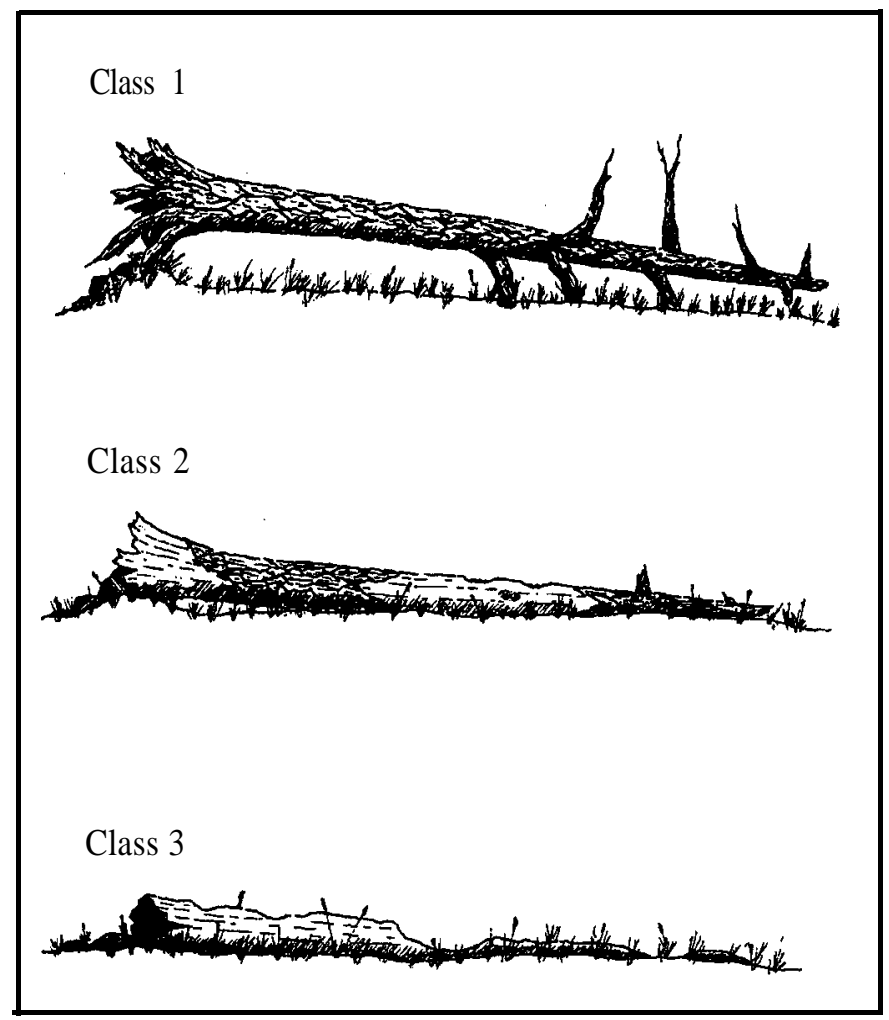

Figure 62-Three structural classes of logs. crumbly as a result of colonization by fungi, beetle larvae, or ants. In northeastern Oregon sites, Torgersen and Bull (1995) used three wood condition classes (sound, moderately decayed, and advanced decay) to describe logs. Discriminant analysis suggested that this variable was only rarely related to either signs of foraging by pileated woodpeckers or presence of ants. Carpenter ants, the dominant prey of pileated woodpeckers, tended to be associated with sound wood, and more specifically with sound, large-diameter western larch.

Assessing wood condition is highly subjective but may be estimated by using a hatchet to chop into the log at intervals along its length. The butt end of a log may be much softer than portions toward the small-diameter end. Because wood conditions vary in a log and because the sampling procedure is subjective, the relevance of wood condition to wildlife use is unclear. Nonetheless, we have included this variable on the sample data form for characterizing down log resources (appendix B). The decision to record wood condition is left to the user.

Hollow logs-Because of the exceptional values of this structural component to wildlife, we propose that this feature be specifically recorded in describing the character of log resources (appendix B).

Inventory of logs-Much study has been devoted to portraying amounts of down material as fire fuels (Fischer 1981a, 1981b, 1981c; Koski and Fischer 1979; Maxwell and Ward 1976, 1980). The breakdown into tonnages or volumes and the photo series for classifying forest residues, however, are of limited utility to biologists who want to describe log resources in ways that are relevant to use by wildlife. Management agencies already need estimates of log resources in stands to assure compliance with stated management goals in planning documents.

A survey of logs along transects and in fixed-size plots can be used to estimate numbers of logs per acre, species composition, and proportion of logs by diameter-class in selected stands (appendix C). The line transect method for assessing log resources was adapted from sampling techniques used to determine volume and tonnage of down woody fuels (Brown 1974, Brown and others 1982). A modification of this method uses 18 clusters of three 75-foot transects to characterize log populations in stands up to about 30 acres (Ottmar 1996). The fixed-plot method uses 18-20 circular or square $1 / 40$ th-acre plots to determine log populations in a 30-acre stand. See appendix $\mathrm{C}$ for detailed descriptions of these sampling schemes.

Information on numbers, sizes, and other characteristics of logs that produce suitable habitat for wildlife is scanty. The information given here is based on our research, which is limited to mixed-conifer stands in known pileated woodpecker home ranges (Bull and Holthausen 1993, Torgersen and Bull 1995) or data from other selected stands in the Blue Mountains of northeastern Oregon (Torgersen 1996). The management options offered above are based on preliminary information, and we anticipate that management will adopt different options as new information becomes available. 


\section{Review}

- Size, species, and number of logs per acre are fundamental descriptors of the suitability of log resources for wildlife.

- Logs 15 inches or greater in large-end diameter are particularly important for species such as pileated woodpeckers.

- In mixed-conifer stands, logs of western larch, Douglasfir, and grand fir were favored for foraging by pileated woodpeckers in northeastern Oregon.

- Late- and old-seral stands of mixed conifers have about 90 logs per acre in northeastern Oregon.

- Logs averaged 34 feet long in mixed-conifer stands in northeastern Oregon, but logs should be as long as possible to offer the greatest range in diameters.

- Hollow logs of any species and size class are important structural components to favor.

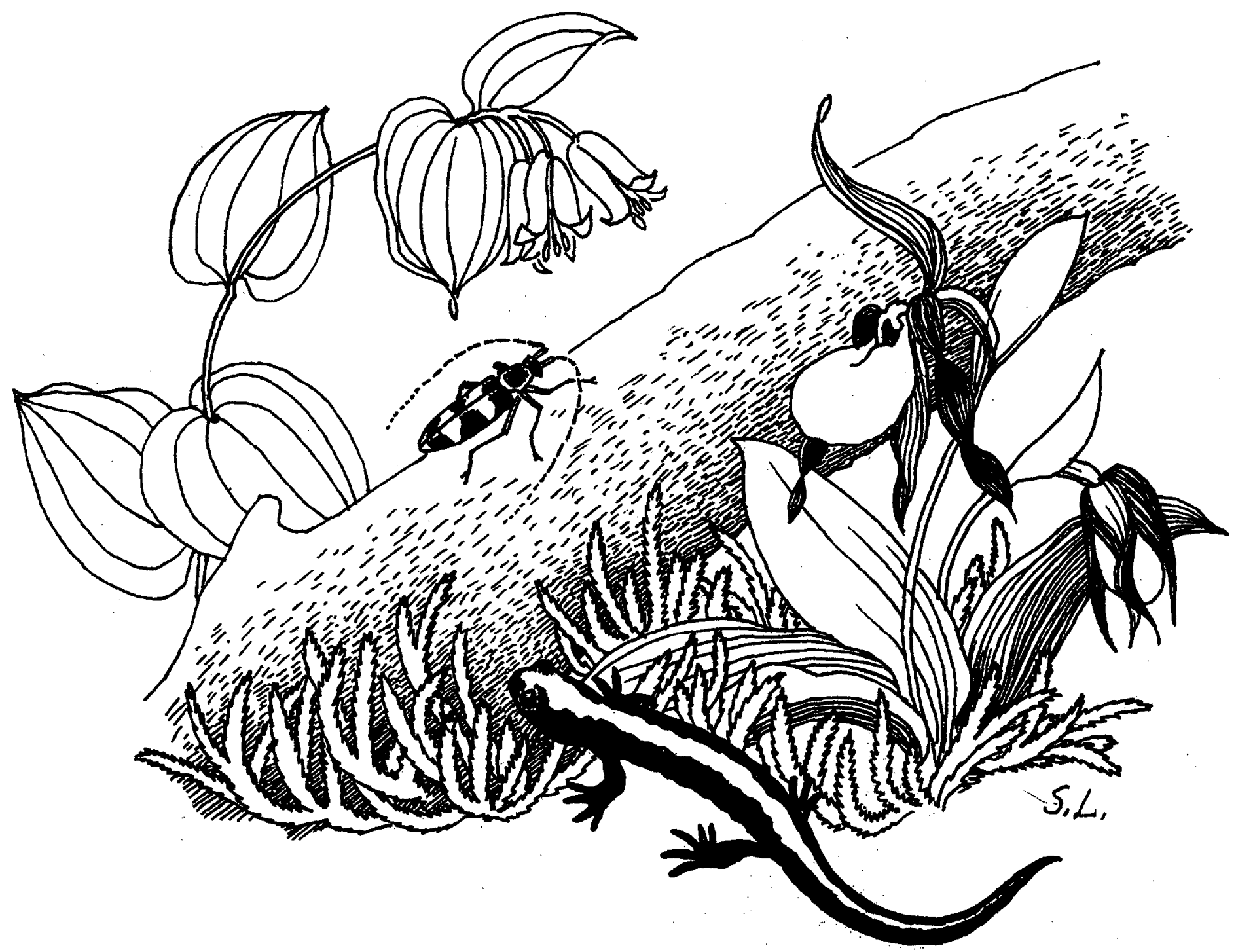




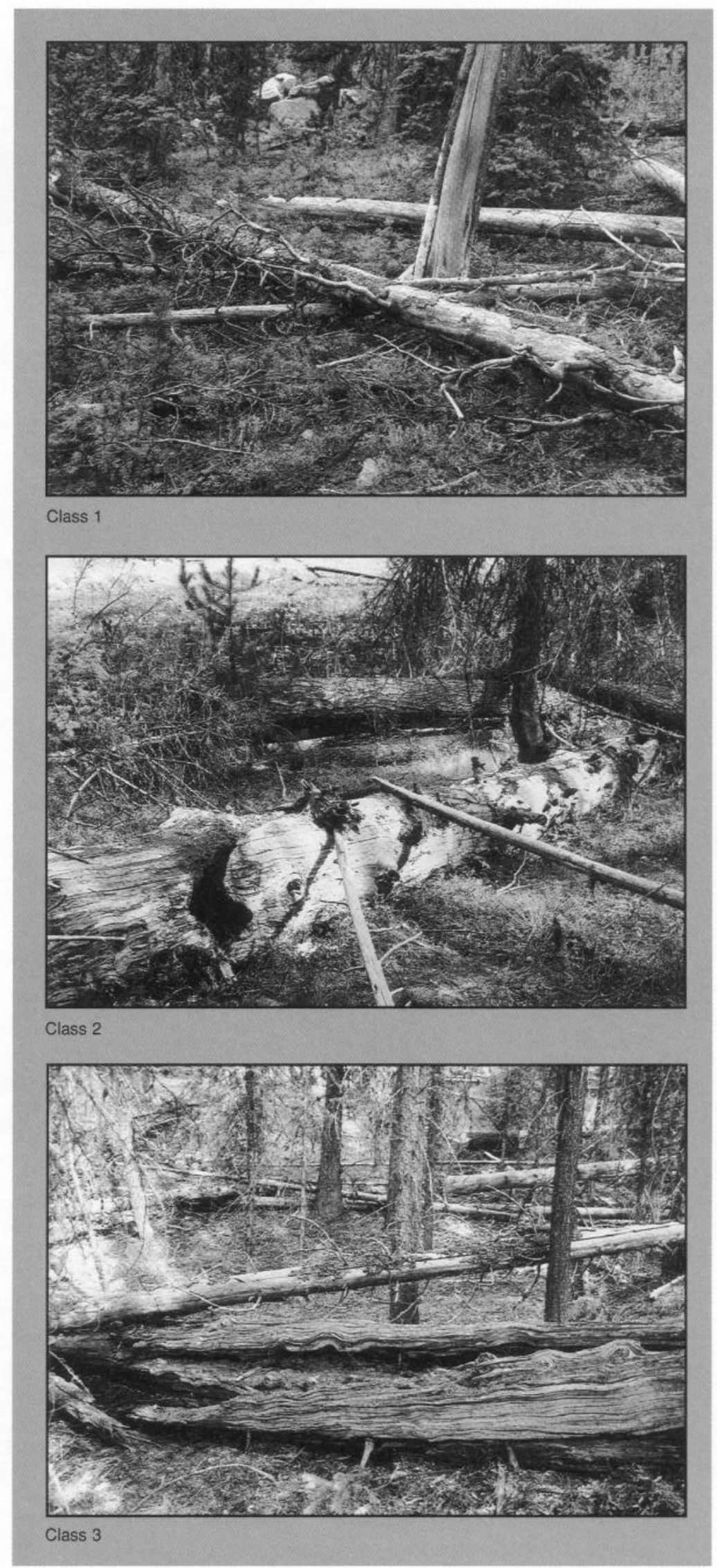

Figure 63-Three structural classes of logs. 


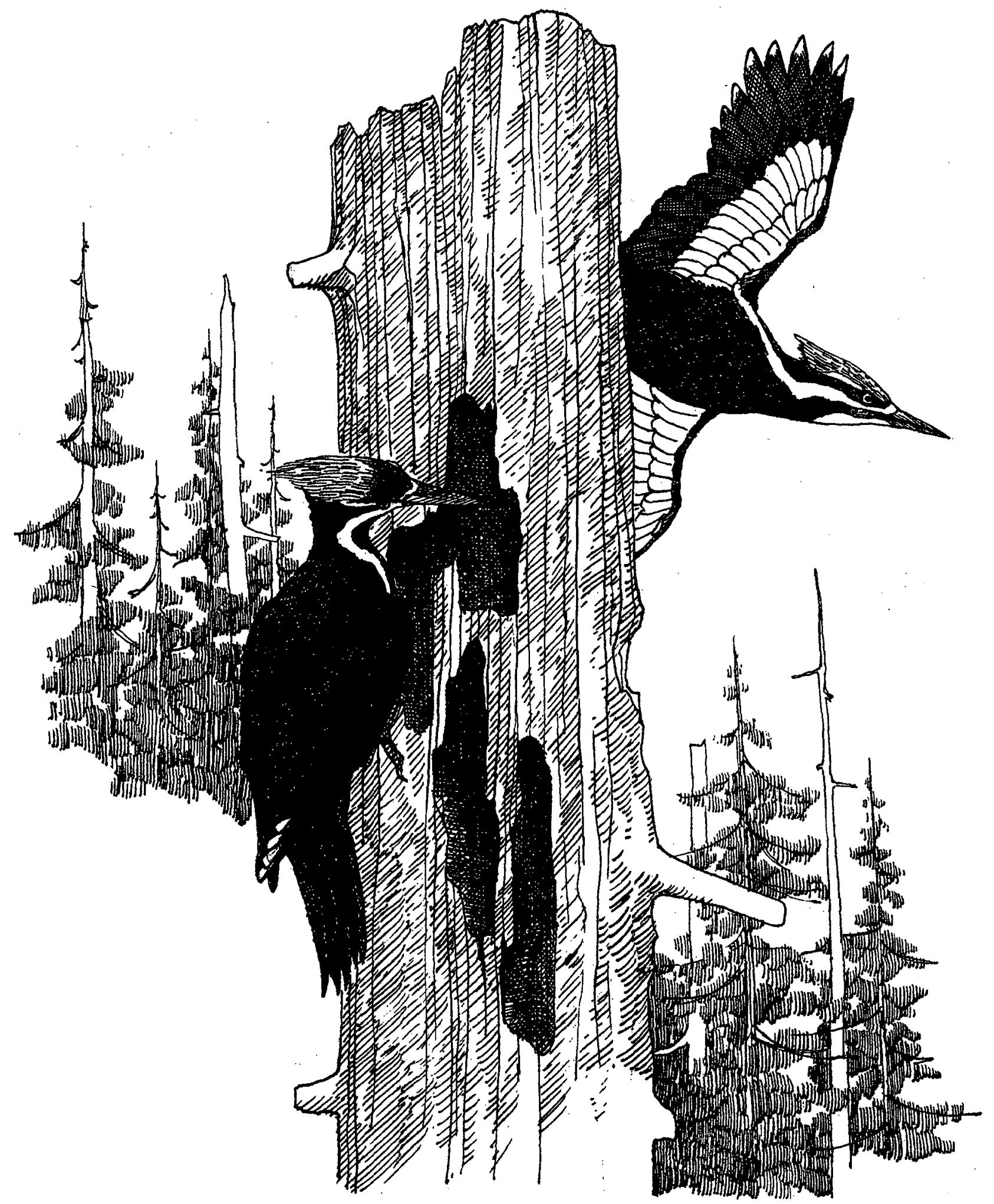




\section{CONCLUSIONS}

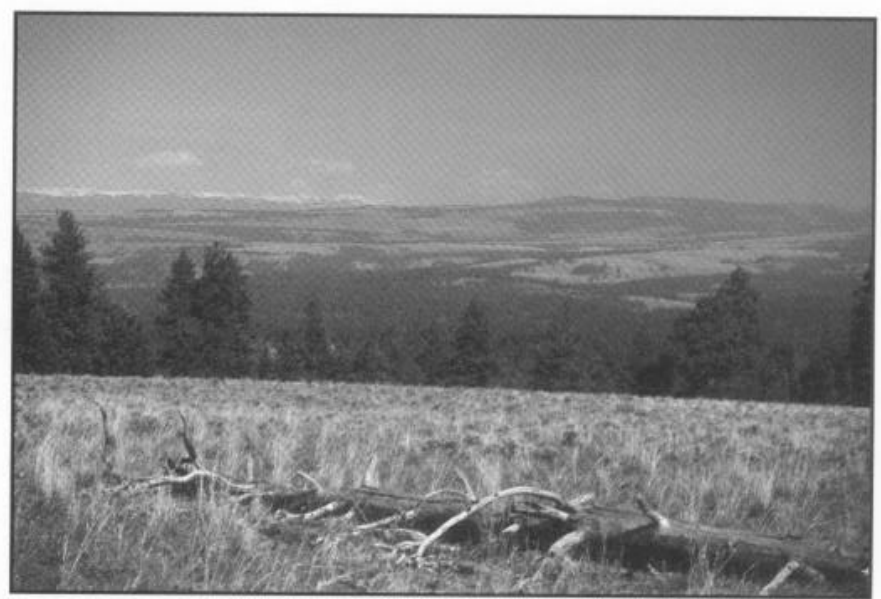

This document presents new information on the retention and selection of trees and logs most valuable to wildlife. This new information may be useful in the forest planning process. As additional information becomes available, agencies can incorporate it into their management guidelines.

Current direction for providing wildlife habitat on public forest lands does not reflect this new information. Since the publication of Thomas and others (1979), new research suggests that to fully meet the needs of wildlife, additional snags and habitat are required for foraging, denning, nesting, and roosting. Although we do not suggest specific numbers of snags to retain by forest type, two recent studies indicate that viable woodpecker populations occurred in areas with about four snags per acre (Bull and Holthausen 1993, Dixon 1995).

We suggest that the next step in snag management should involve creating a model that incorporates the new information on woodpecker foraging substrates (live trees, snags, and logs), home range sizes, number and characteristics of roost trees, multiple occupancy of snags, and needs for other habitat structures. Once this information is incorporated, the model may suggest changes to guidelines that specify numbers of snags and other habitat features by forest type and geographic area. Additional information on fall rates of snags, foraging needs of black-backed and three-toed woodpeckers, relation of the density of woodpeckers to that of secondary cavity nesters, and relation of snag density to woodpecker density would greatly improve the model.

Although hollow trees provide benefits to many wildlife species, no framework regarding their management exists. Additional research is needed to clarify how and when heartrot decay is initiated, and how long hollow trees persist. Management actions that foster the development and retention of hollow trees need to be developed.

In spite of the value of dwarf mistletoe brooms to wildlife, many managers are still reluctant to retain such structures in stands. With creative management, selected areas can be identified in which to retain trees with dwarf mistletoe brooms but still minimize the risk of spread of dwarf mistletoe to the rest of the stand. Information presented here suggests that retaining trees with brooms caused by broom rusts or Elytroderma offers little risk of tree mortality within a stand.

We are just beginning to recognize the importance of logs in wildlife management. Inventories in 22 areas in northeastern Oregon showed that late- and old-seral stands of mixed conifers contained about 90 logs per acre. These inventories raise questions regarding current guidelines that call for only 6 to 20 logs per acre. Logs are important not just for wildlife but for maintenance of nutrient recycling, water economy, and structural properties for plant growth and soil development that logs provide.

For any management plan to be effective, a reasonable estimate of existing conditions is essential. To obtain this information, inventories of snags, logs, hollow trees, and trees with brooms can be done by using techniques recommended in this text. For down logs, the minimum information needed for wildlife purposes are large-end diameters of logs, lengths, and numbers per acre. Fuel inventories do not provide this information. Once existing conditions are known, management direction can dictate the number and type of structures to retain and the number that can be removed without jeopardizing wildlife objectives.

We hope that this document will provide some new and utilitarian information for land managers and planners with which to better manage for wildlife. All of these structures provide diversity in the forest ecosystem that in turn provides diversity in wildlife.

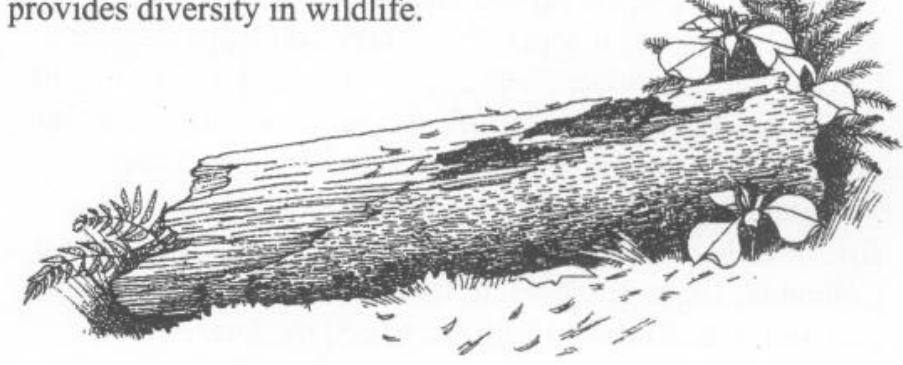




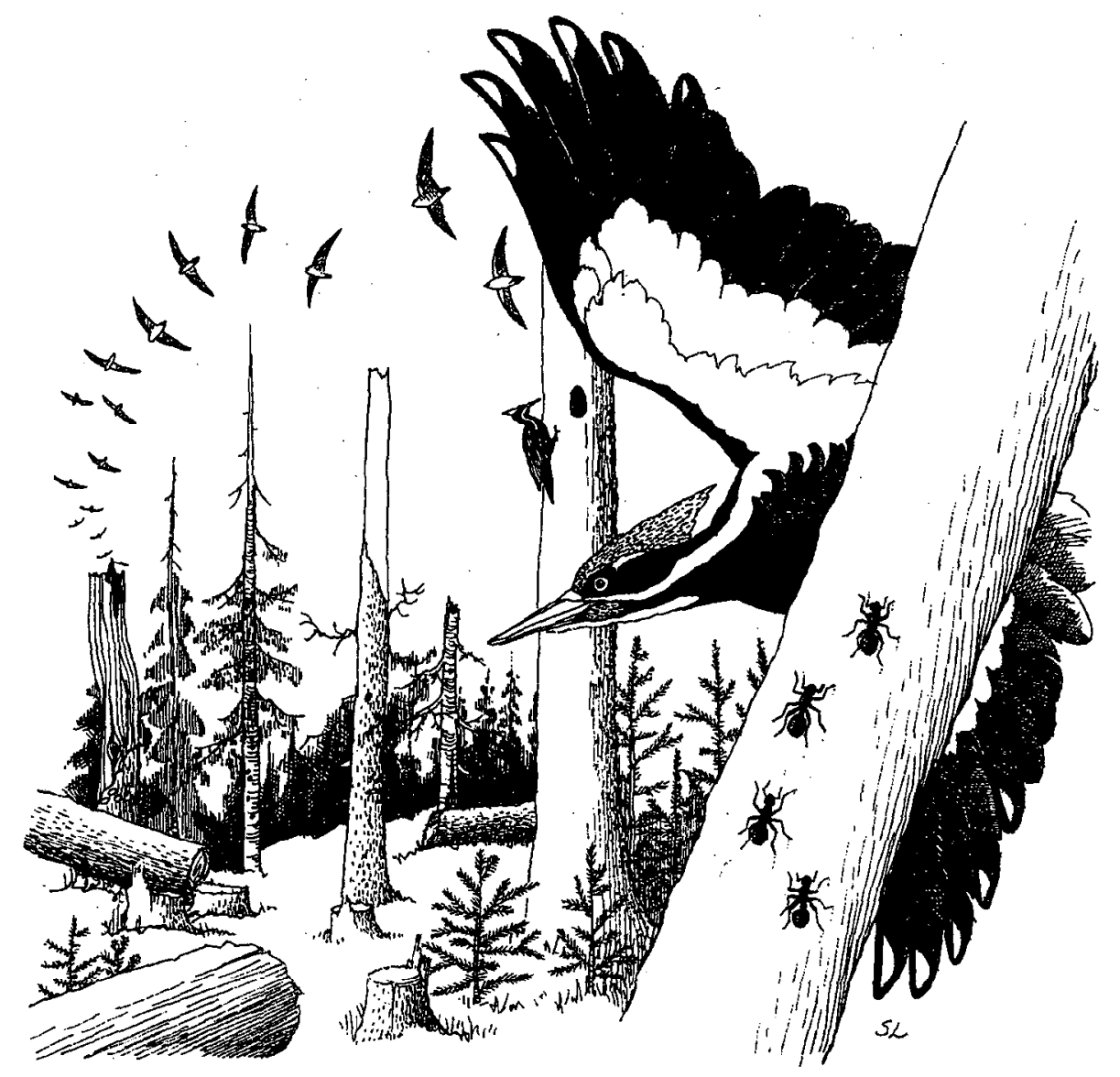

\section{ACKNOWLEDGMENTS}

Additional information was provided by Lisa Bate, Michelle Craig, Rita Dixon, Diane Evans, Riley McClelland, and Victoria Saab. Drawings were provided by Janet Hohmann and Susan Lindstedt. The following people reviewed all or portions of the text:

Thomas Atzet, USDA Forest Service, Grants Pass, OR; Stan Barras, USDA Forest Service, Washington, DC; Lisa Bate, Moscow, ID; Jerry Beatty, USDA Forest Service, Sandy, OR; Martha Brookes, Pacific Northwest Research Station, Corvallis, OR, Diane Evans, Pacific Northwest Research Station, Olympia, WA; Mary Lou Fairweather, USDA Forest Service, Flagstaff, AZ; Gregory Filip, Oregon State University, Corvallis, OR; Russell Graham, Intermountain Research Station, Moscow, ID; Brian Geils, Rocky Mountain Research Station, Flagstaff, AZ; Scott Harrison, British Columbia Ministry of Forests, Prince Rupert, British Columbia; Diane Hildebrand, USDA Forest Service, Portland, OR; Richard Holthausen, USDA Forest Service,
Flagstaff, AZ; Philip Jahns, USDA Forest Service, Klamath Falls, OR, Susan Johnson, USDA Forest Service, Paulina, OR; Helen Maffei, USDA Forest Service, Bend, OR; Robert Mathiasen, Idaho Department of Lands, Couer d'Alene, ID; James McIver, Blue Mounains Natural Resources Institute. La Grande, OR; Kim Mellen, USDA Forest Service, Gresham, OR; Mark Penninger, USDA Forest Service, La Grande, OR, Mary Rowland, La Grande, OR; Victoria Saab, Intermountain Research Station, Boise, ID; Craig Schmitt, USDA Forest Service, La Grande, OR; Karen Shimamoto, USDA Forest Service, Sisters, OR; Lynn Starr, Pacific Northwest Research Station, La Grande, OR; James Stone, USDA Forest Service, Crescent, OR; John Teply, USDA Forest Service, Portland, OR; Robert Tinnin, Portland State University, Portland, OR; Michael Wisdom, USDA Forest Service, La Grande, OR; Shelly Witt, USDA Forest Service, Logan, UT 
Akenson, James J.; Henjum, Mark G. 1994. Black bear den site selection in the Starkey study area. Natural Resource News. La Grande, OR: Blue Mountains Natural Resources Institute. 4(2): 1-2.

Alexander, Martin E.; Hawksworth, Frank G. 1975. Wildland fires and dwarf mistletoes: a literature review of ecology and prescribed burning. Gen. Tech. Rep. RM-14. Fort Collins, CO: U.S. Department of Agriculture, Forest Service, Rocky Mountain Forest and Range Experiment Station. 12 p.

Amaranthus, Michael; Trappe, James M.; Bednar, Larry; Arthur, David. 1994. Hypogeous fungal production in mature Douglas-fir forest fragments and surrounding plantations and its relation to coarse woody debris and animal mycophagy. Canadian Journal of Forest Research. 24(11): 2157-2165.

Bartels, Ronald; Dell, John D.; Knight, Richard L.; Schaefer, Gail. 1985. Dead and down woody material. In: Brown, E. Reade, tech. ed. Management of wildlife and fish habitats in forests of western Oregon and Washington. Part 1: Chapter narratives. Portland, OR: U.S. Department of Agriculture, Forest Service, Pacific Northwest Region: 171 - 186.

Bate, Lisa Jean. 1995. Monitoring woodpecker abundance and habitat in the central Oregon Cascades. Moscow, ID: University of Idaho. 116 p. M.S. thesis.

Bate, Lisa J.; Garton, Edward 0.; Wisdom, Michael J. [In preparation]. Estimating snag and large tree densities and distributions on a landscape for woodpecker management. Gen. Tech. Rep. Portland, OR: U.S. Department of Agriculture, Forest Service, Pacific Northwest Research Station.

Beckwith, Roy C.; Bull, Evelyn L. 1985. Scat analysis of the arthropod component of pileated woodpecker diet. Murrelet. 66: 90-92.

Bega, Robert V., tech. coord. 1978. Diseases of Pacific Coast conifers. Agric. Handb. 521. Washington, DC: U.S. Department of Agriculture. $199 \mathrm{p}$.

Bennetts, Robert E.; White, Gary C.; Hawksworth, Frank G.; Severs, Scott E. 1996. The influence of dwarf mistletoe on bird communities in Colorado ponderosa pine forests. Ecological Applications. 6: 899909.
Bevis, Kenneth R. 1996. Primary cavity excavators in grand fir forests of Washington's east Cascades and forestry on the Yakama Indian Nation, Washington. In: Bradford, Peter; Manning, Todd; l'Anson, Bill, eds. Wildlife tree/ stand-level biodiversity workshop proceedings; 1995 October 17-18; Victoria, BC. Victoria, BC: British Columbia Environment: 77-86.

Boyce, John Shaw. 1938. Forest pathology in forest practice. New York: John Wiley and Sons, Inc. 600 p.

Broadbooks, H.E. 1958. Life history and ecology of the chipmunk, Eutamias amoenus, in eastern Washington. Misc. Publ. 103. Ann Arbor, MI: University of Michigan, Museum of Zoology. $42 \mathrm{p}$.

Brown, H.P.; Panshin, A.J.; Forsaith, C.C. 1949. Textbook of wood technology. Volume 1: Structure, identification, defects, and uses of the commercial woods of the United States. New York: McGraw-Hill. 34 p.

Brown, James K. 1974. Handbook for inventorying downed woody material. Gen. Tech. Rep. INT-16. Ogden, UT: U.S. Department of Agriculture, Forest Service, Intermountain Forest and Range Experiment Station. 24 p.

Brown, James K.; Oberheu, Rick D.; Johnson, Cameron M. 1982. Handbook for inventorying surface fuels and biomass in the Interior West. Gen. Tech. Rep. INT-129. Ogden, UT: U.S. Department of Agriculture, Forest Service, Intermountain Forest and Range Experiment Station. 48 p.

Brown, Timothy K. 1996. Snags and wildlife tree preservation and enhancement. In: Bradford, Peter; Manning, Todd; l'Anson, Bill, eds. Wildlife tree/stand-level biodiversity workshop proceedings; 1995 October 17-18; Victoria, BC. Victoria, BC: British Columbia Environment: 71-75.

Bull, Evelyn L. 1983. Longevity of snags and their use by woodpeckers. In: Snag habitat management: Proceedings of a symposium; 1983 June 7-9; Flagstaff, AZ. Gen. Tech. Rep. RM-99. Fort Collins, CO: U.S. Department of Agriculture, Forest Service, Rocky Mountain Forest and Range Experiment Station: 64-67.

Bull, Evelyn L. 1986. Resource partitioning among woodpeckers in northeastern Oregon. Moscow, ID: University of Idaho. 109 p. Ph.D. dissertation. 
Bull, Evelyn L. 1995. Progress report on American marten home range and habitat use. Portland, OR: U.S. Department of Agriculture, Forest Service, Pacific Northwest Research Station. 21 p. Unpublished report. On file with: Pacific Northwest Research Station, Forestry and Range Sciences Laboratory, 1401 Gekeler Lane, La Grande, OR 97850.

Bull, Evelyn L. 1996a. Use of hollow trees by Vaux's swifts. Portland, OR: U.S. Department of Agriculture, Forest Service, Pacific Northwest Research Station. 2 p. Unpublished data. On file with: Pacific Northwest Research Station, Forestry and Range Sciences Laboratory, 1401 Gekeler Lane, La Grande, OR 97850.

Bull, Evelyn L. 1996b. Owl nests in brooms caused by dwarf mistletoe and Elytroderma disease. Portland, OR: U.S. Department of Agriculture, Forest Service, Pacific Northwest Research Station. 4 p. Unpublished data. On file with: Pacific Northwest Research Station, Forestry and Range Sciences Laboratory, 1401 Gekeler Lane, La Grande, OR 97850.

Bull, Evelyn L. 1996c. Longevity of created snags. Portland, OR: U.S. Department of Agriculture, Forest Service, Pacific Northwest Research Station. 25 p. Unpublished data. On file with: Pacific Northwest Research Station, Forestry and Range Sciences Laboratory, 1401 Gekeler Lane, La Grande, OR 97850.

Bull, Evelyn L.; Collins, Charles T. 1993. Vaux's swift (Chaetura vanxi). In: Poole, A.; Gill, E., eds. The birds of North America, No. 77. Philadelphia, PA: The Academy of Natural Sciences; Washington, DC: The American Ornithologists' Union. $12 \mathrm{p}$.

Bull, Evelyn L.; Henjum, Mark G. 1990. Ecology of the great gray owl. Gen. Tech. Rep. PNW-265. Portland, OR: U.S. Department of Agriculture, Forest Service, Pacific Northwest Research Station. 39 p.

Bull, Evelyn L.; Holthausen, Richard S. 1993. Habitat use and management of pileated woodpeckers in northeastern Oregon. Journal of Wildlife Management. 57: 335-345.

Bull, Evelyn L.; Holthausen, Richard S.; Henjum, Mark G. 1992. Roost trees used by pileated woodpeckers in northeastern Oregon. Journal of Wildlife Management. 56: 786-793.

Bull, Evelyn L.; Holthausen, Richard S.; Marx, David B. 1990. How to determine snag density. Western Journal of Applied Forestry. 5: 56-58.

Bull, Evelyn L.; Partridge, Arthur D. 1986. Methods of killing trees for use by cavity nesters. Wildlife Society Bulletin. 14: 142-146.
Bull, Evelyn L.; Twombly, Asa D.; Quigley, Thomas M. 1980. Perpetuating snags in managed mixed conifer forests of the Blue Mountains, Oregon. In: Management of western forests and grasslands for nongame birds, workshop proceedings; 1980 February 11-14; Salt Lake City, UT. Gen. Tech. Rep. INT-86. Ogden, UT: U.S. Department of Agriculture, Forest Service, Intermountain Forest and Range Experiment Station: 325-336.

Bull, Evelyn L.; Wright, Anthony L.; Henjum, Mark G. 1989. Nesting and diet of long-eared owls in conifer forests, Oregon. Condor. 91: 908-912.

Burnett, Gary W. 1981. Movements and habitat use of American marten in Glacier National Park, Montana. Missoula, MT: University of Montana. 130 p. M.S. thesis.

Buskirk, Steven W.; Harlow, Henry J.; Forrest, Steven C. 1987. Studies on the resting site ecology of marten in the central Rocky Mountains. In: Troendle, Charles A.;

Kaufmann, Merrill R.; Hamre, R.H.; Winokur, R.P., tech. coords. Management of subalpine forests: building on 50 years of research: Proceedings of a technical conference; 1987 July 6-9; Silver Creek, CO. Gen. Tech. Rep. RM149. Fort Collins, CO: U.S. Department of Agriculture, Forest Service, Rocky Mountain Forest and Range Experiment Station: 150-153.

Campbell, Thomas M., III. 1979. Short-term effects of timber harvests on pine marten ecology. Fort Collins, CO: Colorado State University. 71 p. M.S. thesis.

Carey, Andrew B.; Johnson, Murray L. 1995. Small mammals in managed, naturally young, and old-growth forests. Ecological Applications. 5(2): 336-352.

Chambers, Carol. 1997. Personal communication, associate professor. Northern Arizona University, Department of Ecosystem Management, Box 15018, Flagstaff, AZ 86001.

Childs, T.W.; Shea, Keith R.; Stewart, James L. 1971. Elytroderma disease of ponderosa pine. [Leaflet 42.] [Portland, OR]: U.S. Department of Agriculture, Forest Service, Forest Insect and Disease. 6 p.

Cimon, Norm. 1983. A simple model to predict snag levels in managed forests. In: Snag habitat management: Proceedings of a symposium; 1983 June 7-9; Flagstaff, AZ. Fort Collins, CO: U.S. Department of Agriculture, Forest Service, Rocky Mountain Forest and Range Experiment Station: 200-204.

Clary, Warren P.; Larson, Fredrick R. 1971. Elk and deer use are related to food sources in Arizona ponderosa pine. Res. Note 202. Fort Collins, CO: U.S. Department of Agriculture, Forest Service, Rocky Mountain Forest and Range Experiment Station. 4 p. 
Conner, Richard N.; Locke, Brian A. 1982. Fungi and redcockaded woodpecker cavity trees. Wilson Bulletin. 94: 64-70.

Craig, Michelle FIury. 1995. Pierce District cumulative effects analysis process for snag habitat. Kamiah, ID: U.S. Department of Agriculture, Forest Service, Pierce Ranger District. 5 p. Unpublished report. On file with: Pierce Ranger District, Route 2, Box 191, Kamiah, ID 83536.

Craighead, John J.; Craighead, Frank C.; Roff, Robert L.; O'Gara, Bart W. 1973. Home ranges and activity patterns of nonmigratory elk of the Madison Drainage herd as determined by biotelemetry. Wildlife Monograph. 33: 1-50.

Dahms, Walter G. 1949. How long do ponderosa pine snags stand? Res. Note 57. Portland, OR: U.S. Department of Agriculture, Forest Service, Pacific Northwest Forest and Range Experiment Station. 3 p.

De Vries, P.G. 1973. A general theory on line intersect sampling with application to logging residue inventory. Wageningen, The Netherlands: Mededelingen Landbouwhogeschool 73-11. 23 p.

Dimock, Edward J., II. 1974. Animal populations and damage. In: Environmental effects of forest residues management in the Pacific Northwest: a state-of-knowledge compendium. Gen. Tech. Rep. PNW-24. Portland, OR: U.S. Department of Agriculture, Forest Service, Pacific Northwest Forest and Range Experiment Station: 1-28.

Dixon, Rita Dianne. 1995. Ecology of white-headed woodpeckers in the central Oregon Cascades. Moscow, ID: University of Idaho. 148 p. M.S. thesis.

Evans, Diane; Martens, Dean. 1995. Snag and coarse woody debris guidelines for timber harvest projects. McCall, ID: Payette National Forest. 24 p.

Fairweather, Mary Lou. 1995. Post-treatment biological evaluation of the 1981 Tusayan dwarf mistletoe (DM) control project. Albuquerque, NM: U.S. Department of Agriculture, Forest Service, Southwestern Region. 8 p.

Fischer, William C. 1981a. Photo guide for appraising downed woody fuels in Montana forests: grand fir-larchDouglas-fir, western hemlock, western hemlock-western redcedar, and western redcedar cover types. Gen. Tech. Rep. INT-96. Odgen, UT: U.S. Department of Agriculture, Forest Service, Intermountain Forest and Range Experiment Station. $53 \mathrm{p}$.

Fischer, William C. 1981b. Photo guide for appraising downed woody fuels in Montana forests: interior ponderosa pine, ponderosa pine-larch-Douglas-fir, larchDouglas-fir, and interior Douglas-fir cover types. Gen.
Tech. Rep. INT-97. Odgen, UT: U.S. Department of Agriculture, Forest Service, Intermountain Forest and Range Experiment Station. 133 p.

Fischer, William C. 1981c. Photo guide for appraising downed woody fuels in Montana forests: lodgepole pine, and Engelmann spruce-subalpine fir cover types. Gen. Tech. Rep. INT-98. Ogden, UT: U.S. Department of Agriculture, Forest Service, Intermountain Forest and Range Experiment Station. 143 p.

Forsman, Eric D.; Meslow, E. Charles; Wight, Howard M. 1984. Distribution and biology of the spotted owl in Oregon. Wildlife Monograph. 87: 1-64.

Gartner, Barbara L. 1995. Patterns of xylem variation within a tree. In: Gartner, Barbara L., ed. Plant stems: physiology and functional morphology. New York: Academic Press: 125-145.

Goggans, Rebecca; Dixon, Rita; Seminara, L. Claire. 1988. Habitat use by three-toed and black-backed woodpeckers, Deschutes National Forest, Oregon. Nongame Rep. 87-3-02. [Portland, OR]: Oregon Department of Fish and Game. 49 p.

Hamilton, R.J.; Marchinton, R.L. 1980. Denning and related activities of black bears in the coastal plain of North Carolina. International Conference of Bear Research and Management. 4: 121-126.

Hann, Wendel J.; Jones, Jeffrey L.; Karl, Michael G. [and others]. [In press]. Landscape dynamics of the basin. In: Quigley, Thomas M.; Arbelbide, S.J., tech. eds. An assessment of ecosystem components in the interior Columbia basin and portions of the Klamath and Great Basins. Gen. Tech. Rep. Portland, OR: U.S. Department of Agriculture, Forest Service, Pacific Northwest Research Station. Chapter 3. (Quigley, Thomas M., ed. Interior Columbia Basin Ecosystem Management Project: scientific assessment).

Harmon, Mark E.; Franklin, Jerry F.; Swanson, Fredrick J. [and others]. 1986. Ecology of coarse woody debris in temperate ecosystems. In: MacFadyen, A; Ford, E.D., eds. Advances in ecological research. Orlando, FL: Academic Press, Inc. 15: 133-302.

Harrison, Scott. 1996. Personal communication, wildlife habitat ecologist. British Columbia Ministry of Forests, Research Section, 1011 4th Avenue, Prince George, BC. Canada V2L 3H9.

Hawksworth, Frank G. 1992. Personal communication, research forest pathologist (deceased). Rocky Mountain Forest and Range Experiment Station, 240 W. Prospect Rd., Fort Collins, CO 80526-2098. 
Hawksworth, Frank G.; Nicholls, Thomas H.; Merrill, Laura M. 1987. Long-distance dispersal of lodgepole pine dwarf mistletoe. In: Troendle, Charles A.;

Kauhnann, Merrill R.; Hamre, R.H.; Winokur, R.P., tech. coords. Management of sublpine forests: building on 50 years of research: Proceedings of a conference; 1987 July 6-9; Silver Creek, CO. Gen. Tech. Rep. RM-149. Fort Collins, CO: U.S. Department of Agriculture, Forest Service, Rocky Mountain Forest and Range Experiment Station: 220-226.

Hawksworth, Frank G.; Shaw, Charles G., III. 1984. Damage and loss caused by dwarf mistletoes in coniferous forests of western North America. In: Wood, R.K.S.; Jellis, G.J., eds. Plant diseases: infection, damage and loss. Oxford: Blackwell Scientific Publications: 285-297.

Hawksworth, Frank G.; Wiens, Delbert. 1996. Dwarf mistletoes: biology, pathology, and systematics. Geils, B.; Nisley, R., eds. Agric. Handb. 709. Washington, DC: U.S. Department of Agriculture. $410 \mathrm{p}$.

Henjum, Mark; Akenson, James. 1996. Personal communication, wildlife biologists, Oregon Department of Fish and Wildlife, 107 20th Street, La Grande, OR 97850.

Hepting, George H. 1971. Diseases of forest and shade trees of the United States. Agric. Handb. 386. Washington, DC: U.S. Department of Agriculture. 658 p.

Hessburg, Paul F.; Mitchell, Russel G.; Filip, Gregory M. 1994. Historical and current roles of insects and pathogens in eastern Oregon and Washington forested landscapes. Gen. Tech. Rep. PNW-327. Portland, OR: U.S. Department of Agriculture, Forest Service, Pacific Northwest Research Station. 72 p.

Hinds, Thomas E.; Hawksworth, Frank G.; Davidson, Ross W. 1965. Beetle-killed Engelmann spruce--its deterioration in Colorado. Journal of Forestry. 63: 536542.

\section{Hooper, Robert G.; Lennartz, Michael R.; Muse, H.} David. 1991. Heart rot and cavity tree selection by redcockaded woodpeckers. Journal of Wildlife Management. 55: 323-327.

Hooven, Edward F. 1971. The porcupine in Oregon: its life history and control. Res. Publ. 10. Corvallis, OR: Oregon State University, Forest Research Laboratory. 22 p.

Johnson, Mark K.; Carey, Andrew B. 1979. Porcupine pellet $\mathrm{pH}$, color, and composition. Southwestern Naturalist. 24: 544-545.

Keen, F.P. 1955. The rate of natural falling of beetle-killed ponderosa pine snags. Journal of Forestry. 53: 720-723.
Kimmey, James W. 1955. Rate of deterioration of fire-killed timber in California. Circular 962. Washington, DC: U.S. Department of Agriculture. $22 \mathrm{p}$.

Koehler, Gary M.; Aubry, Keith B. 1994. Lynx. In: Ruggiero, Leonard F.; Aubry, Keith B. [and others], tech. eds. The scientific basis for conserving forest carnivores. Gen. Tech. Rep. RM-254. Fort Collins, CO: U.S. Department of Agriculture, Forest Service, Rocky Mountain Forest and Range Experiment Station: 74-98.

Koski, Wayne H.; Fischer, William C. 1979. Photo series for appraising thinning slash in northern Idaho: western hemlock, grand fir, and western redcedar timber types. Gen. Tech. Rep. INT-46. Ogden, UT: U.S. Department of Agriculture, Forest Service, Intermountain Forest and Range Experiment Station. 50 p.

Lawrence, William H. 1957. Porcupine control: a problem analysis. Forestry Research Notes. Centralia, WA: Weyerhaeuser Timber Company. 43 p.

Leach, Howard R; Hiele, Jack L. 1957. Food habits of the Tehama deer herd. California Fish and Game. 43: 161-178.

Lemons, Daniel Eugene. 1978. Small mammal dissemination of dwarf mistletoe seeds. Portland, OR: Portland State University. 38 p. M.S. thesis.

Li, P.; Martin, T.E. 1991. Nest-site selection and nesting success of cavity-nesting birds in high elevation forest drainages. Auk. 108: 405-418.

Lofroth, Eric C. 1993. Scale dependent analyses of habitat selection by marten in the sub-boreal spruce biogeoclimatic zone, British Columbia. Burnaby, BC: Simon Fraser University. 109 p. M.S. thesis.

Lofroth, Eric C. [In press]. The dead wood cycle. In Voller, Joan; Harrison, Scott, eds. Conservation biology principles for forested landscapes. Vancouver, BC: University of British Columbia Press. [Pages unknown]. Chapter 8.

Lyon, Jack L. 1977. Attrition of lodgepole pine snags on the Sleeping Child Bum, Montana. Res. Note INT-219. Ogden, UT: U.S. Department of Agriculture, Forest Service, Intermountain Forest and Range Experiment Station. 4 p.

Machmer, Marlene M.; Steeger, Christoph. 1995. The ecological roles of wildlife tree users in forest ecosystems. Victoria, BC: British Columbia Ministry of Forests. 54 p.

Manion, Paul D. 1981. Tree disease concepts. Englewood Cliffs, NJ: Prentice-Hall, Inc. 399 p. 
Martin, Sandra K.; Beatty, Jerome S.; Hawksworth, Frank G. 1992. Douglas-fir dwarf mistletoe brooms and spotted owl nesting habitat, eastern Cascade Range, Washington. In: Frankel, Susan, comp. Proceedings, 40th annual western international forest disease work conference; 1992 July 13-17; Durango, CO. San Francisco, CA: U.S. Department of Agriculture, Forest Service, Forest Pest Management: 77-79.

Martinka, Robert R. 1972. Structural characteristics of blue grouse territories in southwestern Montana. Journal of Wildlife Management. 36: 498-5 10.

Maser, Chris; Anderson, Ralph G.; Cromack, Kermit, Jr. [and others]. 1979. Dead and down woody material. In: Thomas, Jack Ward, tech. ed. Wildlife habitats in managed forests: the Blue Mountains of Oregon and Washington. Agric. Handb. 553. Washington, DC: U.S. Department of Agriculture: 78-95.

Maser, Chris; Trappe, James M., tech. eds. 1984. The seen and unseen world of the fallen tree. Gen. Tech. Rep. PNW-164. Portland, OR: U.S. Department of Agriculture, Forest Service, Pacific Northwest Research Station. $56 \mathrm{p}$.

Mathiasen, Robert L. 1996. Dwarf mistletoes in forest canopies. Northwest Science. 70: 61-71.

Maxwell, Wayne G.; Ward, Franklin R. 1976. Photo series for quantifying forest residues in the: ponderosa pine type, ponderosa pine and associated species type, lodgepole pine type. Gen. Tech. Rep. PNW-52. Portland, OR: U.S. Department of Agriculture, Forest Service, Pacific Northwest Forest and Range Experiment Station. $73 \mathrm{p}$.

Maxwell, Wayne G.; Ward, Franklin R. 1980. Photo series for quantifying natural forest residues in common vegetation types of the Pacific Northwest. Gen. Tech. Rep. PNW-105. Portland, OR: U.S. Department of Agriculture, Forest Service, Pacific Northwest Research Station. 230 p.

McClelland, Bernard Riley. 1977. Relationships between hole-nesting birds, forest snags, and decay in western larch-Douglas-fir forests of the northern Rocky Mountains. Missoula, MT: University of Montana. 483 p. Ph.D. dissertation.

McClelland, B. Riley; Frissell, Sidney S.; Fischer, William C.; Halvorson, Curtis H. 1979. Habitat management for hole nesting birds in forests of western larch and Douglas-fir Journal of Forestry. 77: 480-483.

Mellen, Teresa Kim. 1987. Home range and habitat use of pileated woodpeckers, western Oregon. Corvallis, OR: Oregon State University. 96 p. M.S. thesis.
Mielke, James L. 1950. Rate of deterioration of beetle-killed Engehnann spruce. Journal of Forestry. 48: 882-888.

Mowrey, Robert A.; Zasada, J.C. 1984. Den tree use and movements of northern flying squirrels in interior Alaska and implications for forest managers. In: Meehan, William R.; Merrell, T.R.; Hanley, Thomas A., eds. Fish and wildlife relationships in old-growth forests: Proceedings of a symposium; 1982 April 12-15; Juneau, AK. Morehead City, NC: American Institute of Fishery Research Biologists: 351-356.

Nagorsen, David W.; Brigham, R. Mark. 1993. Bats of British Columbia. Volume 1: The mammals of British Columbia. Royal British Columbia Museum Handbook. Vancouver, BC: University of British Columbia Press.

Nicholls, Thomas H.; Hawksworth, Frank G.; Merrill, Laura M. 1984. Animal vectors of dwarf mistletoe, with special reference to Arceuthobium americanurn on lodgepole pine. In: Hawksworth, F.G.; Scharpf, R.F., eds. Biology of dwarf mistletoes: Proceedings of a symposium; 1984 August 8; Fort Collins, CO. Gen. Tech. Rep. RM- 111. Fort Collins, CO: U.S. Department of Agriculture, Forest Service, Rocky Mountain Forest and Range Experiment Station: 102- 110.

Neitro, William A.; Binkley, Virgil W.; Cline, Steven P. [and others]. 1985. Snags (wildlife trees). In Brown E. Reade, tech. ed. Management of wildlife and fish habitats in forests of western Oregon and Washington. Part 1: Chapter narratives. Portland, OR U.S. Department of Agriculture, Forest Service, Pacific Northwest Region: 129- 169.

Noble, William 0.; Meslow, E. Charles; Pope, Michael D. 1990. Denning habits of black bears in the central Coast Range of Oregon. Corvallis, OR: Oregon State University, Department of Fisheries and Wildlife. [Pages unknown].

Ottmar, Roger. 1996. Personal communication, research forester, Pacific Northwest Research Station, Forestry Sciences Laboratory, 4043 Roosevelt Way NE, Seattle, WA 98105-6497.

Parks, Catherine G. 1996a. Bear trees--an eastern Oregon landscape legacy. [Brochure]. Portland, OR: U.S. Department of Agriculture, Forest Service, Pacific Northwest Research Station. [Not paged].

Parks, Catherine G. 1996b. Woodpecker use and longevity of snags created by killing ponderosa pine infected with dwarf mistletoe. Portland, OR: U.S. Department of Agriculture, Forest Service, Pacific Northwest Research Station. 5 p. Unpublished report. On file with: Pacific Northwest Research Station, Forestry and Range Sciences Laboratory, 1401 Gekeler Lane, La Grande, OR 97850. 
Parks, Catherine G.; Bull, Evelyn L.; Filip, Gregory M. 1996a. Using artificially inoculated decay fungi to create wildlife habitat. In: Bradford, Peter; Manning, Todd; l'Anson, Bill, eds. Wildlife tree/stand-level biodiversity workshop proceedings; 1995 October 17-18; Victoria, BC. Victoria, BC: British Columbia Environment: 87-89.

Parks, Catherine G.; Bull, Evelyn L.; Filip, Gregory M.; Gilbertson, R.L. 1996b. Wood decay fungi associated with woodpecker nest cavities in living western larch. Plant Disease. 80: 959.

Parks, Catherine G.; Bull, Evelyn L.; Torgersen, Torolf R. [In press]. Field guide to the identification of snags and logs in the interior Columbia River basin. Gen. Tech. Rep. PNW-390. Portland, OR: U.S. Department of Agriculture, Forest Service, Pacific Northwest Research Station. 41 p.

Parks, C.G.; Raley, CM.; Aubry, K.B.; Gilbertson, R.L. 1997. Wood decay associated with pileated woodpecker roosts in western redcedar. Plant Disease 81:551.

Parks, Catherine G.; Shaw, David C. 1996. death and decay: a vital part of living canopies. Northwest Science. 70: 46-53.

Parmeter, J.R. 1978. Forest stand dynamics and ecological factors in relation to dwarf mistletoe spread, impact, and control. In: Proceedings of the symposium on dwarf mistletoe control through forest management. Gen. Tech. Rep. PSW-31: Berkeley, CA: U.S. Department of Agriculture, Forest Service, Pacific Southwest Forest and Range Experiment Station: 16-30.

Pickford, Stewart G.; Hazard, John W. 1978. Simulation studies on line transect sampling of forest residue. Forest Science. 4: 469-483.

Powell, Roger A.; Ziellnski, William J. 1994. Fisher. In: Ruggiero, Leonard F.; Aubry, Keith B. [and others], tech. eds. The scientific basis for conserving forest carnivores. Gen. Tech. Rep. RM-254. Fort Collins, CO: U.S. Department of Agriculture, Forest Service, Rocky Mountain Forest and Range Experiment Station: 38-73.

Raphael, Martin G.; White, M. 1984. Use of snags by cavity-nesting birds in the Sierra Nevada. Wildlife Monograph. 86: 1-66.

Rayner, A.D.M.; Boddy, Lynne. 1988. Fungal decomposition of wood--its biology and ecology. New York: John Wiley and Sons. 587 p.

Reynolds, Richard T.; Graham, Russell T.; Reiser, M. Hildegard. 1992. Management recommendations for the northern goshawk in the Southwestern United States.
Gen. Tech. Rep. RM-217. Fort Collins, CO: U.S. Department of Agriculture, Forest Service, Rocky Mountain Forest and Range Experiment Station. 90 p.

Reynolds, Richard T.; Meslow, E. Charles; Wight, Howard M. 1982. Nesting habitat of coexisting accipiters in Oregon. Journal of Wildlife Management. 46: 124- 138.

Saab, Victoria A.; Dudley, Jonathan. 1997. Responses by cavity-nesting birds to high-intensity wildfire and postfire salvage logging in ponderosa pine/Douglas-fir forests of southwestern Idaho. Boise, ID: U.S. Department of Agriculture, Forest Service, Intermountain Research Station; progress report. $34 \mathrm{p}$.

Schmid, J.M.; Mata, S.A.; McCambridge, W.F. 1985. Natural falling of beetle-killed ponderosa pine. Res. Note RM-454. Fort Collins, CO: U.S. Department of Agriculture, Forest Service, Rocky Mountain Forest and Range Experiment Station. 4 p.

Schommer, Tim; Collard, Ernie; Widenmann, Kurt. 1993. Wallowa-Whitman National Forest green tree snag replacement guidelines. Baker, OR: U.S. Department of Agriculture, Forest Service, Pacific Northwest Region, Wallowa-Whitman National Forest. 14 p.

Scott, Donald W.; Schmitt, Craig L. 1996. Report on forest health on National Forest lands in the Blue Mountains, 1990-1996: insects and diseases. Portland, OR: U.S. Department of Agriculture, Forest Service, Pacific Northwest Region. [Pages unknown]. Administrative report BMZ-96-12. On file with: Blue Mountains Pest Management Zone, 1401 Gekeler Lane, La Grande, OR 97850.

Severson, K.E. 1986. Spring and early summer habitats and foods of male blue grouse in Arizona. Journal of the Arizona-Nevada Academy of Science. 21: 13-18.

Shain, Louis. 1995. Stem defense against pathogens. In: Gartner, B., ed. Plant stems--physiology and functional morphology. San Diego, CA: Academic Press: 383-401.

Smith, Graham W. 1982. Habitat use by porcupines in a ponderosa pine/Douglas-fir forest in northeastern Oregon. Northwest Science. 56: 236-240.

Spencer, Wayne D. 1987. Seasonal rest-site preferences of pine martens in the northern Sierra Nevada. Journal of Wildlife Management. 51: 616-621.

Sperry, John S. 1995. Limitations on stem water transport and their consequences. In: Gartner, B., ed. Plant stems-physiology and functional morphology. San Diego, CA: Academic Press: 105-120. 
Stauffer, Dean F.; Peterson, Steven R. 1986. Seasonal microhabitat relationships of blue grouse in southeastern Idaho. Great Basin Naturalist. 46: 117-122.

Steeger, Christoph; Machmer, Marlene. 1995. Wildlife trees and their use by cavity nesters in selected stands of the Nelson Forest Region. Tech. Rep. 010. Nelson, BC: Canada Ministry of Forests. 28 p.

Steeger, Christoph; Machmer, Marlene. 1996. Use of trees by cavity nesters in managed and unmanaged interior cedar-hemlock stands of southern British Columbia. In: Bradford, Peter; Manning, Todd; 1'Anson, Bill, eds. Wildlife tree/stand-level biodiversity workshop proceedings; 1995 October 17-18; Victoria, BC. Victoria, BC: British Columbia Environment: 45-54.

Thomas, Jack Ward; Anderson, Ralph G.; Maser, Chris; Bull, Evelyn L. 1979. Snags. In: Thomas, Jack Ward, ed. Wildlife habitats in managed forests: the Blue Mountains of Oregon and Washington. Agric. Handb. 553. Washington, DC: U.S. Department of Agriculture, Forest Service: 60-77.

Tinnin, Robert 0.; Knutson, Donald M. 1982. Witches' broom formation in conifers infected by Arceuthobium spp: an example of parasitic impact upon community dynamics. American Midland Botanist. 107: 351-359.

Tinnin, Robert 0.; Knutson, Donald M. 1985. How to identify brooms in Douglas-fir caused by dwarf mistletoe. Res. Note PNW-426. Portland, OR: U.S. Department of Agriculture, Forest Service, Pacific Northwest Research Station. 8 p.

Tobalske, Bret W. 1992. Evaluating habitat suitability using relative abundance and fledging success of red-naped sapsuckers. Condor. 94: 550-553.

Torgersen, Torolf R. 1997. Log resources and wildlife relationships. Portland,OR: U.S. Department of Agriculture, Forest Service, Pacific Northwest Research Station. 25 p. Unpublished data. On file with: Pacific Northwest Research Station, Forestry and Range Sciences Laboratory, 1401 Gekeler Lane, La Grande, OR 97850.

Torgersen, Torolf R.; Bull, Evelyn L. 1995. Down logs as habitat for forest-dwelling ants--the primary prey of pileated woodpeckers in northeastern Oregon. Northwest Science. 69: 294-303.

Urness, P.J. 1969. Nutritional analysis and in vitro digestibility of mistletoes browsed by deer in Arizona. Journal of Wildlife Management. 33: 499-505.
U.S. Department of Agriculture, Forest Service. 1995. Decision notice for the revised continuation of interim management direction establishing riparian, ecosystem and wildlife standards for timber sales. Portland, OR: U.S. Department of Agriculture, Forest Service, Pacific Northwest Region. 13 p.

U.S. Department of Agriculture, Forest Service. 1997. Current vegetation survey. Version 2.0. Portland, OR: U.S. Department of Agriculture, Forest Service, Pacific Northwest Region, Natural Resource Inventory. 115 p.

Wenger, Karl F., ed. 1984. Forestry handbook. 2 d ed. New York: John Wiley and Sons. 1335 p.

Wicker, Edward F.; Leaphart, C.D. 1974. Fire and dwarf mistletoe (Arceuthobium spp.) relationships in the northern Rocky Mountains. In: Proceedings, tall timbers fire ecology conference; tire and land management symposium; 1974 October 8-10; Missoula, MT. Tallahassee, FL: Tall Timbers Research Station: 279-298.

Wood, C.S.; Van Sickle, G.A.; Shore, T.L. 1985. Forest insect and disease conditions, British Columbia. Info. Rep. BC-X-259. Victoria, BC: Canada Forestry Service, Pacific Forest Research Centre. 32 p.

Wright, J.T.; Arrington, O.N. 1950. The cooperative Kaibab North livestock-deer forage relationship study. Phoenix, AZ: Arizona Game and Fish Department; Federal aid completion report project W-27-R-1,2, and 3. 223 p.

Ziller, Wolf G. 1974. The tree rusts of western Canada. Canadian Forestry Service Publ. 1329. Victoria, BC: Department of the Environment. 272 p. 


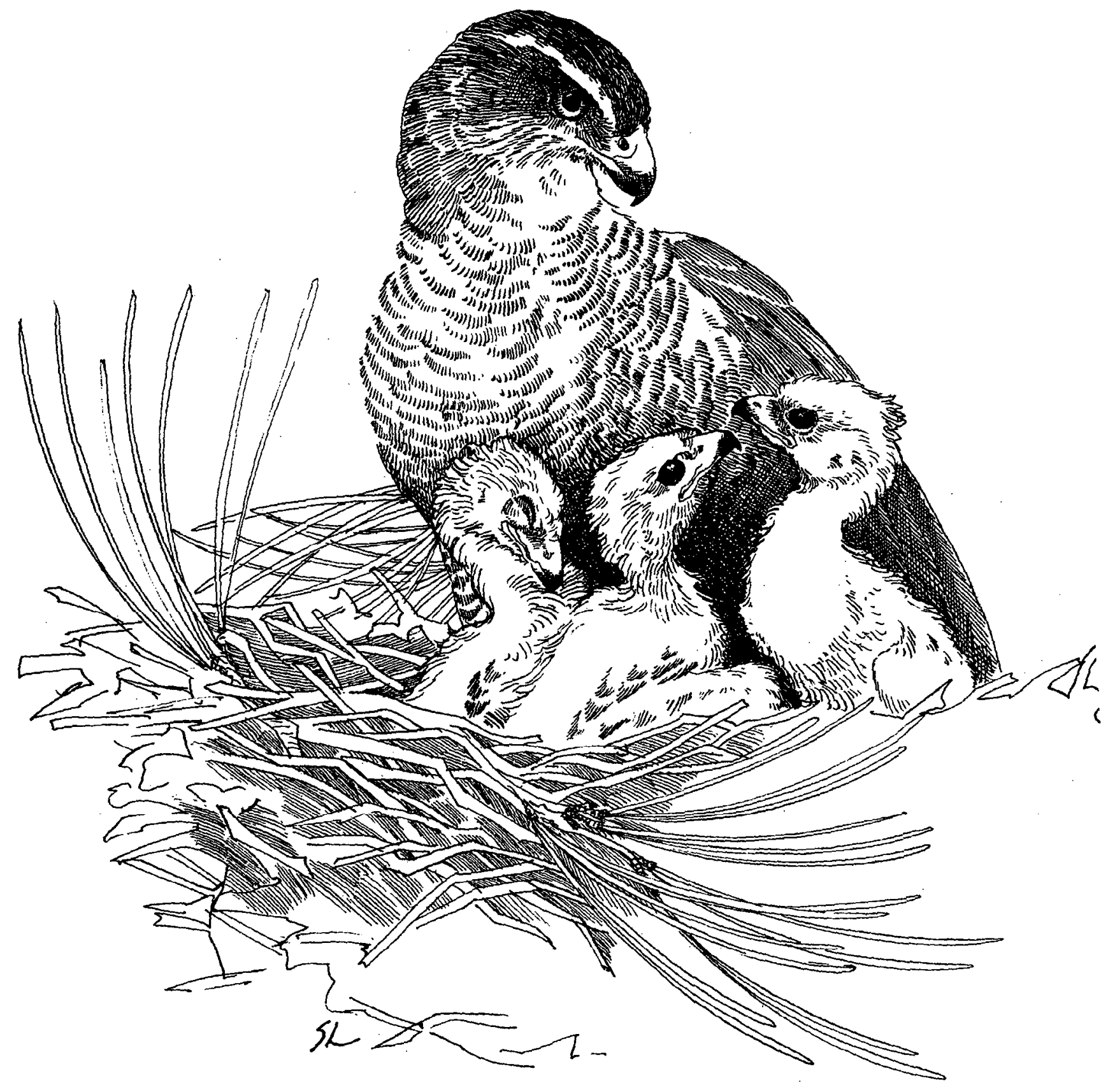




\section{MONITORING CREATED WILDLIFE TREES}

Forest or Location:

Monitoring Crew:

Stand or Area:

Contact Person:

Date of Treatment:

TREATMENT DATA

REMEASUREMENT DATA

\begin{tabular}{|c|c|c|c|c|c|c|c|c|c|c|c|c|c|c|}
\hline$T^{+\infty \pi \infty}$ & 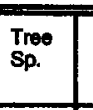 & 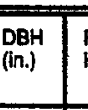 & 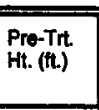 & $\begin{array}{l}\text { Treat } \\
\text { memm }\end{array}$ & 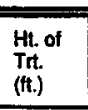 & GPS Poniss & 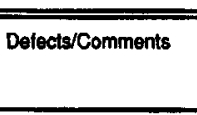 & 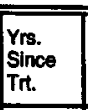 & 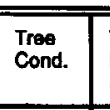 & 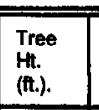 & 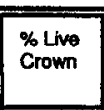 & $\begin{array}{l}\text { Fangos } \\
\text { usos }\end{array}$ & $\begin{array}{l}\text { Nost } \\
\text { Uose }\end{array}$ & Comments \\
\hline & & & & & & & & & & & & & & \\
\hline & & & & & & & & & & & & & & \\
\hline & & & & & & & & & & & & & & \\
\hline & & & & & & & & & & & & & & \\
\hline & & & & & & & & & & & & & & \\
\hline & & & & & & & & & & & & & & \\
\hline & & & & & & & & & & & & & & \\
\hline & & & & & & & & & & & & & & \\
\hline & & & & & & & & & & & & & & \\
\hline & & & & & & & & & & & & & & \\
\hline
\end{tabular}

Tree Species

$1=$ Pondersoa pine

$2=$ W. White phe

$4=$ Grand White

$5=$ W. larch

7 - W. hemlock

$8=$ W. red codar

9 - Aspen

10 - Cottonwood

$11=$ Birch
12 - Other

Treatments

$1=$ Dynamite top

$2=$ Sawn lop
$3=$ Inoculate

Tree Condition

$1=$ Live

Date of Remeasurement:

.1 Fungus

4 - Girdle

$5=$ Silvicide

Comments

(describe wildifie use;

= Broken

Whallie us

$1=$ Yes 


\section{Log Inventory}

Forest or Location:

Monitoring Crew:

Stand or Area:

Date:

Contact Person:

Stand History (burned, harvested, firewood cutting, insect/disease activity):

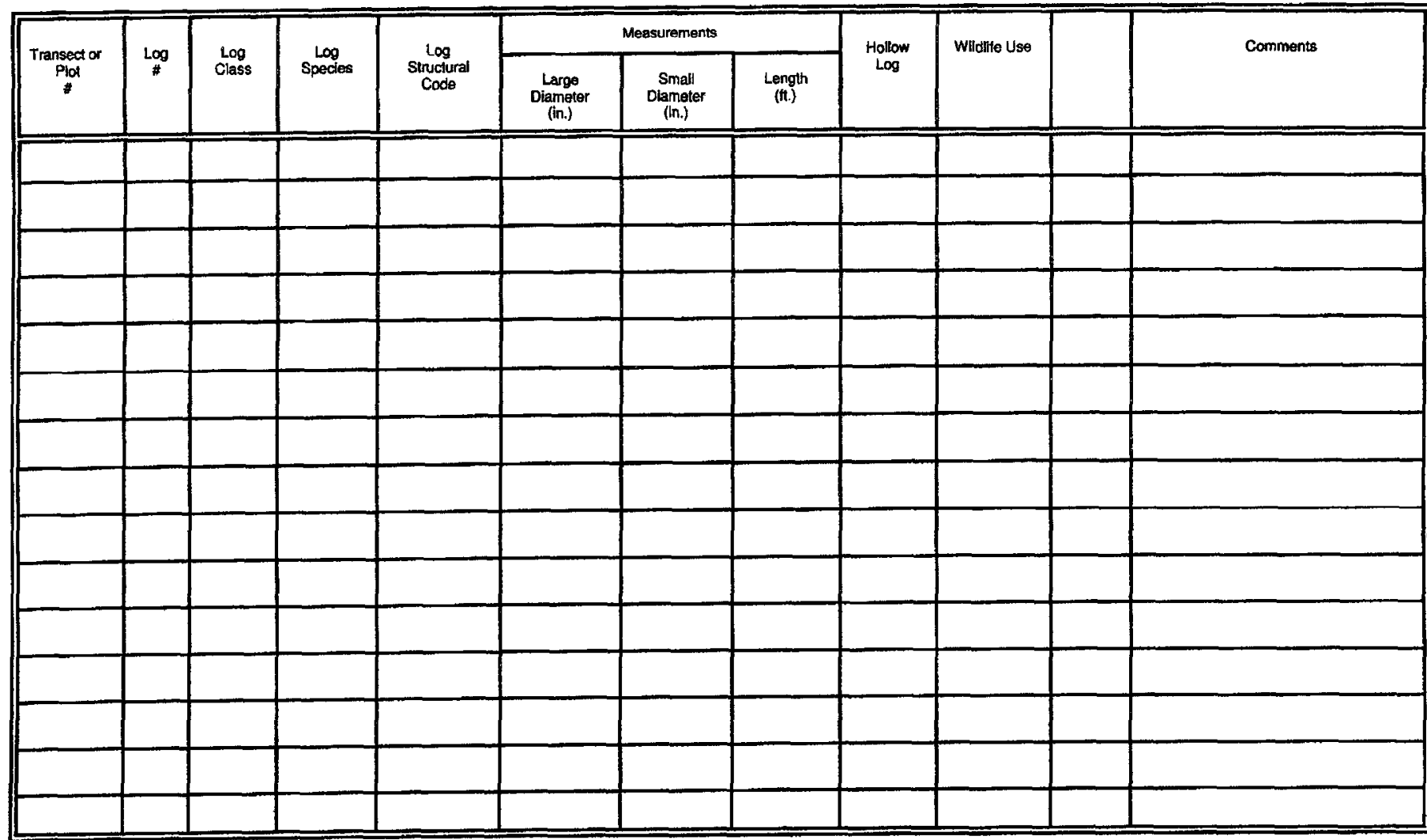

Log Glass

1=Natural $\log$ $2=$ Cut $\log$

$3=$ Natural log

$4=$ Cut Stump
Log Species

$1=$ Ponderosa pine

$2=W$. white pine

$3=$ Douglas-fir

$4=$ Grand White fir

$5=W$. larch

6=Lodgepole pine
Log Structural Code

1-3; PNW GTR

391, Figure $56 \& 57$

or

$10=$ Cottonwood

$11=$ Birch

$12=$ Other

1-5; Maser and
Measurements

Hollow 느g

Wildife Use

- Large diameter of log

is taken just above

butt-swell at "stump"

height.

"Use "length" column others (1979)

[circle one] to record height of

stump.

"Use "large diameter"

column to record

stump diameler.
$0=$ No
$1=$ Yes

$0=$ No excavations

$1.0^{\mathrm{N}}$ or larger in

diameter

$1=$ Woodpecker

foraging

(sapwood)

2=Woodpecker

Foraging

(heartwood)

3=Bear foraging

4-Bear den

$5=$ Squirrel cache

$6=$ Other 


\section{Appendix C}

\section{Methods for Log Inventories}

Line-transect method --The line-transect method is especially well adapted to sampling large areas or stands with varying topography and plant communities. For sample areas up to 30 acres, 18 plots each containing three 75 footlong transects (fig. 64A) will characterize log density within about 20 percent of the mean density of logs per acre. Such an array would contain a total of 4,500 linear feet of transect (three 75 -foot transects by 18 plots). Transects totalling 4,500 to 6,000 linear feet can be used to characterize a 30acre stand (Ottmar 1996). Larger areas might use proportionately longer totals for linear feet of transect.

Depending on the number of plots chosen, they may be placed at 66- to 198-foot intervals (1 to 3 chains) or more along a course in the sample area. The azimuths of the lines composing the course are chosen to ensure that plot centers fall at least one and one-half tree lengths within the margins of the stand. At each plot center, three radiating transects, $120^{\circ}$ apart, are established. For each plot, the azimuth of the first transect is selected from a random-number table or wristwatch (multiply seconds by 6 to get azimuth of first transect). Each succeeding transect is $120^{\circ}$ from the preceding one. The 75-foot transects are measured and marked by with a measuring tape. Crossing of transects from adjacent plots can be minimized by increasing the spacing between plot centers to more than 112 feet ( 2 chains).

An alternative method for laying out transects for log inventories is described in the Forest Service manual for Current Vegetation Survey (CVS). The layout for CVS incorporates five 51. 1-foot radii of subplots within the sample unit design (U.S. Department of Agriculture 1997).

All logs with a large-end diameter of 6 or more inches are tallied, without regard to what portion of the log is intercepted by the transect. A break-point diameter greater than the above 6-inch limit may be chosen depending on sizes of logs present, or specific purpose of the log inventory. This streamlines the sampling but will yield less information relevant to wildlife habitat.

Minimum data needed for each intercepted log are large-end diameter just beyond the butt swell, small-end diameter, and total length of log in feet. These measurements will permit computation of per-acre values for number of logs, volume, percentage of ground covered by logs, and linear feet of logs. One method for computing log volume is to use Smalian's formula (Wenger 1984) and to convert to cunits (CCFs). Other useful variables that may be recorded for each $\log$ are shown in the $\log$ inventory form (appendix B).
Number of logs per acre may be calculated by substituting total transect length and log lengths in equation 1 adapted from De Vries (1973) and Pickford and Hazard (1978), and applying constants to obtain pieces per acre where lengths of transects and logs are in feet:

$$
\mathrm{N}=((43,560 \times 3.1416) /(2 \times \mathrm{L})) \times\left(1 / \mathrm{a}_{1}+1 / \mathrm{a}_{2}, \ldots+\mathrm{l} / \mathrm{a}_{3}\right),
$$

where

$\mathrm{N}=$ number of logs per acre,

$\mathrm{L}=$ length of transect in feet, and

$\mathrm{a}=$ length of each $\log$ in feet.

Fixed-area plots-Circular or square plots of 1/40th-acre are a manageable size to sample. Areas of 20 to 30 acres can be characterized with 10 to 18 plots. Plots are established along sampling courses as described above for line transects. At each sample point, a random azimuth of 75-foot length is selected as above. The sample plot is laid out at the end of the transect. The end of the transect may be the center of a circular plot or a corner of a square plot (fig. 64B). Each log whose midlength falls within the boundaries of the plot is tallied. Log parameters as described for the line-transect method are recorded. Log density is calculated based on the 1/40th-acre plot size, that is:

$$
\text { Logs per acre }=\operatorname{logs} \text { per plot } \mathrm{x} 40 \text {. }
$$

With both line-transect and fixed-area plots, measures of variance may be obtained by using densities of logs for individual clusters of transects or plots to obtain SE's for mean densities over the sample area. Because larger logs generally provide better wildlife habitat, densities of logs by selected large-end-diameter classes and lengths may be more meaningful than density of logs per acre alone.

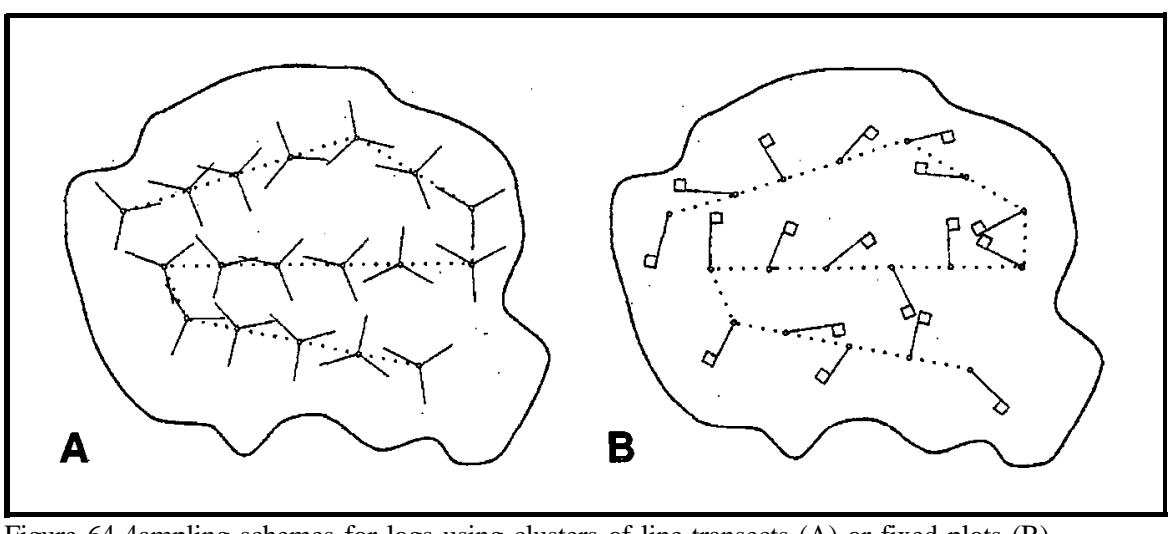

Figure 64-4ampling schemes for logs using clusters of line-transects (A) or fixed plots (B). 
Bull, Evelyn L.; Parks, Catherine G.; Torgersen, Torolf R. 1997. Trees and logs important to wildlife in the interior Columbia River basin. Gen. Tech. Rep. PNW-GTR-391. Portland, OR: U.S. Department of Agriculture, Forest Service, Pacific Northwest Research Station. 55 p.

This publication provides qualitative and quantitative information on five distinct structures: living trees with decayed parts, trees with hollow chambers, trees with brooms, dead trees, and logs. Information is provided on the value of these structures to wildlife, the decay or infection processes involved in the formation of these structures, and the principles to consider for selecting the best structures to retain.

Keywords: Broom rust, cavity nesters, decay fungi, dwarf mistletoe, Elytroderma, forest management, habitat monitoring, hollow trees, interior Columbia River basin, logs, old-growth forests, snags, wildlife, wood decay.

The Forest Service of the U.S. Department of Agriculture is dedicated to the principle of multiple use management of the Nation's forest resources for sustained yields of wood, water, forage, wildlife, and recreation. Through forestry research, cooperation with the States and private forest owners, and management of the National Forests and National Grasslands, it strives--as directed by Congress-to provide increasingly greater service to a growing Nation.

The United States Department of Agriculture (USDA) prohibits discrimination in its programs on the basis of race, color, national origin, sex, religion, age, disability, political beliefs, and marital or familial status. (Not all prohibited bases apply to all programs.) Persons with disabilities who require alternative means of communication of program information (Braille, large print, audiotape, etc.) should contact the USDA Office of Communications at (202) 720-2791 (voice), or (800) 855-1234 (TDD).

To tile a complaint, write the Secretary of Agriculture, U.S. Department of Agriculture, Washington, DC 20250 , or call (800) 245-6340 (voice), or (800) 8551234 (TDD). USDA is an equal employment opportunity employer.

Pacific Northwest Research Station 333 S.W. First Avenue

P.O. Box 3890

Portland, Oregon 97208-3890 
U.S. Department of Agriculture

Pacific Northwest Research Station

333 S.W. First Avenue

P.O. Box 3890

Portland, OR 97208-3890

Official Business

Penalty for Private Use, $\$ 300$

do NOT detach label 